
(C) Kent State University 2012. Duplication of the material contained herein is strictly prohibited without the express written consent of the Editor of The Journal of SPORT.

Cover created with copyrighted images by Cidepix licensed through us.Fotolia.com

ISBN-13 978-1477483589

ISBN-10 1477483586 


\section{Contents}

EMPLOYER WEAPONS IN LABOR-MANAGEMENT

RELATIONS: Are they Relevant (and Practical) in the Case of Labor-Management Disputes in Professional Sports

Hunter, Shannon and Mayo............................

Establishing a Strategic View of Sport Events: Marketing a Multiphase Sport Experience

Huberty and Ross...

An Examination of NCAA Division I Football Bowl

Championship Subdivision Department Revenues and

Expenditures and Their Effect on Athletic Success in a Mid-Major Athletic Conference

Ridpath, Fattlar and Yiamouyiannis....

The Fitness and Wellness IQ: Measuring College Student Learning in Campus Recreation Fitness and Wellness Programs

Milton, Roth, Porter, and Hutton

Division I Football Bowl Subdivision (FBS) Student-athlete perceptions on their NCAA postseason arrangement: A forcedchoice certainty method survey approach

Seifried and Turner....................................108

About The Journal of SPORT 

The Journal of SPORT, 2012, 1, 1-33

(C) Kent State University

\title{
EMPLOYER WEAPONS IN LABOR-MANAGEMENT RELATIONS: Are they Relevant (and Practical) in the Case of Labor-Management Disputes in Professional Sports?
}

Commissioner Roger Goodell stated with reference to the 2011 NFL lockout, "We haven't had any discussions or considerations of replacement players." He continued: "It's not in our plans." [March 22, 2011]

\author{
Richard Hunter \\ Seton Hall University \\ John Shannon \\ Seton Hall University \\ Ann Mayo \\ Seton Hall University
}

\begin{abstract}
What actions are permissible to an employer in a case of a labormanagement dispute? This article addresses the variety of options available to an employer in the context of a labor dispute, in general, and, in particular, in professional sports. Considered will be actions ranging from the hiring of replacement workers during a strike, the imposition of a full or partial lockout by the employer, the refusal of the employer to rehire workers who had been replaced during a strike, and whether the rules established for replacement workers equally apply where management has engaged in a lockout of its workers. A discussion of the importance of NLRB v. Mackay Radio and Telegraph Co. in the context of professional sports will be undertaken.
\end{abstract}




\section{INTRODUCTION TO ISSUES REGARDING EMPLOYEE REPLACEMENTS}

Consider this scenario. Players on the South Bend, Indiana, Femi Yankees, a team in the United States Women's Professional Frisbee League [USWPFL], go on strike against their employer when the League and the union representing players fail to reach an agreement on the contract by the start of the 2012 Professional Frisbee Season. The Femi Yankees, contemplating financial ruin if the season doesn't begin (having spent thousands of dollars on a brand-new, indoor Astroturf field complex that seats 12,000), decide to begin the season with replacement players. After a five week strike by the players, followed by a five week lockout by team management, the league manages to reach agreement with its union and eight players of the twelve who had been replaced seek reinstatement. The Femi Yankees refuse to accept the striking players back and the players seek the assistance of the local NLRB to reclaim their jobs.

In the field of labor-management relations, the employer is often placed at a disadvantage if a strike results in the closing of the workplace. In order to protect its business interest by remaining open, an employer may decide to hire replacement workers. The same reality exists in the context of professional sports - but with a variety of quite different considerations than exist in a typical "nonsports" workplace environment. While it is a separate question whether such a strategy will be successful in a practical sense, given the realities of the market structure, fan acceptance of replacement players, ${ }^{1}$ and ticketing policies of professional sports, ${ }^{2}$ the legal

11 See James R. Devine, The Legacy of Albert Spalding, the Holdouts of Ty Cobb, Joe DiMaggio, and Sandy Koufax/Don Drysdale, and the 1994-95 Strike:

Baseball's Labor Disputes are as Linear as the Game, 31 AKRON L. REV. 1 (1997) (citing John Lowe \& Gene Guidi, Who the Heck Are These Guys? Prepare for Replacements- And Some Bad Baseball, DETROIT FrEE PRESS, Feb. 27, 1995, at Sports 1D and noting comments by then-acting MLB Commissioner Bud Selig, "It is far from a perfect solution. Nobody knows that better than me. It's just fulfilling the need to play."). See also Mark Maske, Relief Is All Too Comic: Replacements are a Far Cry from Major Leaguers, WASHINGTON POST, Feb. 26, 
issues are still important from the standpoint of the broader context of labor-management relations in the United States.

\section{Mackay: The Hiring of Replacement Workers}

1995, at Sports D11. On the practical side, Lattinville, Boland \& Speyer, in addressing the conundrum, have noted:

Professional athletes are some of the highest-skilled workers in the world. They possess natural physical abilities, honed by years of practice, which cannot be easily duplicated with mere hard work or good fortune. Owners of professional sports franchises, even when faced with the revenue losses that may accompany a strike or lockout, rarely consider using temporary or permanent replacements.

Robert H. Lattinville, Robert A. Boland \& Bennett Speyer, Labor Pains: The Effect of a Work Stoppage in the NFL on its Coaches, 20 MARQ. SPORTS L. REV. 335,345 (2010).

2 See, e.g., Grant M. Hayden, Some Keys to the NBA Lockout, 16 HofSTRA LAB. \& EMP. L.J. 453 (1999):

And though replacement players were used for three games during the 1987 professional football strike, the effort was not very successful, and probably only possible because football players, with the exception of star players in the skill positions, are relatively anonymous in comparison to their counterparts in baseball, basketball, and hockey. Professional athletes operate in what is essentially a closed labor market, which gives them a tremendous advantage over their counterparts in other occupations.

See also Murray Chass, As Trade Unions Struggle, Their Sports Cousins Thrive, N.Y. TIMES, Sept. 5, 1994, at 1.

It is interesting to note that after originally telling Congress that baseball fans would be given the option to get a full refund of season tickets if replacement players were used - without losing rights to future seats - the Commissioner's office later indicated that this was not a major league policy and that this decision would be left to individual clubs. See First-Pitch Replacements for Clinton, Detroit FreE PRESS, Feb. 17, 1995, at Sports 5C. 
The often discussed and much maligned case of $N L R B v$. Mackay Radio \& Telegraph ${ }^{3}$ provides an interesting insight into the practices and practicalities hiring replacement workers. ${ }^{4}$ A brief discussion and review of the case is in order.

Following the failure of negotiations to come to an agreement with respect to the terms and conditions of employment, employees of Mackay Radio \& Telegraph, a company engaged in the transmission and receipt of radio, telegraph, and cable messages - both interstate and foreign - went on a strike. In order to keep its business in operation, the company brought employees from its offices in other cities to take the places of the strikers. After the strike ended, all but five of those who had been on strike were taken back into the employ of the company. These five employees then sought reinstatement. A proceeding was initiated before the National Labor Relations Board [NLRB] upon a complaint against the company charging that Mackay's refusal to re-employ the five was a discrimination against them based on their union activities and that the company was guilty of unfair labor practices [ULPs] under the National Labor Relations Act [NLRA]. ${ }^{5}$ After a hearing, and

3304 U.S. 333 (1938).

${ }^{4}$ For a general critique of the ruling in Mackay, and the inclusion of dictum as, in effect, the holding of the case, see James Gray Pope, How American Workers Lost the Right to Strike, and Other Tales, 103 MICH. L. REv. 518, 533-34 (2004).

${ }^{5}$ Pub.L. $74-198,49$ Stat. 452, codified as amended at 29 U.S.C. $§ 151-169$ (1994). Three sections of the NLRA are especially relevant. Section 8(d) of the NLRA mandates a duty to bargain collectively in good faith. Section 8(a)(1) declares it an unfair labor practice for employers to prevent employees from exercising their rights given to them under Section 7 of the NLRA. Section $8(a)(5)$ declares it an unfair practice for employers to refuse to bargain collectively with employees. In NLRB v. Major League Baseball, the Players Association had maintained, and the Administrative Law Judge agreed, that the owners' decision to break off negotiations and to insert replacement players violated Sections 8(a)(1) and (5) of the NLRA. See NLRB v. Major League Baseball, 880 F. Supp. 246, 252 (S.D.N.Y. 1995).

As Professor Boucher noted: 
upon findings of fact and conclusions of law, the Board ordered Mackay Radio to cease and desist from discharging or threatening to discharge any of its employees because of their membership in the union or on account of protected union activities; to refrain from interfering with, restraining or coercing its employees in respect of self-organization and collective bargaining; required the company to reinstate to their former positions the five men who had not been reemployed with back pay; and to post notices to the effect that members of the union would not be discriminated against in the future.

The case eventually reached the United States Supreme Court on appeal. A summary of the holding of the Court reveals the following:

- Under the findings, the strike was a consequence of, or in connection with, a "labor dispute" as defined in section 2(9) of the National Labor Relations Act. The Board was not

Although not addressed in the court's opinion, by forcing both sides back to the bargaining table, the court decided that an impasse in negotiations had not occurred. By not addressing this issue, it can only be concluded that the court decided an impasse was not possible. If an 'impasse' in negotiations was reached, the owners would have been free to initiate unilateral changes, such as inserting replacement players. Because the owners failed to bargain in good faith by unilaterally changing a mandatory subject of the bargaining agreement (players salaries/salary cap), an impasse was impossible. This struck a final blow against the owners' attempt to take back the control they lost when the reserve clause was eliminated and demonstrated the strength the Players Association had gained as a labor organization by enforcing its rights under the NLRA.

Gregory Boucher, Baseball, Antitrust and the Rise of the Players' Association, 4 U. DENV. SPORTS \& ENT. L.J. 121, 133-35 nn.75-77 (2008). 
required to find what the state of the negotiations was when the strike was called, nor that a "labor dispute" existed. ${ }^{6}$

- Their work having ceased as a consequence of, or in connection with, a current labor dispute, under section 2(3), the strikers remained "employees" of the company for the purposes of the Act, and were thus protected against any unfair labor practices prohibited by the Act. ${ }^{7}$

- Discrimination in reinstating employees who had been on strike by excluding certain of them for the sole reason that they had been active in the union was an unfair labor practice prohibited by section 8 of the Act. ${ }^{8}$

- However, it was not an unfair labor practice for the company to replace its striking employees with other employees in an effort to carry on the business; nor was the company bound later to discharge other employees in order to reinstate the strikers. ${ }^{9}$

In sum, as to the core issue of the replacement of the five employees, the Court concluded:

Nor was it an unfair labor practice to replace the striking employees with others in an effort to carry on business. Although section 13 provides "Nothing in this Act (chapter) shall be construed so as to interfere with or impede or diminish in any way the right to

6 Mackay, 304 U.S. at 344.

7 Id. at 345 .

8 Id. at 346.

9 Id. at 345. In a related matter, after the cancellation of its 2004-2005 season, the NHL was considering the possibility of using replacement players for the 20052006 season. Under the NLRA, it would have been possible, in accordance with a complex legislative mechanism, to use replacement workers, or "scabs" in the case of a deadlock in negotiations. See 29 U.S.C. $§ 158$. 
strike," it does not follow that an employer, guilty of no act denounced by the statute, has lost the right to protect and continue his business by supplying places left vacant by strikers. And, he is not bound to discharge those hired to fill the places of strikers, upon the election of the latter to resume their employment, in order to create places for them. ${ }^{10}$

\section{DEVELOPMENTS SINCE MACKAY}

Returning to the context of professional sports, ${ }^{11}$ it is interesting to note that NFL Commissioner Roger Goodell stated with reference to the 2011 NFL lockout, "We haven't had any discussions or considerations of replacement players." $\mathrm{He}$ continued: "It's not in our plans." ${ }^{12}$ This statement, however; begs

${ }^{10}$ Mackay, 304 U.S. at 345-46 (emphasis added).

11 An interesting compilation of the ten most significant professional sports' strikes and/or lockouts has been provided by Josh Tinley. These include (in reverse order):

- 1992 NHL players strike

- 1984 Association of Volleyball Professionals strike

- 1981 Major League Baseball players strike

- 1979 Major League Baseball umpires strike

- 1998-99 NBA lockout

- 1994-95 NHL lockout

- 1982 NFL players strike

- 1987 NFL players strike

- $\quad$ 1994-95 Major League Baseball players strike

- 2004-05 NHL lockout

See Josh Tinley, The 10 Most Significant Pro Sports Strikes and Lockouts, Oct. 13, 2011, at www.midwestsportsfans.com.

12 Alex Marvez, NFL Not Planning on Replacement Players, March 22, 2011, at msn.foxsports.com. 
the larger question whether the use of replacement employees (in this case: players) in a case where the employer has locked out the employees or where the workers have engaged in a strike action is permissible? This article begins with a discussion of replacement workers [players] in the context of a strike and will return to the issue once again in the context of an employer [league-wide] lockout.

Several developments since the Supreme Court decided Mackey are relevant to the determination of this question and to a further refinement of the practice in the case of a strike. ${ }^{13}$

The situation in the general labor market, while not containing many of the practical problems associated in arena of professional sports, changed markedly during the 1980s in the United States as the American economy suffered from the twin economic inefficiencies of recession and burgeoning deindustrialization. ${ }^{14}$ Deindustrialization, in fact, began in the United States, with the share of manufacturing employment falling from a peak of 28 percent in 1965 to only 16 percent in 1994 . $^{15}$ The 1980s also saw the use of permanent replacements in order to break

13 See generally Grant M. Hayden, Some Keys to the NBA Lockout, 16 HOFSTRA LAB. \& EMP. L.J. 453 (1999).

14 Professors Golden and Fazili note: "The 1980s saw the rise of neoliberal economic policies, leading to a flight of well paying manufacturing jobs, increased worker insecurity, and stagnating real wages." Robin S. Golden \& Sameera Fazili, The Worst of Times: Perspectives on and Solutions for the Subprime Mortgage Foreclosure Crisis: Raising the Roof: Addressing the Mortgage Foreclosure Crisis Through Collaboration Between City Government and a Law School Clinic, 2 AlB. Gov'T L. REV. 29, 56 (citing Carl H. Nightingale, Globalization and Deindustrialization, in POVERTY IN THE UNITED STATES: AN ENCYCLOPEDIA OF History, Politics, \& POLICY 345, 347-50 (Gwendolyn Mink \& Alice O'Connor eds., 2004)). Of course, none of these were considerations in the continued growth of professional sports during this same period-indicating that professional sports was virtually immune from the consequences of general deindustrialization that gripped the United States.

15 Robert Rowthorn \& Ramana Ramaswamy, Deindustrialization-Its Causes and Implications, Sept. 1997, at www.imf.org/external/pubs/ft/issues10. 
unions in a number of very high-profile labor disputes, perhaps the most notable of which was the Reagan Administration firing of hundreds of striking air traffic controllers in $1981 .^{16}$ Just two years

16 See, e.g., Herbert Northrup, The Rise and Demise of PATCO, 37 InDUS. \& LAB. REL. REV. 167 (1984). On August 3, 1981 nearly 13,000 of the 17,500 members of the Professional Air Traffic Controllers Organization (PATCO) walked off the job. Their stated purpose was to effect a major disruption of the nation's transportation system in order to put pressure on management (the United States government) to secure agreement to their demands. President Reagan responded almost immediately with an ultimatum: return to work within 48 hours or face immediate termination. As are all federal employees, the air traffic controllers were in violation of a "no-strike" clause of their employment contracts. The union was demanding an across-the-board wage increase of $\$ 10,000 / \mathrm{yr}$ for controllers, whose pay ranged from $\$ 20,462$ to $\$ 49,229$; the reduction of a five-day, 40-hour work week to a four-day, 32-hour work week; and full retirement after 20 years service. The government estimated that the package would cost taxpayers $\$ 770$ million. The Federal Aviation Administration [FAA], PATCO's adversary in the collective bargaining process, made a $\$ 40$ million counteroffer, which included a shorter work week and a 10 percent pay hike for night shifts and for those controllers who doubled as instructors. However, when the contract offer was submitted to the membership, 95 percent of PATCO's membership rejected the final settlement. Upon this rejection, the FAA began work on a contingency plan that would go into effect if a strike occurred in order to assure that air traffic would not adversely affected.

The impact on the American economy was both real and immediate. Jason Manning reports that by the 1980s, air transportation was a $\$ 30$ billion-ayear business - every day 14,000 commercial flights carried 800,000 passengers, with 10,000 tons of air cargo transported daily. American carriers employed 340,000 people. From the outset, public support for the strikers was minimal. In fact, it seemed that the American public sided with the government and "exhibited little sympathy for individuals whose earnings were already well above the national average." The government took decisive steps to end the strike and to punish its ringleaders. The Department of Justice indicted seventy-five controllers. Federal judges levied fines amounting to $\$ 1$ million a day against the union for every day that the strike lasted. Finally, more than 11,000 strikers were terminated. In October, the Federal Labor Relations Authority (FLRA) decertified PATCO. See Jason Manning, The Air Traffic Controller's Strike (2000), at www.eightiesclub.tripod.com/id296.htm (last visited Jan. 18, 2012). See also Joseph McCartin, Collision Course: Ronald Reagan, The Air TrafFiC Controllers, AND the Strike THAT CHANGED AmERICA (2011) (arguing that 
the fall of PATCO's ushered in a sustained period of labor decline and as an indication of the campaign against public sector unions).

The requirements for decertification of a union are (1) at least a year must have passed since the employees elected or the employer recognized the union (the so-called "one year bar rule"), and (2) there must not be a collective bargaining agreement in effect (though employees may file a decertification petition in a brief window between 90 and 60 days before the expiration of the collective bargaining agreement in most industries and between 120 and 90 days in the case of a health care institution). See $\S 9(\mathrm{c})(3), 29$ USC $\S 159(\mathrm{c})(3)$; General Cable Corp, 139 N.L.R.B. 1123, 1124-25 (1962) (stating the "contract bar" rule). Section 9(c)(1), which regulates action on petitions to the NLRB, provides:
Whenever a petition shall have been filed, in accordance with such regulations as may be prescribed by the Board--(A) by an employee or group of employees or any individual or labor organization acting in their behalf alleging that a substantial number of employees ... (ii) assert that the individual or labor organization, which has been certified or is being currently recognized by their employer as the bargaining representative, is no longer a representative as defined in Section 9(a) . . . the Board shall investigate such petition and if it has reasonable cause to believe that a question of representation affecting commerce exists shall provide for an appropriate hearing upon due notice. ... If the Board finds upon the record of such hearing that such a question of representation exists, it shall direct an election by secret ballot and shall certify the results thereof.

\section{USC $\S 159(c)(1)$.}

The process of decertification is rather a simple one. At least 30 percent of the employees represented by a union must sign either a petition or individual [authorization] cards asserting that they no longer want to be represented by the union. The petition is filed with the NLRB. The NLRB will verify the validity of the petition and will schedule an election. If the union receives 50 percent or less of the votes in this election, decertification of the union is complete. See 29 USC $\S$ 159.

In addition, notes Catherine Meeker: 
after PATCO, another strike that had attracted national attention was broken at the Phelps Dodge refinery in Arizona. The matter was resolved when the workforce was essentially deunionized. ${ }^{17}$ A third

\begin{abstract}
Also, even while a collective bargaining agreement is in effect, an employee-initiated petition for decertification signed by the majority of the employees may oust the union. While invalid as a means of directly removing the union, the petition may be used by the employer as evidence that he has a good faith doubt of the union's continuing majority status that justifies his withdrawal of recognition for the negotiation of future agreements. Indeed, the employer may stop bargaining even before a petition is filed or granted if he has a reasonable belief that a majority of the workers no longer wish to be represented by the union.
\end{abstract}

Catherine Meeker, Defining "Ministerial Aid”: Union Decertification Under the NLRA, 66 U. CHI. L. REV. 999, 1001 n.5 1999 (citing Vic Koenig Chevrolet, Inc v NLRB, 126 F.3d 947, 948 (7th Cir 1997); Rock-Tenn Co v NLRB, 69 F.3d 803, 808 (7th Cir 1995)).

17 See, e.g., JONATHAN Rosenblum, COPPER CRUCIBLE: HOW THE ARIZONA MINERS' STRIKE OF 1983 RECAST LABOR MANAGEMENT RELATIONS IN AMERICA (1998).

On April 7, 1982, Phelps Dodge announced that it would lay off 3,400 of its workers in operations in Texas and Arizona. In May 1983, it began negotiations with the United Steelworkers and other unions in Phoenix, Arizona. The unions agreed to make a series of concessions, including freezing members' wages for three years. The union, however, continued to insist on a Cost of Living Adjustments (COLA) and to other measures designed prevent job combinations that would result in a loss of employment for many of its members. These demands were in line with agreements which had been accepted by other major mining corporations, including Kennecott, Asarco, Magma Copper, and Inspiration Consolidated Copper. However, the management of Phelps Dodge maintained that it was facing intense competition from overseas producers and could not enter into similar agreements.

The subsequent collective bargaining negotiations with the unions failed to produce an agreement. On midnight of July 30, a strike began, which included workers from operations in Morenci, Ajo, Clifton, and Douglas, Arizona. A picket line appeared at the Morenci Mine in Arizona. The next day, Phelps Dodge 
reacted by increasing security in and around the mine. Miners were later subjected to what were characterized as unlawful arrests, firings, evictions, and undercover surveillance by the Arizona Criminal Intelligence Systems Agency. See Arizona Copper Mine Strike of 1983, www.connexions.org/.../Docs/CxPArizona_Copper_Mine_Strike_of_1983.htm.

At the beginning of August, Phelps Dodge announced that they would be hiring permanent replacement workers for the striking workers at the Morenci Mine. Phelps Dodge took out many large ads seeking new workers in newspapers in both Tucson and Phoenix. Interestingly, the local government, in obvious support of a major area employer, sought and obtained injunctions which limited both picketing and demonstrations at the mine.

The situation reached a seeming crescendo when, on Monday, August 8, approximately 1,000 strikers and their supporters gathered at the gate to the mine in response to both company and local governmental actions. Phelps Dodge stopped production and, later that day, Arizona Governor Bruce Babbitt, a "liberal" Democrat generally regarded as being friendly to union concerns, flew in to meet with company representatives. Phelps Dodge agreed to a 10-day moratorium on hiring replacement workers. The company and its union counterparts also agreed that a federal mediator would be called in for any future negotiations. [The Labor-Management Relations Act of 1947, better known as the "Taft-Hartley Act," established the Federal Mediation and Conciliation Service, with the purpose of assisting management and labor in resolving disputes through the introduction of a federal mediator. See 61 Stat. 153, 29 U.S.C.A. $§ 172$ (1947)].

Despite these conciliatory efforts, on the morning of August 19, "military vehicles, tanks, helicopters, 426 state troopers and 325 National Guard members arrived in Clifton and Morenci as part of 'Operation Copper Nugget' to break the strike.” See Arizona Copper Mine Strike of 1983, www.connexions.org/.../Docs/CxP-Arizona_Copper_Mine_Strike_of_1983.htm.

Governor Babbitt had turned out not to be the friend labor expected! Strikers, who were manning the picket lines at the main gate, were unsuccessful in preventing the replacement workers from entering the mine. On August 27, 10 strikers were arrested in Ajo and charged with rioting. It became apparent that the strike had lost much of its momentum. The strike continued, but the introduction of replacement workers clearly changed the dynamics of the controversy. The strike officially ended on February 19, 1986, when the National Labor Relations Board rejected appeals from the unions who were attempting to halt decertification 
case of the use of replacement workers occurred at the Hormel meat packing plant in Austin, Minnesota - an actions that resulted in hundreds of strikers losing their jobs. ${ }^{18}$

based upon the fact that the union could no longer count on a representation majority in the workplace.

18 See Peter RachlefF, Hard-Pressed in the HeARTland: The Hormel STRIKE AND THE FUTURE OF THE LABOR MOVEMENT (1993).

In August 1985, workers at the Hormel corporate headquarters in Austin, Minnesota, went on strike. In the early 1980s, the twin issues of recession and deindustrialization began to impact on the meatpacking industry, forcing several companies to go out of business. Others stayed in business - just barely-by either declaring bankruptcy or severely reducing workers' benefits and wages. When Hormel management demanded a 23\% wage cut from its 1,500 workers, the workers decided to strike. The strike was called with the support of the local of the United Food and Commercial Workers [UFCW], $P-9$ - but without the support of the international or parent union. The strike gained national attention and led to a widely publicized boycott of Hormel products.

As the strike wore on, a significant number of strikebreakers crossed the picket line, provoking what were termed as riots in the city of Austin. On January 13, 1986, Hormel opened the plant to scabs - the term often used by union supporters to describe those who crossed the picket line to work. On January 21, 1986, Rudy Perpich, the Democratic Governor of Minnesota, called out the Minnesota National Guard in order to protect the strikebreakers. This brought protests against the governor's actions, and the National Guard was withdrawn from Austin. In March, the UFCW international ousted the local leadership of the local P-9 by placing the local under trusteeship and declaring the strike over.

The strike officially ended in June 1986, after lasting 10 months. As a result, over 700 of the workers did not return to their jobs, refusing to cross the picket line. In the end, however, Hormel succeeded in hiring replacement workers at significantly lower wages. By the fall of 1986, a radically different union ratified the terms of the new contract. See Erin Galbally, Nearly 20 years later, the Hormel strike lives on, Jan. 29, 2004, at news.minnesota.publicradio.org/.../2004/01/29_galballye_hormelstrike.

Peter Rachleff reported that: 
In 1987, a strike resulted in the total replacement of striking workers at the International Paper Company in Jay, Maine. ${ }^{19}$ Implications of Mackay: Firing Strikers vs. Permanent Replacements

In the legal context, there are several important distinctions between firing employees who are on strike, an action prohibited by law, and permanently replacing them, a practice permitted under Mackay. There are three important considerations present in this dichotomy. ${ }^{20}$ First, strikers do not technically lose their jobs until their replacements are in fact actually hired. Indeed, until a replacement worker has actually been hired, an employer may not inform a striking worker that he or she has been replaced. It is also improper for an employer to refuse to reinstate a striking employee who has made an "unqualified" offer to return to work. Second,

\begin{abstract}
Local P-9 was ultimately defeated by an array of powerful forces: corporate obstinacy, an ability to shift production to other plants and support from other business interests including those banks; a series of hostile court decisions and injunctions; the intervention of the Minnesota National Guard, under orders from Governor Rudy Perpich; an unsympathetic media and its own international union, which was supported by a labor bureaucracy at the highest reaches of the state's and the nation's unions.
\end{abstract}

Peter Rachleff, Hormel Strike key to nation's labor history, Aug. 23, 2010, at finance-commerce.com/2010/08/hormel-strike-key-to-nations-labor-history.

19 See, e.g., Julius Getman, The Betrayal of Local 14 (1998). See also Michael H. LeRoy, Severance of Bargaining Relationships During Permanent Replacement Strikes and Union Decertifications: An Empirical Analysis and Proposal to Amend Section 9(c)(3) of the NLRA, 29 U.C. DAVIS L. REV. 1019, 1051-69 (1996). International Paper, a company that amassed record profits and gave generous bonuses to corporate executives in 1987, demanded that its employees agree to a substantial cut in wages, agree to sacrifice hundreds of jobs, and forego many paid holidays - including Christmas. At the Adroscoggin Mill in Jay, Maine, twelve hundred workers responded by going on strike that extended from June 1987 to October 1988. Eventually, International Paper brought in permanent replacement workers and the strike was ultimately abandoned.

20 Adapted from KenNETH G. DAU-SCHMIDT, Et Al, LABOR LAW IN THE CONTEMPORARY WORKPLACE 614-15 (2009). 
according to NLRB procedures, a striking worker who has been replaced will retain the right to vote in any union election for a period of one year from the date the strike begins. ${ }^{21}$ Third, under the NLRB's decision rendered in Laidlaw Corp. ${ }^{22}$ a permanently replaced striker has a qualified right to reinstatement when vacancies again become available. ${ }^{23}$

Laidlaw contains a number of interesting points that greatly impact on the issue of replacing striking workers. Under Laidlaw, a striking worker seeking reinstatement must make what is termed as an "unconditional offer" to return to work and may not have "abandoned the employ [of the employer] for substantial and equivalent employment." 24 Once a striker makes such an offer to unconditionally return to work, it is then "incumbent on [the employer] to seek them out as positions [are] vacated." 25 An

\footnotetext{
21 "Employees engaged in an economic strike who are not entitled to reinstatement (because they have been replaced, etc.) shall be eligible to vote under such regulations as the Board shall find are consistent with the purposes and provisions of this subchapter in any election conducted within twelve months after the commencement of the strike." (parenthetical statement added in the original). See C.H. Guenther \& Son, Inc. v. NLRB, 427 F.2d 983 (5th Cir.), cert. denied, 400 U.S. 942 (1970) (enforcing a Board order based upon section 159(c)(3)).
}

${ }^{22}$ NLRB v. Laidlaw Corp., 171 N.L.R.B. 1366 (1968).

${ }^{23}$ Id. at 1369-70. The violations of the National Labor Relations Act which the Board found were: section 8(a)(1), by threatening to deny employment forever to its employees if they struck and were replaced and by maintaining an invalid nodistribution rule; and section 8(a)(3) and (1), by failing and refusing to offer a replaced striker full reinstatement to his former job, by terminating the employment status of a large number of other replaced strikers following their unconditional offer to return to work, and by later failing and refusing to offer them reinstatement. The Board's order was enforced by the Seventh Circuit Court of Appeals in Laidlaw Corp. v. NLRB. 414 F.2d 99 (1969).

${ }^{24} I d$. 
employer may counter such a request to be reinstated by offering the justification that the striking work does not then possess the skills necessary to fulfill the requirements for the job as it is presently constituted. $^{26}$ Any striker who is entitled to reinstatement under Laidlaw must be reinstated with full seniority, but a worker's seniority may not be used to get a preferred job or any preferable shift assignment. $^{27}$

After the Hormel strike was resolved to the disadvantage of its workers when the company hired permanent replacement workers, the Minnesota state legislature reacted by enacting a statute that banned the use of permanent replacements. However, in Employers Ass' $n$ v. United Steelworkers, ${ }^{28}$ the court of appeals declared that federal labor law, as expressed in Mackay, preempted state striker replacement law. The court of appeals noted that the

26 See also NLRB v. Fleetwood Trailer Co., 389 U.S. 375 (1967). In Fleetwood, the Supreme Court said that "unless the employer who refuses to reinstate strikers can show that his action was due to 'legitimate and substantial business justifications,' he is guilty of an unfair labor practice." $I d$. at 378 . The Court went on to observe that in some situations, "legitimate and substantial business justifications for refusing to reinstate employees who engaged in an economic strike have been recognized. One is when the jobs claimed by the strikers are occupied by workers hired as permanent replacements during the strike in order to continue operations." Id. at 379. This rule is often termed the "business justification" rule.

${ }^{27}$ See Trans World Airlines, Inc. v. Independent Federation of Flight Attendants, 489 U.S. 426 (1988) (holding that an employer is not required by the Railway Labor Act to lay off junior crossover employees in order to reinstate more senior full-term strikers at the conclusion of a strike). The Supreme Court held that "TWA's decision to guarantee to crossovers the same protections lawfully applied to new hires was a decision to apply the pre-existing seniority terms of the collective bargaining agreement uniformly to all employees. That this decision had the effect of encouraging prestrike workers to remain on the job during the strike or to abandon the strike before all vacancies were filled was simply an effect of TWA's lawful exercise of its peaceful economic power." Id. at 443.

2832 F.3d 1297 ( $8^{\text {th }}$ Cir. 1994). 
district court had found that the Minnesota law violated principles of preemption enunciated in Machinists $v$. Wisconsin Employment Relations Committee ${ }^{29}$ because the Minnesota Striker Replacement Law interfered with an area which Congress had intended to leave essentially unregulated. The district court also indicated that the statute failed under the seminal case of San Diego Building Trades Council v. Garmon. ${ }^{30}$

It may be interesting to note that when President Clinton attempted to intervene in the larger controversy by issuing an Executive Order ${ }^{31}$ banning the use of permanent replacement workers by government contractors, the matter once again wound up

${ }^{29} 427$ U.S. 132 (1976) (prohibiting state and municipal regulation of areas that have been left to be controlled by the free play of economic forces, preserving Congress' intentional balance between the uncontrolled power of management and labor to further their respective interests).

30359 U.S. 236 (1959) (forbidding state and local regulation of activities that are "protected by Sec. 7 of the [NLRA], or constitute an unfair labor practice under Sec. 8"). Garmon pre-emption prohibits regulation even of activities that the NLRA only arguably protects or prohibits. However, in a related case, where an employer had promised replacement workers that they would be made permanent, the employer terminated them in order to make room for reinstated strikers. The case filed by the replacement workers, based on state claims of misrepresentation and breach of contract, were held not to be preempted. See Belknap v. Hale, 463 U.S. 491 (1983).

31 President Clinton issued Executive Order No. 12,954, 60 Fed. Reg. 13,023 (1995), on March 8, 1995, pursuant to his authority under the Federal Property and Administrative Services Act, 40 U.S.C. $§ 471$ et seq. (the Procurement Act), which declares:

It is the policy of the executive branch in procuring goods and services that, to ensure the economical and efficient administration and completion of Federal Government contracts, contracting agencies shall not contract with employers that permanently replace lawfully striking employees.

Order at $13,023, \S 1$. 
in court. In Chamber of Commerce v. Reich, ${ }^{32}$ the D.C. Circuit held that the NLRA preempted the Executive Order because the use of permanent replacement workers was a right that was now firmly guaranteed under the NLRA.

74 F.3d 1322 (D.C. Cir. 1996). Upon a petition for a rehearing, the court of appeals stated:

But, it does prevent any government action-certainly any action by a government entity other than the NLRB interpreting the NLRA-that is predicated upon (implicitly or explicitly) a substantive policy view as to the appropriate balance of bargaining power between organized labor and management and that attempts to promote a governmental objective by a generic shift in that balance. Such an action is 'regulatory' within the meaning of Machinists 'preemption.'

83 F.3d 439, 441 (D.C. Cir. 1996) (citing Machinists, 427 U.S. at 143-44, 149-50). The Court of Appeals also stated: "Almost 60 years ago, the Supreme Court explained that an employer retained the right "to protect and continue his business by supplying places left vacant by strikers. And he is not bound to discharge those hired to fill the places of strikers, upon the election of the latter to resume their employment, in order to create places for them." Mackay, 304 U.S. at 345-46. The D.C. Circuit continued:

The Court has repeatedly approved and reaffirmed Mackay Radio. See, e.g., NLRB v. Curtin Matheson Scientific, Inc., 494 U.S. 775, 790, 108 L. Ed. 2d 801, 110 S. Ct. 1542 (1990); Trans World Airlines, Inc. v. Independent Fed'n of Flight Attendants, 489 U.S. 426, 433-34, 103 L. Ed. 2d 456, 109 S. Ct. 1225 (1989); Belknap, Inc. v. Hale, 463 U.S. 491, 504-05 n.8, 77 L. Ed. 2d 798, 103 S. Ct. 3172 (1983); NLRB v. International Van Lines, 409 U.S. 48, 50, 34 L. Ed. 2d 201, 93 S. Ct. 74 (1972); NLRB v. Fleetwood Trailer Co., 389 U.S. 375, 379, 19 L. Ed. 2d 614, 88 S. Ct. 543 (1967); NLRB v. Brown, 380 U.S. 278, 292 \& n.6, 13 L. Ed. 2d 839, 85 S. Ct. 980 (1965); NLRB v. Erie Resistor Corp., 373 U.S. 221, 232, 10 L. Ed. 2d 308, 83 S. Ct. 1139 (1963); NLRB v. Truck Drivers Local Union No. 449, 353 U.S. 87, 96, 1 L. Ed. 2d 676, 77 S. Ct. 643 (1957).

Chamber of Commerce v. Reich, 74 F.3d at 1332 (citations from the original). 
In an interesting development, the Supreme Court distinguished cases where workers were replaced during a so-called "economic strike" - one in which employees were protesting an employer's economic demands - from one in which employees were striking in order to protest the "unfair labor practices" or ULPs, which are specific violations of the NLRA. ${ }^{33}$ These types of strikers

33 The NLRB has the authority to investigate and remedy unfair labor practices, which are defined in Section 8 of the Act. UNFAIR LABOR PRACTICES:

Sec. 8. [29 U.S.C. 158(a) (1994)]. [Unfair labor practices by employer] It shall be an unfair labor practice for an employer:

(1) to interfere with, restrain, or coerce employees in the exercise of the rights guaranteed in section 7 [section 157 of this title];

(2) to dominate or interfere with the formation or administration of any labor organization or contribute financial or other support to it: Provided, that subject to rules and regulations made and published by the Board pursuant to section 6 [section 156 of this title], an employer shall not be prohibited from permitting employees to confer with him during working hours without loss of time or pay;

(3) by discrimination in regard to hire or tenure of employment or any term or condition of employment to encourage or discourage membership in any labor organization: Provided, that nothing in this Act [subchapter], or in any other statute of the United States, shall preclude an employer from making an agreement with a labor organization (not established, maintained, or assisted by any action defined in section 8(a) of this Act [in this subsection] as an unfair labor practice) to require as a condition of employment membership therein on or after the thirtieth day following the beginning of such employment or the effective date of such agreement, whichever is the later, (i) if such labor organization is the representative of the employees as provided in section 9(a) [section 159(a) of this title], in the appropriate collective-bargaining unit covered by such agreement when made, and (ii) unless following an election held as provided in section 9(e) [section 159(e) of this title] within one year preceding the effective date of such agreement, the Board shall have certified that at least a majority of the employees eligible to vote in such election have voted to rescind the authority of such labor organization to make such an agreement: Provided further, that no employer shall justify any discrimination against an employee for non-membership in a labor organization (A) if he has reasonable grounds for believing that such membership was not available to the employee on the same terms and conditions generally 
are termed as "unfair labor practice strikers." 34 In these types of strikes, so-called "unfair labor practice strikers" may be temporarily replaced, but upon the ending of the strike and upon the strikers' "unconditional offer to return to work," the employer must reemploy the strikers regardless of the fact that the employer may have engaged replacement workers or even in a case where the employer has subcontracted out the work formerly performed by the strikers. ${ }^{35}$

applicable to other members, or (B) if he has reasonable grounds for believing that membership was denied or terminated for reasons other than the failure of the employee to tender the periodic dues and the initiation fees uniformly required as a condition of acquiring or retaining membership;

(4) to discharge or otherwise discriminate against an employee because he has filed charges or given testimony under this Act [subchapter];

(5) to refuse to bargain collectively with the representatives of his employees, subject to the provisions of section 9(a) [section 159(a) of this title].

See General Indus. Employees Union, Local 42 v. NLRB, 951 F.2d 1308, 1311 (D.C. Cir. 1991) ("Strikes by employees covered by the NLRA are either economic or unfair labor practice strikes."); Gatliff Bus. Prods., 276 N.L.R.B. 543, 563 (1985) (discussing "two types of strike activity, one of which is called an "economic strike,' and the other of which is termed an "unfair labor practice strike'"); Crossroads Chevrolet, Inc., 233 N.L.R.B. 728, 729 n.4 (1977) ("In labor law, strikes are either economic strikes or unfair labor practice strikes."); Masdon Indus., 212 N.L.R.B. 505, 509 (1974) (referring to "two kinds of strikes, economic and unfair labor practice strikes").

34 See Mastro Plastics Corp. v. NLRB, 350 U.S. 270 (1956).

35 See Cynthia Estlund, The Ossification of America Labor Law, 102 CoLUM. L. REV. 1527, 1538 n.50 (2002) ("'Unfair labor practice strikers,' whose strike is provoked or prolonged by the employer's illegal conduct, are not subject to permanent replacement."). See Midwest Motor Express v. International Bhd. of Teamsters, Local 120, 494 N.W.2d 895, 899 n.4 (Minn. Ct. App. 1993) (observing that "permanent replacements are employees whom the employer need not discharge even if the strikers offer to return to work unconditionally"), rev'd, 512 N.W.2d 881 (Minn. 1994); Gloversville Embossing Corp., 297 N.L.R.B. 182, 182 (1989) (observing that "an employer may permanently replace economic strikers"). See also Keller Mfg. Co., 272 N.L.R.B. 763, 786 (1984) ("Economic strikers are 
A further complication was described by Michael Moberly in a seminal article in the Berkeley Journal of Employment and Labor $\mathrm{Law}^{36}$ where he notes that a strike that begins as an economic strike may be converted to an unfair labor practice strike, ${ }^{37}$ "notwithstanding the continuation of the economic issues that

entitled to reinstatement upon application and if their prestrike positions are filled at the time of application, they retain the right to their former position when it becomes vacant."); Medite of N.M., Inc., 314 N.L.R.B. 1145, 1148 (1994) (indicating that economic strikers "are entitled to ... a substantially equivalent position" that is "left vacant by the departure of permanent replacements"). The Board has held that employers are not obligated "to offer to reinstate replaced economic strikers to vacancies in jobs which they are qualified to perform but which are not substantially equivalent to their former jobs[,]" although economic strikers "are entitled to nondiscriminatory treatment in their application for other jobs." Rose Printing Co., 304 N.L.R.B. 1076, 1078 (1991). By the same token, "an economic striker has no obligation to accept an offer of reinstatement to a position which is not the same [as] or substantially equivalent to his pre-strike position. A refusal to accept such an offer does not extinguish entitlement to full reinstatement to the former or substantially equivalent job...." In addition, “... a striker's acceptance of a position which is not the same as or substantially equivalent to that striker's pre-strike position does not extinguish the statutory right to subsequent reinstatement to a vacant pre-strike position or a substantially equivalent one." $I d$.

${ }^{36}$ Michael Moberly, Striking a Happy Medium: The Conversion of Unfair Labor Practice Strikes to Economic Strikes, 22 BERKELEY J. EMP. \& LAB. L. 131 (2001).

37 See, e.g., Sunol Valley Golf Club, 310 N.L.R.B. 357, 371 (1993) ("It is settled

... that if an employer's unfair labor practice prolongs an economic strike, it converts the strike into an unfair labor practice strike."), enforced sub nom. Ivaldi v. NLRB, 48 F.3d 444 (9th Cir. 1995); Trumbull Memorial Hosp., 288 N.L.R.B. 1429, 1449 (1988) ("Even where a strike has been held not to be an unfair labor practice strike at its inception, an employer's unlawful actions that prolong the strike may convert the strike into an unfair labor practice strike."); Michael H. LeRoy, Institutional Signals and Implicit Bargains in the ULP Strike Doctrine: Empirical Evidence of Law as Equilibrium, 51 HaSTINGS L.J. 171, 219 (1999) ("The Board may ... rule that an economic strike converted to [an unfair labor practice] strike ...."). 
constituted the original basis for the strike, ${ }^{138}$ and even if the economic issues are "more important than the unfair labor practice activity." 39 However, continues Moberly, "an unfair labor practice does not convert an economic strike to an unfair labor practice strike unless a causal connection is established between the unlawful conduct and the prolongation of the strike." ${ }^{40}$ He concludes: "The dispositive question is whether the employees, in deciding to remain on strike, were motivated in part by the unfair labor practices committed by their employer, not whether, without that motivation, the employees might have [continued to strike] for some other reason." 41

${ }^{38}$ Rose Printing Co., 289 N.L.R.B. at 275. See also Superior Nat'l Bank \& Trust Co., 246 N.L.R.B. 721,724 (1979) (indicating that a strike is converted "if the unfair labor practices can be shown to have been a factor in prolonging the strike, even if there were still economic goals"). See generally Burns Int'l Sec. Servs., 324 N.L.R.B. 485, 492 (1997) (observing that "dual motivation does not deprive employees of the status of unfair labor practice strikers"), enforcement denied, 146 F.3d 873 (D.C. Cir. 1998).

39 Burns Int'l Sec. Serv., 324 N.L.R.B. at 492. See also Head Div., AMF, Inc., 228 N.L.R.B. 1406, 1417 (1977) (stating that "a strike's being "primarily" economic does not preclude its having unfair labor practice implications.") (quoting Larand Leisurelies, Inc., 213 N.L.R.B. 197, 197 (1974)), enforced, 593 F.2d 972 (10th Cir. 1979). See generally Domsey Trading Corp., 310 N.L.R.B. 777, 791 (1993) ("Board law is firmly established that a strike is an unfair labor practice strike if the employer's unfair labor practice had anything to do with causing the strike."), enforced, 16 F.3d 517 (2d Cir. 1994).

${ }^{40}$ Robbins Co., 233 N.L.R.B. 549, 549 (1977). See also C-Line Express, 292 N.L.R.B. 638, 638 (1989) ("The Board has long held that an employer's unfair labor practices during an economic strike do not ipso facto convert it into an unfair labor practice strike.").

${ }^{41}$ Moberly, supra note 36, at 137 (citing Northern Wire Corp. v. NLRB, 887 F.2d 1313, 1319-20 (7th Cir. 1989); see also Decker Coal Co., 301 N.L.R.B. 729, 746 (1991) (quoting Northern Wire with approval). In this regard, the Board has indicated that "the usual ... effect of an unfair labor practice committed during a strike is not to prolong [the] strike but to shorten it ...." See Mackay Radio \& Tel. Co., 96 N.L.R.B. 740, 762 (1951). 


\section{THE CONTEXT OF THE LOCKOUT}

In terms of rules of general application which may be applied to the area of sports, courts took a traditional view that there were both permissible and impermissible lockouts. An "offensive lockout" is one initiated by the employer without the employer having any reason to believe that a strike by employees was imminent. An offensive lockout is generally initiated by an employer for the sole purpose of pressuring a union during negotiations. Offensive lockouts were deemed to be ULPs because they inherently coerced employees based on their section 7 rights to bargain collectively. Thus, the Board had long held that "both the lockout and the use of temporary replacements were unfair labor practices" $" 42$ in such circumstances.

A "defensive lockout" is one in which the employer locks out employees in anticipation of an imminent strike. Defensive lockouts were held not to be an ULP and were permissible by an employer in one of three circumstances. The first instance occurred where employees were conducting so-called whipsaw strikes of multiple employers in the same industry. "A 'whipsaw strike' occurs when a union strikes one employer at a time, focusing its resources on one target so that that employer succumbs to the union's demands, allowing the union to then move on to the next." 43 A defensive lockout was also permissible when the union was engaged in what are termed "quickie strikes." A "quickie strike" is an "intermittent work stoppage or a slowdown by which workers attempt to exert

42 DAU-SCHMIDT, ET AL., supra note 20, at 640.

${ }^{43}$ Anthony B. Sanders, Multiemployer Bargaining and Monopoly: LaborManagement Collusion and a Partial Solution, 113 W. VA. L. REV.. 337, 345 (2011) (citing Michael H. LeRoy, Lockouts Involving Replacement Workers: An Empirical Public Policy Analysis and Proposal to Balance Economic Weapons Under the NLRA, 74 WASH. U. L. Q. 981, 999-1000 (1996)). See also NLRB v. Truck Drivers Local Union No. 449 (Buffalo Linen Case), 353 U.S. 87 (1957). 
pressure on the employer without calling an all-out strike." 44

Finally, a defensive lockout was permitted when the union had timed and scheduled a strike in order to coincide with an employer's peak season in a seasonal industry in order to inflict the greatest amount of harm to the employer's business in a defined or limited period of time. $^{45}$ In such cases, the Board held that the temporary replacements of locked out employees was permissible.

These distinctions have been largely eroded as the United States Supreme Court decided that the hiring of temporary replacement workers to continue operations during a lawful lockout does not constitute an unfair labor practice, provided that the employer is not motivated by an antiunion or pro-union purpose. ${ }^{46}$ The purpose of such an action is to simply keep the business in operation. In American Ship Building v. Labor Board, ${ }^{47}$ the United States Supreme Court expressly held that a lockout for the purpose of applying pressure on the union, after an impasse has occurred in negotiations, is not an unfair labor practice under sections 8(a)(1) and (3). However, hiring permanent replacements during a lockout to avoid bargaining obligations has been held to be an ULP and thus unlawful. ${ }^{48}$ The D.C. Circuit noted: "When an employer locks out

\footnotetext{
44 See generally Timothy M. Gill, Public Employee Strikes: Legalization Through the Elimination of Remedies, 72 CAL. L. REV. 629, 641 (citing ROBERT A. GORMAN, BASIC TEXT ON LABOR LAW 318 (1976)).

45 See, e.g., Duluth Bottling Ass'n, 48 N.L.R.B. 1335, 1359-60 (1943) (describing how an employer locked out its employees before they could strike in hopes of preventing a "spoilage of materials"). It would be fair to characterize the lockout of players in cases proximate to the start of the season as a "peak season" lockout - at least from the perspective of the team owners-especially if the players association had indicated its clear intention to strike once an impasses in negotiations was reached.

46 Local 825, Intern. Union of Operating Eng'rs v. NLRB, 829 F.2d 458 (3d Cir. 1987).

47380 U.S. 300 (1965).

48 Pankratz Forest Industries, 269 N.L.R.B. 33, aff'd, 762 F.2d 1018 (9th Cir. 1985).
} 
its employees for the purpose of evading its duty to negotiate with the employees' bargaining representative," or to "coerce the [u]nion to accept the [employer's] unilaterally implemented final offer," the employer violates the Act. ${ }^{49}$

Interestingly, the Court expressly stated no view as to the consequences which would follow if the employer replaced the employees with permanent replacements or temporary help, ${ }^{50}$ although the Board still held to its view that the use of replacement workers was illegal. What developed in a series of enforcement actions was a conflict among the circuit courts of appeals as to the question of whether an employer engaged in a lockout may hire temporary replacements for the sole purpose of bringing economic pressure in support of its legitimate bargaining position. The Seventh Circuit has held that a bargaining lockout accompanied by continued operation with temporary replacement labor is per se an interference with protected employee rights and an unfair labor practice. ${ }^{51}$ However, the Third Circuit has adopted the contrary view. ${ }^{52}$ The District of Columbia Circuit, like the Third Circuit, has ruled that an employer that has lawfully locked out its permanent employees does not act unlawfully by operating with temporary replacement workers in order to bring economic pressure on the union in support of its bargaining position, since such an employer action is not inherently destructive of employee rights, and any

49 Teamsters Local Union No. 639 v. NLRB, 924 F.2d 1078, 1085 (D.C. Cir. 1991). See also Anderson Enters., 329 N.L.R.B. 760, 766 (1999) (holding a lockout unlawful when "utilized to enable [the employer] to implement its own bargaining position without ... genuine impasse"), enf'd, 2 Fed. App'x 1 (D.C. Cir. 2001).

50 American Ship Building, 380 U.S. at 308 n.8.

51 Inland Trucking Co. v. NLRB, 440 F.2d 562 (7th Cir. 1971).

52 Local 825, Intern. Union of Operating Engineers v. NLRB, 829 F.2d 458 (3d Cir. 1987). 
effect on the parties' relative bargaining power, so long as it does not substantially impair the employees' ability to organize and to engage in concerted activity, is not regulated by the NLRA. ${ }^{53}$

Refusing to adopt the per se rule formulated in Inland Trucking, the Eighth Circuit in Inter-Collegiate Press, Graphic Arts Division v. NLRB ${ }^{54}$ found no violation of section (a)(1) where the company hired temporary employees during a lockout. The court reasoned that while there is coercion present when an employer locks out his employees, and the coercion may be magnified when the employer continues to operate with temporary employees, the coercion is to force acceptance of the employer's bargaining position, not to foreclose the employees' opportunity to exercise protected rights. ${ }^{55}$ Citing American Ship Building, the court stated:

Proper analysis of the problem demands that the simple intention to support the employer's bargaining position as to compensation and the like be distinguished from a hostility to the process of collective bargaining. ... 56

However, in Harter Equipment, Inc., ${ }^{57}$ a divided NLRB had changed its mind and upheld the legality of hiring temporary replacements during an offensive lockout. At that point, the courts of appeals accepted this new view of the Board concerning the

\footnotetext{
53 International Bhd. of Boilermakers, Iron Shipbuilders, Blacksmiths, Forgers and Helpers, AFL-CIO, Local 88 v. NLRB, 858 F.2d 756 (D.C. Cir. 1988) (referring to 29 U.S.C.A. $§ 158(a)(1)$ and (3) and upholding the use of temporary replacements during a lockout).

54 Inter-Collegiate Press, Graphic Arts Division v. NLRB, 486 F.2d 837 (8th Cir. 1973), cert. denied, 416 U.S. 938 (1974).
}

${ }^{55}$ Id. at 846.

${ }^{56} I d$.

57280 N.L.R.B. 597 (1986). 
legality of using temporary replacement workers during an offensive lockout in two cases: Local 825, Int'l Union of Operating Engineers v. $N L R B^{58}(1987)$ and International Brotherhood of Boilermakers $v$. $N L R B^{59}$ (1988). It thus appeared that any distinction between offensive and defensive lockouts had largely disappeared. Employers were able to hire temporary replacements regardless of the nature of the lockout.

As a practical matter, the NLRB has continued to permit the use of temporary workers during a lawful lockout, in instances where the employer had previously entered into a series of three-year agreements with the union, was not motivated by specific anti-union animus, eventually reached an agreement containing higher wage rates, and had reasonably demanded a three-year agreement to enable it to continue smooth operations after the union had refused to accede to a no-strike clause, ${ }^{60}$ or where the employer had intended to perform clerical work with non-union employees at the outset and hired temporary replacements, whom it terminated when an agreement was reached, only after an increase in clerical workload, and there was no evidence of anti-union animus. ${ }^{61}$

The use of replacement workers may also be lawful where the replacements are expressly hired only for the duration of the labor dispute, a definite date is given for their termination, the employees have the option of returning to work on the employer's terms, which are better than those in the old contract, and the employer has already agreed to continue a union security clause that is in effect; ${ }^{62}$ or where the replacements are expressly used for the

58829 F.2d 458 ( $3^{\text {rd }}$ Cir. 1987).

59858 F.2d 756 (D.C. Cir. 1988).

${ }^{60}$ Georgia-Pacific Corp., 281 N.L.R.B. 1 (1986).

${ }^{61}$ Marquette Co., 285 N.L.R.B. 774 (1987).

${ }^{62}$ Inter-Collegiate Press, Graphic Arts Div. v. N.L.R.B., 486 F.2d 837 (8th Cir. 1973). 
duration of the labor dispute only, and the lockout does not have a great tendency to discourage union membership. ${ }^{63}$

After a lockout has ended, an employer's refusal to use regular union employees and its continued operation with temporary replacements may be deemed to constitute unlawful discrimination and thus an ULP. ${ }^{64}$

${ }^{63}$ Ottawa Silica Co., 197 N.L.R.B. 449 (1972).

${ }^{64}$ NLRB v. Brown, 380 U.S. 278 (1965). There is also a management tactic, termed as a "partial lockout," during which it will seek to operate its business during the lockout. In some cases, management will use supervisory personnel, independent contractors, or some temporary employees in order to "stay open." See Midwest Generation, 343 N.L.R.B. 69 (2004) (the NLRB decision); Local 15, I.B.E.W. v. NLRB 429 F.3d 651 (2005) $\left(7^{\text {th }}\right.$ Cir. 2005). For an extensive discussion of the two viewpoints presented in Midwest Generation, see C. Quincy Ewell, The Key to Unlocking the Partial Lockout: A Discussion of the NLRB's Decisions in Midwest Generation and Bunting Bearings, 112 PENN. ST. L. REV. 907 (2008).

In the appellate case, the court reached the following conclusions: 1. Operational needs did not justify the partial lockout; 2 . The partial lockout was not justified as a lawful means of economically pressuring holdouts; and, 3. Midwest [the employer] displayed anti-union animus.

The court concluded:

A partial lockout is a significant measure that requires a justification beyond economic effectiveness. The fact that employees could avoid partial lockouts by agreeing to employer demands would in effect validate all partial lockouts. Undoubtedly, this would render ineffective the requirement of a legitimate and substantial business justification for discriminatory employer action and would be in derogation of nearly four decades of employee protection.

Local 15, I.B.E.W., 429 F.3d at 661 (citing NLRB v. Great Dane Trailers, Inc., 388 U.S. 26 (1967). See also 29 U.S.C. §§ 157, 158(a)(1)). Accordingly, the Seventh Circuit reversed the findings of the Board in Midwest Generation and remanded the case to the Board with instructions to find that the partial lockout was an unfair labor practice. 
The use of permanent replacements during a lockout is a different matter. While, as noted, courts have permitted the use of temporary replacements during either a defensive or an offensive lockout, the question may evince a different response, as indicated by the D.C. Circuit in International Brotherhood of Boilermakers $v$. N.L.R.B. ${ }^{65}$ when it noted that permanently replacing locked out workers "might too easily become a device for union busting." 66 In

As to the issue of the role of an appellate court in reviewing the decisions of the NLRB, the Seventh Circuit noted: "Board Rulings are 'entitled to considerable deference so long as [they are] rational and consistent with the [National Labor Relations] Act."' Local 15, I.B.E.W., 429 F.3d 651 (2005) $\left(7^{\text {th }}\right.$ Cir. 2005). See also NLRB v. Curtin Matheson Scientific, Inc., 494 U.S. 775, 787, (1990); NLRB v. United Food, Commercial Workers Union, Local 23, 484 U.S. 112, 123 (1987). The Seventh Circuit added in Local 15, I.B.E.W.: "This Court, however, is not 'obliged to stand aside and rubberstamp [its] affirmance of administrative decisions that [it] deems inconsistent with a statutory mandate or that frustrate the congressional policy underlying a statute." See also NLRB v. Brown, 380 U.S. 278, 291 (1965)). These cases represent the conundrum of an NLRB and a Court of Appeals that may have a very different view of the rights and prerogatives of labor and management in a labor dispute.

65858 F.2d 756 (D.C. Cir. 1988).

${ }^{66}$ Id. at 769 (quoting Bernard D. Meltzer, The Lockout Cases, 1965 Sup. Ct. Rev. 87, 104). In Boilermakers, the circuit court noted: "We do not mean to suggest that a lockout followed by permanent replacements would necessarily be a lawful tactic under the Labor Act. We express no opinion on that question, as it is not before us today, except to note that it raises somewhat different concerns than those suggested by a strike with permanent replacements." Id. (emphasis in original). See also Elliott River Tours, 246 N.L.R.B. 935 (1979 (allowing temporary subcontracting during a lockout only upon the showing of "business necessity”); Land Air Delivery v. NLRB, 862 F.2d 354 (D.C. Cir. 1988) (upholding the Board's determination that an employer had committed an ULP by permanently contracting out a bargaining unit during a strike without notifying and bargaining with a unit); International Paper Co. v. NLRB, 115 F.3d 1045 (D.C. Cir. 1997) (concluding that economic reasons as put forth by International Paper through permanent subcontracting constituted legitimate and substantial business justifications and which had a comparatively slight effect on employee rights under the Act). 
International Paper v. NLRB, referencing Boilermakers, the D.C. Circuit Court continued:

The point we made in Boilermakers suggests that an employer may have greater difficulty precipitating a strike if the labor market can provide permanent instead of temporary replacements. Nonetheless in both instances the identical concern exists that the employer will attempt to precipitate a strike while purporting to be engaged in good faith bargaining. Thus both cases raise the problem of employer brinkmanship that may 'poison the atmosphere' of collective bargaining. ${ }^{67}$

\section{REPLACEMENT WORKERS/PLAYERS IN THE CONTEXT OF PROFESSIONAL SPORTS}

Professors Dau-Schmidt, Malin, Corrada, Cameron, and Fisk note: "From 1938 until 1980, it was rare for companies to permanently replace striking workers."68 Among the reasons for this conclusion include: hiring striking replacements makes strikers extremely unhappy which might tend to "galvanize support for the strike" and which can prolong it rather than shorten it; ${ }^{69}$ replacement workers made it harder to settle a strike, as the underlying dispute would now have another contentious issue relating to the "fate of the replacement workers and the returning strikers"; 70 and, relations between any strikers and any replacement

67 Int'l Paper, 115 F.3d 1045, 1051(D.C. Cir. 1997) (quoting Meltzer, The Lockout Cases, 1965 Sup. Ct. Rev. at 105).

68 KenNeth G. DAU-SCHMIDT, Et Al, supra note 20, at 614 (2009).

${ }^{69} I d$.

${ }^{70} \mathrm{Id}$. 
workers retained after the strike was concluded would "likely to be hostile for months and years after the end of the strike."71

These general observations hold true in the area of professional sports. As Professor Hayden noted: "During the Major League Baseball strike in 1994, some of the owners embarrassed themselves by toying with the idea of continuing the season using replacement players." ${ }^{, 72}$ The situation was also complicated by the fact that the NLRB had concluded that the strike had undergone a legal metamorphosis and had been transformed into an unfair labor practice strike before the date on which any replacement players were hired. ${ }^{73}$ It should also be noted that while replacement players were used for three games during the 1987 professional football strike, "the effort was not very successful, and probably only possible because football players, with the exception of star players in the skill positions, are relatively anonymous in comparison to their counterparts in baseball, basketball, and hockey.",74 Professor Hayden concludes (perhaps the obvious) that "Professional athletes operate in what is essentially a closed labor market, which gives

71 Id. In addition, and in relation to the NFL strike, several of the players who crossed the picket line were major "super stars" such as Joe Montana, Tony Dorsett, Steve Largent, Lawrence Taylor, and Doug Flutie. All of these playerswith the exception of Doug Flutie - are members of the Football Hall of Fame! It is also interesting to see a managerial perspective on the use of replacement players in professional baseball. See, e.g., Tim Kukjian, Who's On First, Joe? The Cardinals' Joe Torre, Like Other Managers, Finds Replacement Players to Be Excess Baggage," SPORTS IlluSTRATED, Mar. 6, 1995 (cited in Ed Edmonds, At the Brink of Free Agency: Creating the Foundation for the Messersmith-McNally Decision 1968-1975, 34 S. ILL. U.L.J. 565, 574 (2010)).

72 Hayden, supra note 2, at 462 (citing Steven Greenhouse, Power Bargaining: Walking the Picket Line in Gucci Loafers, N.Y. TIMES, Nov. 22, 1998, at 4).

73 DAU-SCHMIDT, ET AL, supra note 19, at 617 (citing WiLliam B. Gould, LABORED RELATIONS (2002)).

74 Id. (citing Murray Chass, As Trade Unions Struggle, Their Sports Cousins Thrive, N.Y. TIMES, Sept. 5, 1994, at 1). 
them a tremendous advantage over their counterparts in other occupations.",75

Further, in the arena of sports, the choice to hire replacement players involves a traditional analysis involving both economics ${ }^{76}$ and the integrity and continuity of the sport; in essence, to utilize replacement players or to shut down operations. But the decision cannot be made unilaterally, as with a single manufacturing operation. ${ }^{77}$ Since a team is a member of a league, the league will

${ }^{75} I d$.

76 For example, as Jake Fisher reports: "According to the Nielsen ratings, in 2008, five of the top 10 single-event television broadcasts were NFL-related. Because of this, television networks pay a premium for NFL contests." See Jake Fisher, Television and the Potential NFL Lockout, Harv. Sports Analysis Collective, Nov. 18, 2009, http://harvardsportsanalysis.wordpress.com.ezproxy.shu.edu/2009/11/18/ television-and-the-potential-nfl-lockout.

77 It seemed however, that two-thirds of the league teams found replacement players, while the striking players, on the other hand, had limited financial reserves and the union had no "strike fund" prepared. See generally Paul D. Staudohar, The Football Strike of 1987: The Question of Free Agency, 111 MONTHLY LAB. REV. 26, 29 (1988).

Concerning the NFL strike action in 1987, Adam Marks reported:

Soon after the failed strike of 1982, Gene Upshaw replaced Ed Garvey as the executive director of the NFLPA. Upshaw's first renegotiation of the collective bargaining agreement took place during the summer of 1987, and, like the previous renegotiations, resulted in a strike. Similar to 1982, the league was in control of the strike from the beginning, but unlike during previous strikes, the teams had signed replacement players to ensure that the regular season games would not be affected by the striking players union. [The replacement players were mostly comprised of players already cut during the 1987 preseason.] Although Upshaw was able to garner some support among organized laborers in NFL cities, the NFLPA had not prepared to support its players financially during a prolonged strike. Over the course of the strike, the players lost approximately $\$ 80$ million and, as in 1982 , veteran players crossed the picket line before the end of the strike, destroying any strength the union had in negotiations. Gene Upshaw's first negotiation as head of 
need to balance the short-term financial/revenue impact "resulting from a lack of games with the potential long-term effects of producing an inferior product for the fans and passing it off as the same quality of entertainment and competition." Mr. Tyras asserts, "Hiring replacement players also raises important issues, such as the potential presence of local labor laws prohibiting the use of replacement workers when the normal workforce is being locked out, and the long-term effects on the game's fan base from passing off such games as "major league.",79

the players union, and first opportunity to return the union to prominence, was a disaster.

Adam S. Marks, Personnel Foul on the National Football League Players Association: How Union Executive Director Gene Upshaw Failed the Union's Members By Not Fighting the Enactment of the Personal Conduct Policy, 40 CONN. L. REV. 1581, 1588 nn.43-281 (2008).

${ }^{78}$ Jonathan C. Tyras, Players Versus Owners: Collective Bargaining and Antitrust After Brown v. Pro Football, Inc, 1 U. PA. J. LAB. \& EMP. L. 297, 334(1998). In addition, there was a real concern that fans might react quite negatively in the long-run if replacement players took the field. See, e.g., Poll: Strike Has Eroded Interest: Sharp Decline in Attendance Is Projected if Replacements Are Used, SACRAMENTO BEE, Feb. 28, 1995, at Sports D8.

79 In March 1995, the Maryland General Assembly passed legislation precluding teams from playing baseball in Oriole Park at Camden Yards in Baltimore if more than twenty-five percent of ther player roster had not been on major league rosters in 1994. See Md. Code ANN., FIN. InST. § 13-723(b) (1992 \& Supp. 1995). See Peter F. Giamporcaro, No Runs, No Hits, Two Errors: How Maryland Erred in Prohibiting Replacement Players from Camden Yards During the 1994-95 Major League Baseball Strike, 17 LOY. L.A. ENT. L.J. 123, 123 (1996). 
The Journal of SPORT, 2012, 1, 34-54

(C) Kent State University

\title{
Establishing a Strategic View of Sport Events: Marketing a Multiphase Sport Experience
}

\author{
Lana L. Huberty \\ University of Minnesota \\ Stephen D. Ross \\ University of Minnesota
}

\begin{abstract}
The multiphase leisure experience looks at the experience as a five phase process that includes anticipation, travel to, onsite behavior, travel from, and recollection. This continuum depicts a dynamic experience, one that evolves and matures across the five phases. The purpose of this study is to take this model and apply it to sport events. Understanding sport events as a multiphase experience will require a new way of thinking and new research endeavors. This paper serves the purpose of both increasing the awareness of multiphase sport experiences and providing direction for future research. Sport events will continue to grow in number and the multiphase sport experience research will allow sport organizations an opportunity to provide a better, more satisfying service experience for the sport consumer. It will also allow marketers to evolve their event brands through additional ancillary and secondary service elements. Overall, recognizing an event as a multiphase experience will create a competitive advantage for sport event marketers wishing to develop and/or maintain strong brand equity. This will enable sport managers to strategically outperform competitors and differentiate from the others to stay competitive.
\end{abstract}


Sport event managers and organizations are faced with an increasingly saturated market place. This has a significant impact on the marketing of sporting events in several ways. Organizations are finding themselves with limited resources and managers needing to offer expanding opportunities for consumers. These fast changing times show the limitations of traditional views of strategic management and instead demonstrate a must for globalization. Now, more than ever before, event marketers will be required to stay relevant in the marketplace to outperform competitors. Consumer satisfaction with a sports event experience is critical to developing team support, attendance, and revenue for organizations in the multibillion dollar sports industry (Koo, 2009).

With these challenges, strategic marketing perspectives become a necessity for sport event managers. The essence of strategic event management is to determine why some events outperform others, and sustainable competitive advantages are possible through performing different activities from rivals or through performing similar activities in diverse ways. Sport managers need to determine how an event should operate so that it can create advantages that are sustainable over a long period of time, thus putting an emphasis on positioning through differentiation of a sport experience.

Event marketers are faced with the question of how to compete in order to create competitive advantages in the marketplace and how can these competitive advantages be created that are not only unique and valuable, but also difficult for competitors to copy. If all marketers do is duplicate what rivals are doing, eventually mutual destructive competition will occur, offering no long-term advantage.

As such, event managers need to look beyond the management and marketing of the onsite event experience for differentiation. Historically focus has been on the core, onsite product and much research has emphasized the main event. However, sport spectatorship is a transient experience that evolves as the event takes place and stronger emphasis is needed on the other parts of the event process, as consuming an event is a multiphase experience. Marketers have come to realize that understanding the 
consumer experience is critical for developing marketing strategies. Consumption experiences occur before, during, and after the event: when consumers search for products, when they shop for the service, when they are in the process of consuming them, and after the event has ended (Holbrook et. al, 1984). Therefore, the sport experience can be considered to be a multi-contact, multiphase, transient, shifting, continuum of time experience. The total experience offers the consumer the opportunity for satisfaction and dissatisfaction in each phase of the experience (Borrie \& Roggenbuck, 2001).

Past research has examined a number of leisure related experiences such as wilderness experiences (Borrie \& Roggenbuck, 2001), outdoor recreation (Hammit, 1980) and daily routine (Burke \& Franzoi, 1988). Here it was recognized that leisure is not simply a state of mind; but instead states of mind. These states might, for example, include several types of positive emotions, personal meanings associated with the challenges of leisure environments, and cognitions related to such things as way-finding during leisure travel. Life experiences can be measured by emotion, mood, attention states, feelings, connections with others, and attitudes. Second, the multiple states are dynamic, evolving, and dependent in part on context (Borrie \& Roggenbuck, 2001). Taking this paradigm a step further, understanding an event as a multiphase brand experience will require a new way of conceptualizing and conducting the research. Little research in sport marketing has addressed sport services from a multiphase perspective.

The multiphase recreation and leisure experience research entailed a multiphasic approach (Hammit, 1980; Burke \& Franzoi, 1988; Borrie \& Roggenbuck, 2001). Expanded examination of a sport event experience could be conducted utilizing a similar model, one altered in designed to include the five phases of anticipation, travel to, onsite behavior, travel from, and recollection. Each of the five phases would be explored within a sporting event context and studied from a sport marketing perspective. These phases are shown in Figure 1. 
Figure 1: Five Phases of the Multiphase Experience

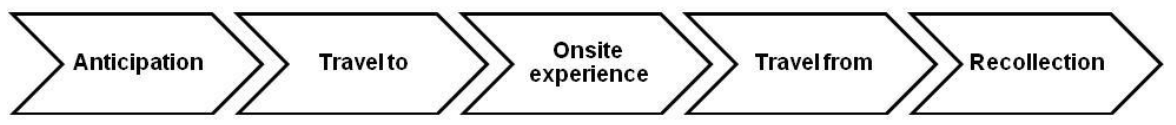

\section{Phase One: Anticipation}

The first phase, anticipation, deals with looking to the future event when thinking about and planning such things such as transportation, reservations, and lodging (Snepenger, 1987). During this stage consumers often visualize themselves actually involved in the activity. The anticipation phase is similar to impression management, where mental imagery becomes a crucial component of anticipation (Burns et. al, 1993). These images influence spending patterns, anxiety, and attitudinal states prior to actual event experience. Heightened anxiety and anticipation states also create images and perceptions influencing attitudes and buying behavior. Travel planning and decision making involves consumer's environmental preferences along with cognitive images. Consumers tend to use images that go beyond the promotional brochures, and an individual only needs a few details to form an impression. It is important to acknowledge that images from consumers will vary depending on age, home residence, occupation, income, and other characteristics (Fridgen, 1984). Visualization can continue not only throughout the anticipation phase, but into the next phase (travel to) and, depending on the meaning of the activity to the participants, emotions such as anxiety and exhilaration may change as one nears the actual event site (Hultsman, 1998).

MacInnis and Price (1987) defined imagery as a process by which sensory information is represented in working memory. 
Imagery and information processing falls on an elaboration continuum that ranges from processes limited to the simple evocation of a cognitive concept to processes involving multiple concepts and constructs such as problem solving, creative thinking, and daydreaming. Since imagery relies on stored knowledge, the vividness of the image depends on the level of knowledge development. Imagery may be multisensory involving images that incorporate smell, taste, sight and tactile sensations; or the image may involve a single sensory dimension such as sight. This concept affects sports marketers in several ways and sport researchers have acknowledged the importance of brand association networks (Ross, 2006). In similar research on imagery, Lutz and Lutz (1977) found pictures or imagery-eliciting stimuli in advertisements had a positive effect on memory for product-relevant information. A more recent study identified self-imagery as a benefit variable linking product attributes and consumer values which directly abetted consumer demand satisfaction (Lin \& Huang, 2009).

Other factors of the anticipation phase include consumers beginning to make predictions and odds of winning being calculated. For events involving competitions, anticipation is influenced by teams or athletes chance of winning or placing high. It is during the anticipation phase that performance ideas start to develop, and these expectations are largely based on previous performance and records. Other factors involve social interaction with other consumers who may be involved in the experience. The interaction affects the social roles one consumer plays with another, as do the attributes connected with each role (Borrie \& Roggenbuck, 2001).

The dissonance theory (Hultsman, 1998) plays a role in the anticipation phase as consumer motives, expectations, and preferences all change across time. Therefore, pre-activity measures may not be at all consistent with post-activity measures. The basis for the dissonance theory describes the human ability to maintain cognitive consistency even when faced with unmet expectations. Thus, for a sport event, one could expect a significant correlation between the chances fans thought their team would win and their level of satisfaction of the overall performance. However, one might also assume that high levels of satisfaction could be obtained without 
actually winning since unanticipated setting or programmatic circumstances might cause one to adjust expectations and consider other ways to have a satisfying experience.

Information search is often parallel to or integrated with the activity of consumer buying, or during the planning done in the anticipation phase. The information processing model of consumer behaviors has been extensively applied to understanding the tie between seeking, collecting, and applying information to make more rational product choices. Individuals vary greatly on the amount and sources of information they need to make a purchase decision. Product contexts are important for researchers to consider as individuals have many different purchase and informational styles (Vogt \& Stewart, 1998). Often consumers utilize a variety of internal and external sources of information in making their purchasing decisions and knowledge of this information search process can help sport marketers better meet consumer needs.

\section{Phase Two: Travel To}

Phase two of the multiphase experience is travel to, which involves the carryover of anticipation and excitement for the event created in phase one. Travel to pertains to the process of getting to the event itself and is very important for event branding and loyalty initiatives. Issues to keep in mind in phase two include sport as a social experience and that traveling together is common, and can be a crucial part of the experience (Fridgen, 1984). Also, building social identity and a brand community may occur during this phase. Research has examined how people influence each others' feelings during their interactions (Gump \& Kulik, 1997; Howard \& Gengler, 2001). Social and physical constraints converge upon the individual in the car, train, or bus and privacy, territoriality, and personal space are all concepts that in often unconscious ways are sensitive issues for the consumer (Fairley, 2009).

Event location is another critical aspect of this phase due to access points. The travel to phase may take the consumer through a variety of environments, each of which is briefly viewed from the transportation vehicle. The environment surrounding the event is one medium used by a community to express itself, informing visitors 
about its attractions and hospitality. It has been found that the true spirit of the community is carried by the people, and by buildings, designs and plans which are consciously carried out by the community (Fridgen, 1984).

A recent sport event study done by Robbins , (2007) provided a conceptual framework for examining the transport implications of holding events. At the center of the framework lies the impact of travel to events at a destination-specific and wider area level. Surrounding this are four elements of events and destinations that significantly influence the likely transport impacts on and benefits to the destination area. These four elements include event typology, event destination/organizational issues, event/tourism practices, and event destination geography. Both positive and negative transport impacted event satisfaction with the most desirable event locations for planners being permanent facilities like stadia (Robbins et al., 2007).

Statistical analysis of European tourism show the car dominated domestic tourism travel, accounting for around $71 \%$ of all trips to and from holiday destinations. The high volume of cars create significant negative environmental impacts to host destinations, especially in rural areas where road infrastructure often is not designed to cope with high traffic flows (Robbins et al., 2007). Other examples of research areas in this phase may include public transportation, traffic patterns, crowd management, weather and parking implications.

Specific research in the travel to phase has been conducted with a focus on fans traveling by bus (Fairly, 2009). The bus trip was found to have a symbolic importance to the group under investigation to the point where the bus was a central component of the group's identity. Travel time on the bus was particularly conducive for both social interaction and camaraderie, which allowed individuals to consolidate and strengthen the group identity. Actual travel can have a key role in setting the social climate for the sport experience. The travel element has been seen as a necessary evil to enable individuals to achieve what has been seen as an end goal of watching an event. This viewpoint has led to the act of travel being viewed simply as incidental to the experience (Daniels et al., 
2005). In reality however, the time spent on actual travel can sometimes outweigh the time spent at the destination itself.

\section{Phase Three: Onsite Experience}

The third phase in the multiphase experience is onsite experience. Onsite experience concerns the spectators' behavior and interactions at the event itself and onsite experience is where most of the past and current research has been concentrated. Behaviorsetting analyses are the focus of typical sport marketing and management research, measuring the satisfaction and results of service interaction (Fridgen, 1984). Environmental psychology plays an important role in this phase as does the consumers' emotional involvement. Borrie and Roggenbuck (2001) performed a research project focused on participants of an Outward Bound trip in the wilderness. In this study, the participants most often were concerned with the social acceptance by the group, followed by a focus on the tasks, the environment, and finally on themselves. During the actual recreational activity participants described their feelings, likes, and dislikes. They frequently mentioned positive emotions and benefits, but at the same time described feelings of exhaustion, nervousness, disappointment, frustration, and guilt.

This actual activity phase may focus on a singular event or a series of related events in the sporting context. The longer the event lasts, the more likely the participants are to experience changes in moods and attitudes toward or related to participation (Hultsman, 1998). Koo (2009) conducted research on three aspects affecting fan satisfaction while in attendance of a sports event (technical quality, functional quality, and environmental quality). All three of these aspects were found to have statistical significance in positively affecting the perceived service quality. In other words, the perceived service quality was determined by a fan's evaluation of a total of service dimensions, of which some are technical, some are functional and some are environmental in nature. Furthermore, the results provided support for the positive casual relationship between perceived service quality and spectator satisfaction.

As with the anticipation phase, imagery can also play a role during the actual consumption experience. Many products are 
purchases explicitly for the fantasy imagery they generate (Holbrook et al., 1984). Playful consumption, which includes leisure activities, sports, games, etc., is a domain where imagery appears to play a particularly important value-enhancing role (MacInnis \& Price, 1987). Thus, imagery in the consumption phase has the potential for increasing product satisfaction. The concept of authenticity also suggests that experience satisfaction is related to the perception of authentic attractions. Satisfaction is diminished if the consumer feels that the settings are faked or staged. This could be true of a sporting event incident or game outcome. The results of the interaction between the consumer, the host, and the facility contribute to the total onsite experience (Fridgen, 1984).

Personnel dimensions is an influential experience factor (Theodorakis \& Alexandris, 2008). This refers to the service provided by employees on game day including the feelings of "fairness" created by the credibility of the team administration and the employees. Service quality was a key issue for organizational success, relating directly to increased consumer loyalty and higher profits. A customer with positive service quality perceptions was likely to report high levels of satisfaction and subsequently develop attitudinal and behavioral loyalty with the organization and its services (Theodorakis \& Alexandris, 2008).

The tangible aspect of the service is an important element of marketing the event. In this respect, the stadium is the place where the sport product or game is produced and simultaneously consumed by the fans (Robbins et al., 2007). It is likely that aspects of the onsite experience phase are related to the team's on-court or on-field performance, as this would have a strong effect on a sport fans' overall experience (Theodorakis et al., 2008). Since sport marketers lack influence over the outcome of the game, they should focus on aspects such as facility design and ambience, cleanliness, personnel behaviors, and secondary services like restaurants and cafes.

\section{Phase Four: Travel From}

The next phase, travel from, deals with the return travel aspect of the experience or the travel home phase. This is probably the least examined phase of the multiphase sport experience, and as 
such, it is the least understood. Travel from incorporates many of the same issues associated with the travel to phase such as crowding, transportation and traffic patterns. Travel from could possibly be differentiated from travel to with the fatigue factor setting in or by the opportunity for side trips (Hultsman, 1998). When the sport event has ended, the participants either head home or on to another activity, and at this time, initial reflection regarding one's experience takes place. Participants may experience tiredness or rejuvenation, relaxation or anxiety, jubilation or depression, etc. Discussions that take place on the way home are likely to be very different than those while traveling to (Borrie \& Roggenbuck, 2001.)

Research has found the travel from phase involves a change in consumer moods. The increased mood level occurring during the on-sight sports event did decrease as the consumer moved into and through the travel from phase (Nawijn, 2010.) Often respondent's thoughts were of going home and how fast the time had gone by. Sport marketers must recognize the role these changes in mood play in this phase of the event experience.

\section{Phase Five: Recollection}

Recollection is the final phase of the multiphase sport experience, and includes the recall, reflection, and memory of the other four phases of the event experience (Walker et al., 1998). Commonly studied fan characteristic variables influencing this phase are fan identity, fan motivation, and brand associations (Theodorakis $\&$ Alexandris, 2008). The recollection phase involves consumers consolidating impressions and perceptions into memories, emotions and evaluations into their own stories. Expectations that initiated the event plan are now merged with actual experiences and shortfalls and achievements are reflected upon and integrated into new images (Fridgen, 1984). Influencing what people remember is perhaps the greatest tool that a marketer can use to build brand equity. Theodorakis and Alexandris (2008) discovered that a previous positive experience is an extremely valid determinant of future purchasing decisions. In one study comparing gender recollections, females recalled more positive social aspects of the activity than the male participants. In addition, it was found that negative experiences 
fade, while the more positive experiences were recalled with more accuracy.

Obviously, differential memory effects are at play during this phase of the multiphase experience (Fridgen, 1984) and stories told about the experience are not limited to those experiences of just the present. Consumers with a history at the event may remember the best stories from the past and enjoy reliving and retelling them as part of the current experience. The exchanging of stories is often a part of the final phase of the experience (Patterson et al., 1998). Depending upon the meaning associated with the multiphase sport experience, this phase may continue until the experience occurs again. Therefore, the anticipation phase could actually overlap the recollection phase from the previous experience (Hultsman, 1998).

During the first four phases of the sport experience, the consumer is likely to interact with multiple service providers. Satisfaction with these personal interactions will be influential to the experiences throughout the anticipation, travel to, onsite, and travel from phases (Neal et al., 1999). Satisfaction and recollection are also dependent on the imagery created throughout the multiphase sport experience (MacInnis \& Price, 1987). Upon completion of these four phases, attitudes and perceptions about the event, community, and environment may have transformed. The final phase allows these new perceptions to shape consumers' future behaviors and event experience decisions. One possible broadening effect of the experience is a continued exploration of event-related products and activities after the return home. The broadening effect offers a great tool for sport marketers to use to build brand awareness and equity, such as team merchandise and future ticket sales. Another broadening effect example could be purchasing a collector book of the team, players and sport facility associated with the event.

Positive recollections influence making decisions about future consumption behaviors. The tendency to save mementos, ticket stubs, and photos indicates consumers' desires to relive the experiences. Imagery plays an important role in this process suggesting that an experience can last well beyond its conceived duration. Sport marketers need to realize and learn to capitalize on 
the influential role that elaborated imagery plays in consumer repurchase behaviors (MacInnis \& Price, 1987; Lin \& Huang, 2009).

\section{Suggested Research Methodologies}

Recognizing a sport event as a multiphase brand experience brings about a significant need to conduct research in all phases of the event consumption experience. This research may include sport events taking place at their physical locations as well as the social behaviors unfolding during the experience. This combination of research could be difficult given the limitations of conducting research and logistical constraints. The variable levels of emotion support the idea that not only does each phase fluctuate in satisfaction, but these levels of satisfaction vary within each phase. Quite surprising, research has paid little attention to consumers' moods, with the focus most often on customer satisfaction (Nawijn, 2010.) Typically, research in these areas may include retrospective studies, or pre and post experimental designs. Ideally, researchers would sample and collect data during each phase of the actual experience. Two common sampling methods that can be utilized to achieve this purpose include Experimental Sampling Method (ESM) and Phenomenon Sampling Method (PSM). However, Experimental Sampling Method is the recommended method proposed here, and further discussion is provided hereafter.

\section{Survey Method}

The Experimental Sampling Method was developed by Csikszentmihalyi and associates, and involves detailed monitoring of respondents' daily behavior. This monitoring was originally done through the use of electronic pagers which were activated by the researcher on a random basis. When the pager sounded, respondents were required to fill out a short questionnaire that focuses on 'where you are', 'what you are doing', 'who you are with', and 'your mood at the time.' Experimental Sampling Method has the advantage of providing real-time data on environmental context, feelings and activities (Larson \& Csikszentmihalyi, 1983). Keeping with the concept of a sport experience being a multiphase experience, the true measure of an individual's experience can be derived only from a 
moment-to-moment sampling of the behaviors, thoughts and feelings during the experience.

Benefits of using ESM are that participants do not suffer from the deficiencies of other methods such as memory decay, participants do not feel pressured to give socially desirable responses, and ESM prevents overgeneralization. Close association in time between actual experience and data collection is also a valuable tool for validity checks. Previous ESM challenges of the cost of the procedures and the logistics have been addressed with recent advancements in technology. Now there exists a more realistic possibility for conducting this research using ESM as most respondents are mobile and self-wired with access to texting and direct online surveys. Other communication examples could include the use of tablet computers or cell phones with onsite surveys. These options would offer instantaneous results and real time data collection. The ESM provides contextually specific data at physical locations chosen by the researcher and also some initial meanings that the individuals attach to the experience. The combination therefore is synergistic, enabling a much more comprehensive understanding of the experience than other methods provide.

Previous researchers conducted utilizing the ESM method did experience some constraints (Borrie \& Roggenbuck, 2001). Based on these experiences, the following guidelines have been offered for future using ESM research. First, researchers caution the use of ESM in certain situations which would be considered inappropriate. Events and facilities where technology is not widely accepted, such as an outdoor wilderness setting, would be one such situation. Also, in respect to the consumer's experience, the number of sampling times will need to be limited as to not disrupt the actual sport experience. The difficult question is whether or not more checks would produce different results, thus questioning the adequacy of the sampling level. Third, the repeated measures design requires an effort by respondents to report multiple times before, throughout, and after the event in order to complete the survey process. Often subjects fail to complete the entire process, creating a hole in the method and resulting in the survey being excluded from the research. 
Survey Design

The multi-dimensional aspects of a sport experience lead to a question of the most effective measures of analysis. A complete survey process involves a combination of both quantitative questions such as real time satisfaction (RTS) and qualitative such as post hoc satisfaction (PHS) questions (Stewart, 1998; Hultsman, 1998). This combination allows for a greater degree of innovative and adaptive analysis techniques. Real time satisfaction questions focus on that which is being experiences "right now" and PHS focuses on one's interpretation and evaluation of an experience after it has been completed.

The quantitative section would utilize a measurement tool similar to that utilized by the outdoor adventure experience which is comprised of a mood scale, a focus of attention scale, and a perception of competence and risk scale (McIntyre \& Roggenbuck, 1998). The mood scale is a seven-point semantic differential comprised of twelve bipolar adjectives used to describe moods. The focus of attention scale included a differential rating of the degree of focus on self, others, nature and task. For the purpose of the multiphase sport experience study, nature could be adapted to fit the specific sport event. This scale consisted of a stem "How much are you focusing on each of the following," and four items; "your own thoughts and feelings?", "other people round you?", "the environment?", and "the task you are carrying out?" Responses were measured on a ten-point scale varying from "Not at All" (0) to "Very Much" (10). One set of these scales was completed at each of five predetermined sights throughout the experience.

Qualitative research helps to unravel contradictory perspectives and underlying arguments, offering further insight into the study (McIntyre \& Roggenbuck. 1998). Therefore, a qualitative section would be included in the ESM process of a multiphase sport experience study. The qualitative section would involve personal written accounts of one or more of the phases of the sport experience. The purpose of these written accounts would be to gain deeper insights into the participants' feelings and perceptions during a particular phase. Through the use of personal written accounts in research conducted by McIntyre and Roggenbuck (1998), the 
complexity and variety of feelings and perceptions which characterized the experience were captured. The overall focus was on the meaning of the experience, how the experience was constructed and remembered. The process allows respondents to share characteristics of their experience that are not typically mentioned in literature, such as disappointment and frustration. Open-ended questions could also be incorporated to assess the participants' feelings about specific aspects of the multiphase sport experience.

\section{Data Analysis}

When analyzing the ESM data, there are two approaches that could be utilized. First, the data may be analyzed using each participant's response at each location as an individual data point. A second option would be to use the variations in participants' moods, focus of attention, and perceptions of satisfaction and compared them between locations. Satisfaction is defined as an act of judgment, a comparison of what people have to what they think they deserve, expect, or may reasonably aspire to. If the discrepancy in this comparison is small, the result is satisfaction. If the discrepancy in this comparison is large, there is dissatisfaction (Hultsman, 1998). Satisfaction differs from happiness. It is one's temporary positive feelings and morale at the moment, including the future-orientated optimism in one's life. Dissatisfaction does not necessarily imply an inability to cope with adverse conditions. It simply means there is larger discrepancy between expectations and aspirations compared to the reality of the experience. Just because desired outcomes and expectations do not match, this does not necessarily mean that fulfillment did not occur. Patterson, et al. (1998) described a qualitative analysis process that can be used to help to determine what individual statements reveal about the experience being studied. The system used attempted to identify dominant themes which seem to characterize the nature of participants' experiences and to present the different ways these themes were featured in their experiences.

Research in the multiphase sport experience phenomenon would give sport marketers the necessary information for looking 
beyond the onsite experience and creating a competitive advantage. Advances in technology have increased the opportunity to think outside the box when it comes to conducting this research. The Web, Wi-Fi, and Social Networking sites offer easy to use, acceptable forms of communication. When conducting research during online events, survey administration can easily be done during the event. Online ESM would also work effectively for sport events that are free for viewing online, such as the World Cup games.

Overall, the multiphase research process would use a combination of emerging technologies and ESM to survey participants during each of the five phases of the sport event experience. A blend of qualitative and quantitative information would be collected at specific non-intrusive intervals. This would allow for real time data collection and an opportunity for respondents to evaluate the immediate experience. Sample size for quantitative components would be dependent on the specific measures used, and would allow for accurate measures of reliability and validity. While validity and reliability of many scales has been proven through previous research application with recreation and leisure foci (Larson \& Csikszentmihalyi, 1983), additional evaluation is always needed. Specifically, confirmatory factor analysis and structural equation modeling could be used for establishing model fits and power of analysis. For qualitative components, sample size would be established based on the point of information saturation and redundancy of data collected.

\section{Recommendations and Conclusions}

Viewing sport events as a multiphase brand experience allows sport managers and marketers to better fulfill consumer satisfaction expectations. However, there are implications in not having complete control over all aspects of each phase. One example of this may be the traffic flow after an event. On the positive side, a multiphase approach opens up opportunities for additional revenue in each phase of the event consumption, and not just during the onsite event. In the first, anticipation, event marketers can look for better ties with television shows, offer live updates through the web 
using social networking sites, and renew the importance of pep rallies. In phases two and four, travel to and travel from, ideas such as group packages, radio shows, web updates, weather, parking, traffic, social identity through traveling with a group all foster brand community. In phase five, recollection, offering reflection opportunities through social networking sites, as well as gifts and memorabilia from the gift shop can help create a better experience and offer additional revenue streams.

Recognizing sport experiences as multiphase occurrences is necessary for the success of marketing to sport consumers. The experiences represented by this continuum are a package deal; one phase does not come without the other four. The continuum depicts a dynamic experience, one that evolves and matures across five phases. Because the experience continuously changes, changes in appraisals of the quality of the experience will change as one moves along the time-space continuum (Hultsman, 1998). Sport researchers must conduct studies in all phases of the event experience to better understand the need and wants of the sport consumer. By doing this, event managers can develop, maintain and market services that successfully oblige consumers. This allows sport organizations and event marketers to develop logical extensions, partnerships, cobranding opportunities, and lasting sponsorship relationships.

The sport mega event study conducted by Florek, et al. (2008) found that Germany, host country for the FIFA World Cup event, experienced a positive change in consumer evaluation from the anticipation phase to the recollection phase. Germany embraced the event opportunities to enhance images through this mega event through specialized customer service training for all staff involved in the event, as well as uniform coordination of all police, event volunteers, and railway staff. Event consumers did not only respond positively to the magical environment of the event but also to additional surrounding aspects (Florek et al., 2008).

Conducting international research on sport as a multiphase experience involves additional insight into the cultural differences on consumer behaviors in different countries. As this and other studies develop, cultural differences will need to controlled and considered. International sport research models should be cross validated in 
various participatory leisure sports contexts, and should be validated against behavioral and attitudinal aspects of participation. In addition, consumer culture should be among the variables considered for international communication and cross-culture research (Theodorakis \& Alexandris, 2008).

In conclusion, there is evidence that the sport experience is multiphasic. In each phase our consumers experience changing feelings, moods and perceptions. Sport marketers need to think about the full, transient experience that consumers engage in when consuming a sporting event. This paper serves the purpose of both raising the profile of multiphase sport experiences and informing future research directions. As the sport industry continues to prosper there is an increased focus on all phases of the event experience from anticipation, travel to, onsite experience, travel from, to the recollection phase. The multiphase research approach allows the organization an opportunity to provide a better, more complete satisfying service experience for the consumer in all phases of the sport experience. It also will allow marketers to evolve their event brands through additional ancillary and secondary service elements. Recognizing a sports event as a multiphase experience creates a competitive advantage for event managers and marketers.

Ultimately, this enables the sport marketers to develop and maintain strong brand equity, and to strategically outperform competitors and differentiate from the others to stay competitive. 


\section{References}

Burns, A. C., Biswas A., \& Babin, L. A. (1993). The operations of visual imagery as a mediator of advertising effects. Journal of Advertising, 22, 2, 71-85.

Borrie \& Roggenbuck (2001). The dynamic and multi-phasic nature of on-site wilderness experiences. Journal of Leisure Research, 33, 2, 202-228.

Burke \& Franzoi (1988). Daily routine. American Sociological Review, 53, 559-568.

Daniels, M., Loda, M. \& Norman, W. (2005). Always on my mind. Journal of Travel \& Tourism Marketing, 18: 3, 1-10.

Fairly, S. (2009). The role of the mode of transport in the identity maintenance of sport fan travel groups. Journal of Sport \& Tourism, Vol. 14, Nos. 2-3, 205-222.

Florek, M., Breitbarth, T. \& Conjeco, F. (2008). Mega event=Mega impact? Travelling fans' experience and perceptions of the 2006 FIFA World Cup host nation. Journal of Sport \& Tourism, Vol. 13, No. 3, 199-219.

Fridgen, J. (1984). Environmental psychology and tourism. J. Jafari and Pergamon Press Ltd., Annuals of Tourism Research, Vol. 11, 19-39.

Gump, B. \& Kulik, J. (1997). Stress affiliation and emotional contagion. Journal of Personality and Social Psychology, 72, 305-319.

Hammit, W. E., (1980). Outdoor recreation: Is it a multiphase experience? Journal of Leisure Research, 20, 2, 107-115.

Holbrook, M., Chestnut, R., Olivia, T., \& Greenleaf, E. (1984). Play as a consumption experience: The roles of emotions, performance, and personality in the enjoyment of fames. Journal of Consumer Research, Vol. 11, 728-739.

Howard \& Gengler, (2001). Emotional contagion effects on product attitudes. Journal of Consumer Research, 28, 189-201.

Hultsman, W. (1998). The multi-day, competitive leisure event:

Examining satisfaction over time. Journal of Leisure Research, Vol. 30, No. 4, 472-497. 
Koo, G. (2009). Examination of the causal effects between the dimensions of service quality and spectator satisfaction in minor league baseball. International Journal of Sports Marketing \& Sponsorship, 46-59.

Larson, R. \& Csikszentmihalyi, M. (1983). The experimental sampling method. New Dimensions for Methodology of Social and Behavioral Science, 15, 41-56.

Lin, C. \& Huang, H. (2009). Variable assessment of product benefits in consumer behavior using a means-end approach. Social Behavior and Personality, 37(5), 577-582.

Lutz, K., \& Lutz, R. (1977). The effects of interactive imagery and learning: Application to advertising. Journal of Applied Psychology, 62, 493-498.

MacInnis, D., \& Price, L. (1987). The role of imagery in information processing: Review and extensions. Journal of Consumer Research, Vol. 13, 473-491.

McIntyre, N. \& Roggenbuck, J. (1998). Nature/person transactions during an outdoor adventure experience: A multi-phasic analysis. Journal of Leisure Research, Vol. 30, No. 4, 401422.

Nawijn, J. (2010). The holiday happiness curve: A preliminary investigation into mood during a holiday abroad. International Journal of Tourism Research, 12, 281-290.

Neal, J., Sirgy, J., \& Uysal, M. (1999). The role of satisfaction with leisure travel/tourism services and experience in satisfaction with leisure life and overall life. Journal of Business Research, Vol. 44, 153-163.

Patterson, M., Watson A., Williams, D., \& Roggenbuck, J. (1998). An hermeneutic approach to studying the Nature of Wilderness Experiences. Journal of Leisure Research, Vol. 30, No. 4, 423-452.

Robbins, D., Dickinson, J., \& Calver, S. (2007). Planning transport for special events: A conceptual framework. International Journal of Tourism Research, Vol. 9, 303-314.

Ross, S. (2006). A conceptual framework for understanding spectator-based brand equity. Journal of Sport Management, 20, 22-38. 
Snepenger, D. (1987). Segmenting the vacation market by noveltyseeking role. Journal of Travel Research, Vol. 26, No. 2, 814.

Stewart, W. (1998). Leisure as multiphase experiences: Challenging traditions. Journal of Leisure Research, Vol. 30, Issue 4, 391-401.

Theodorakis, N. \& Alexandris, K. (2008). Can service quality predict spectators' behavioral intentions in professional soccer? Managing Leisure, Vol. 13, 162-178.

Vogt, C. \& Stewart, S. (1998). Affective and cognitive effects of information use over the course of a vacation. Journal of Leisure Research, Vol. 30, No. 4, 498-520.

Walker, G., Hull, B. \& Roggenbuck, J. (1998). On-site optimal experiences and their relationship to off-site benefits. Journal of Leisure Research, Vol. 30, No. 4, 453-471. 
The Journal of SPORT, 2012, 1, 55-90

(C) Kent State University

\title{
An Examination of NCAA Division I Football Bowl Championship Subdivision Department Revenues and Expenditures and Their Effect on Athletic Success in a Mid-Major Athletic Conference
}

\author{
David Ridpath \\ Ohio University
}

Drew Fattlar

Ohio University

\section{Athena Yiamouyiannis \\ Ohio University}

\begin{abstract}
Athletic department expenditures within National Collegiate Athletic Association (NCAA) Division I athletics are in many cases growing faster than the general university budget. Universities are spending millions on athletics, specifically in the sports of men's basketball and football, to achieve athletic success and to generate marketing exposure for the university. Typical spending comes in upgrading facilities and luxuries oftentimes justified to enhance winning, revenue generation, overall university exposure, enrollment, and fundraising. For this study, athletic and university success is defined as significant gains in these five aforementioned areas. The purpose of this study is to examine the effect increased expenditures have had on "mid-major" athletic programs (specifically those who are not affiliated with the College Football Bowl Championship Series) such as the Mid-American Conference (MAC) to see if those increases influence a positive or negative outcome on athletic and/or university success. The researchers found, in the case of the Mid-American Conference, that increased expenditures do not significantly increase athletic and or university success and often results in reductions in other sports programs and increases in institutional subsidies to cover increasing expenses. In addition, the researchers present potential areas of savings which might enable intercollegiate athletic programs to keep athletic programs rather than eliminating or reducing them to meet Title IX gender equity requirements or financial contingencies.
\end{abstract}


Within the United States, the National Collegiate Athletics Association (NCAA) is the primary intercollegiate athletics governing body for varsity sports at four-year colleges. Within the NCAA, there are three divisions (Divisions I, II, and III). Division I institutions typically place a greater emphasis on athletics compared to II and III and are permitted to offer the largest number of athletics scholarships per sport. Division I is further subdivided into Division I-Football Bowl Series (FBS) and Division I-Football Championship Series (FCS). The phrase "BCS conference" refers to a school's affiliation with one of the six major conferences whose conference champion receives a bid to a Bowl Championships Series (BCS) game in the sport of football (Bowl Championship Series, $2011^{1}$ FBS schools are generally more competitive, have larger budgets and oftentimes have more students than FCS schools, which is why FCS schools are sometimes referred to as mid-major programs as opposed to the major programs that can compete for the BCS title (Vedder, Villwock \& Denhart, 2009).

Athletic department expenditures at many Division I institutions are growing faster than the general university budget (Denhart \& Vedder, 2010; Litan, Orszag \& Orszag, 2003). The division featuring the largest budgets and most commercially competitive collegiate programs is NCAA Division I. The intercollegiate athletics budgets for Division FCS and FBS programs range from just under $\$ 20$ million annually to well over $\$ 100$ million annually (Vedder, et al., 2009). The purpose of this study is to examine the affect increased expenditures have had on mid-major athletic programs (specifically those who are not affiliated with the Bowl Championship Series) such as the Mid-American Conference (MAC) to see if those increases influence a positive or negative outcome on athletic and/or university success.

\footnotetext{
${ }^{1}$ The eleven FBS conferences are the: Atlantic Coast Conference (ACC), Big 12 Conference, Big East Conference, Big Ten Conference (Big-10), Conference USA (C-USA), Mid-American Conference (MAC), Mountain West Conference (MWC), Pacific-10 Conference, Southeastern Conference (SEC), Sun Belt Conference, and the Western Athletic Conference (WAC).
} 
The MAC was established in 1946 and currently features an East and a West Division for the 12 -member conference. A $13^{\text {th }}$ school, Temple University, has membership in the sport of football only. The East Division consists of the University of Akron, Bowling Green State University, the University at Buffalo, Kent State University, Miami University, Ohio University, and Temple University. Competing in the West Division is Ball State University, Central Michigan University, Eastern Michigan University, Northern Illinois University, the University of Toledo, and Western Michigan University (Mid-American Conference, n.d.). MAC schools have a total student population of 240,000 making it the third largest DI conference by enrollment (Mid-American Conference, n.d.).

The challenge for mid-major Division I colleges is to compete in the division on a much smaller budget which has been financially taxing for many members of the conference. For example, Eastern Michigan University (EMU), a school seven miles from the athletic powerhouse, the University Michigan uses $13 \%$ of its total university budget to subsidize athletics and the athletic department is over 90\% subsidized (Vedder, et al., 2009). In recent years mid-majors have been faced with greater inequality in revenue sport spending between themselves and larger schools (Denhart \& Ridpath, 2011) This is due to fixed costs associated with sponsoring programs, which make athletic department expenditures a higher percentage of the university's entire budget at smaller schools (Litan, et al., 2003, Sander \& Fuller, 2011). The revenue sports teams are generally considered to be the football and men's basketball teams, which receive the bulk of donation dollars and general fees appropriations at most institutions (Denhart \& Ridpath, 2011; Vedder et al., 2009) While these teams are considered to be revenue generators, often at mid-major colleges and even BCS institutions, their expenses outweigh the money they bring in and cause the athletic department to run a deficit, creating a continual need to be supported by student general fee and institutional support contributions (Berkowitz \& Upton, 2011; McCarthy, 2010). For example at Ohio University $\$ 13.5$ million of the roughly $\$ 18$ million dollar athletic department budget is funded by student general fees (Bernheim, 2007; Carrera, 2007; Denhart \& Ridpath, 2011; Vedder, 
et al., 2009). Though most non-revenue sports are unable to generate substantial revenue, they receive miniscule budget allocations compared to the two sports that receive the lion's share of the budget (Bergmann, 1991; Denhart \& Ridpath, 2011; Ridpath, 2011).

Recent athletic success by some mid-major programs has fueled a drive for similar situated schools to compete at the higher levels of both football and basketball ostensibly to generate revenue for the athletic department and to increase revenue and marketing capabilities for the university (Frank, 2004). On many occasions college basketball has produced a Cinderella team, generally known as an unexpected entrant that achieves far more than is expected from them by advancing through the 68 team NCAA men's basketball tournament further than predicted. While these teams do not win the overall tournament, their success in advancing into the later rounds is remembered as one of the underdog achievements of the year. One team recently in the spotlight as this past decade's mid-major overachiever was Gonzaga University which experienced success starting in the mid 90's (Potter, 2008). The fallout of their success has been coined the "Gonzaga Syndrome" which refers to other mid-majors' efforts to significantly step up the intensity of their focus on winning, which typically means spending more money on infrastructure and salaries (DeCourcy, 2007). The result of this increased intensity and impatience in creating success has been the unprecedented 52 coaching changes following the 2006 season ostensibly to raise the chances of winning. It was in that season that George Mason University made a stunning march into the Final Four as a no. 11 seed (ABC News, 2006). At end of the 2010-11 season there were 39 coaching changes in men's basketball at the NCAA Division I level (Siegel, 2011).

A similar consequence of winning likened to the "Gonzaga Syndrome" is the "Flutie Effect." The legend of this effect began in 1984 when Boston College's Doug Flutie threw a game winning Hail Mary pass to beat the University of Miami. In the following year applications to Boston College shot up as a result of their exposure. This increase established a scenario relating athletic success to the school's popularity and coined the term the "Flutie Effect" (Flutie Effect, 2007). Many universities hold on to the idea 
that successful athletic programs will create more interest and exposure for their university and therefore increase the quality of their applicant pool and there is some anecdotal evidence that this can influence these metrics (Frank, 2004; Vedder et al., 2010). For example the results of the Potter study (2008) appear to contradict this finding; their results showed that the SAT scores of the freshmen class at George Mason the year following their run to the Final Four were 25 points higher than the previous class. Research has yet to conclude that increases or selectivity in applicants are sustained in the long term due to a single event like the Flutie's pass; the effects are shown to last only one to three years at best (Potter, 2008).

However, the research results of Litan, et. al. (2003), appear to suggest that there is no correlation between athletic spending and greater SAT scores of incoming students which is often used as reasoning for increasing the quality of applicant pools. The athletic and commercial success experienced by these institutions, whether "major", or "mid major" is rarely sustainable or realistic to expect based on existing data and research (Frank, 2004; Litan et al., 2003). There are many teams that have been extremely successful one year, yet are unable to achieve anywhere near that success the next. Where there may be blips of success, the only thing that is sure to be sustained from year- to-year are the growing expenditures as athletic department spending at the NCAA Division I level, including schools defined as majors and mid-majors, is outpacing university spending by over 3\% and growing (Denhart \& Ridpath, 2011). The continual increase in spending at the Division I level is "justified" as a means to an end that results in high level marketing and revenue generation for the university (Vedder et al., 2009; Denhart \& Ridpath, 2011). However, with limited resources, this success is difficult to achieve and even harder to maintain. Yet, many universities are chasing that dream and using ever-increasing institutional subsidies to finance the operation (Frank, 2004). Some have even resorted to eliminating other sports, and doing so under the guise of gender equity compliance, when the likely reason is due to funneling money into football and men's basketball (Ridpath, Lawrence, Yiamouyiannis \& Galles, 2008). 
Seeing as there are only rare occasions where mid-major programs excel to the point that they are nationally competitive, such as Boise State playing in BCS games over the past few years, at what cost should these programs be funded-ostensibly to benefit the entire university? One aspect of this study will explore the cost/benefit of what some consider exorbitant spending on only a couple of athletic department teams. A look at how this spending has resulted in athletic success will be important in determining the benefits of such expenditures. This research will also explore whether these attempts to keep up with athletic programs defined as major/BCS affect the financial viability of the athletic departments that run the programs. The idea of keeping up with elite programs would involve spending more to attract recruits, support athletes, provide facilities, and field teams that are similarly competitive to larger opponents. As an unintended or possibly intended consequence is the elimination of many sport opportunities to use funds for women's sports under the guise of Title IX compliance.

\section{Title IX}

Many university administrations' defense of sport elimination is the need to comply with Title IX gender equity requirements and as a cost saving measure (Munoz \& O'Donnell, 2007). Title IX is a federal law (20 U.S.C. 1681-1688, 1972) that prohibits discrimination based on sex in educational programs and activities. Recent sport elimination controversies at Rutgers University, James Madison University, and the University of Delaware to name a few support this conclusion (Pearlman, 2011; Ridpath, et al. 2008). The gender equity mandate is exercised at any educational institution, public or private, that receives any form of federal funding (Women's Sports Foundation, 2008). One opinion is that this federal mandate is being used as a scapegoat by the universities so that they could avoid admitting that massive spending on football and men's basketball might be causing financial instability in athletic department's nationwide (Ridpath, et al. 2008). 
The University

While it is ultimately a university's decision to choose what sports to sponsor, it can be argued that universities should be held accountable for those that use student general fee allocations that directly support intercollegiate athletics and state tax dollars that directly and indirectly support athletic programs. Not all programs use both or one of these sources, but all programs not in the BCS and even some in the BCS use these fee sources to fund their athletic programs (Berkowitz \& Upton, 2011). This is based on the idea that the funneling of money into an athletic department for the purpose of generating a profit is a poor business decision and economically not feasible nor realistic (Denhart \& Ridpath, 2011; Vedder, et al., 2010). According to the Transylvania University economist Dan Fulks in 2010, just 14 of the 120 FBS athletics programs and none of the 97 schools in Division I reported making money from athletics, with median losses of more than $\$ 2.8$ million (NCAA report, 2010; NCAA, 2008). MAC school budgets range from almost $\$ 28$ million at Temple University to just over $\$ 10$ million at Eastern Michigan University (Examining the University Bill, 2011). This budget is dwarfed by the $\$ 100$ million plus budgets from the likes of the University of Texas and Ohio State University, institutions that MidAmerican Conference teams compete with directly in NCAA Division I (Carrera, 2007; Dexheimer, 2007). When these major athletic program budgets continue to grow at rates on average of $13 \%$ yearly over the past decade, the smaller programs are left behind, but they are still desperately trying to compete at the same level (Dexheimer, 2007; Vedder, et al., 2009). These factors contribute to what is known as the "arms race" in intercollegiate athletics (Frank, 2004). In other words, the larger schools' spending on facilities, operations, and coaching staffs grows upward, peer institutions and smaller schools feel compelled to try to match expenditures to remain competitive. However, the reality of remaining competitive is largely something that will not happen, yet schools continue to spend, often beyond it means (Grant, n.d.; Ridpath et al., 2008). 


\section{NCAA Financial Detail and Summary}

Based on the NCAA's projected revenues and expenses data, the NCAA's estimated revenue for each year from 2007-10 is on average \$564 million (NCAA, 2006; NCAA 2007a; NCAA 2008; Vedder, et al., 2009). Of the $\$ 564$ million in annual revenue, $\$ 508$ million was generated from Division I television and marketing deals. Another \$44 million comes from NCAA championships. Division I expenditures total $\$ 390$ million, or $69 \%$ of all expenses. D-II and III expenditures total on average $\$ 24.7$ and $\$ 17.9$ million in expenses respectively. A large portion of the revenue goes to fund championships in all three divisions and national office operations. In 2010, the NCAA signed a new contract with CBS Sports, Turner Sports, and TruTV which totals 14-year, $\$ 10.8$ billion dollars which now adds up to almost $\$ 700$ million dollars annually in total revenue for the entire NCAA (Sandomir \& Thamel, 2010).

The Knight Commission Report entitled, "A Call to Action," states in 2001 each win in the NCAA tournament had an overall value of $\$ 780,000$ for a school (KCIA, 2001). The money used to pay for the money units which contribute to the overall value is generated from the approximated $\$ 350$ - \$760 million the NCAA receives yearly over the life of the previous 11-year $\$ 6$ billion deal with CBS for the broadcast rights to the men's NCAA basketball tournament (Zimbalist, 2008; Glenn, 2007). A similar 11-year contract with ESPN to broadcast all of the other 20 NCAA championships besides football and basketball is worth $\$ 200$ million, or \$18.2 million per year (Glenn, 2007).

For CBS, the profitable part of this venture comes in the advertising revenue that is generated throughout the 67 televised games of the tournament (Sandomir \& Thamel, 2010; Spence, 2005). TNS Media Intelligence analyzes the data of television sponsorships including those of in the NCAA men's basketball tournament and BCS bowl games. According to their analysis, the advertising revenue earned from the NCAA men's basketball tournament reached $\$ 497$ million, generating a total of $\$ 2.73$ billion in revenue since 2000 (TNS Media Intelligence, 2007). The $\$ 497$ million from 2007 surpasses total revenue for the NBA, NFL, and MLB 
postseason tournaments. This number accounts for $75 \%$ of the advertising revenue generated by men's college basketball for the entire season. This ratio is essentially inverse for college football's revenue generation as $78 \%$ of football's revenue generation comes from regular season play. Overall, in the 2005-2006 season basketball generated $\$ 662$ million in total advertisement sales while football generated $\$ 506$ million in total advertising sales (TNS Media Intelligence, 2007).

Beyond the NCAA's tournament television contract, many conferences also have exclusive television deals (Ourand \& Smith, 2008). Ourand and Smith explain that most BCS conferences received around \$50 million or more for their 2005-2006 television contracts in football and basketball. The largest deal by far is the 25 year deal the Big Ten Conference has with Fox Sports where the Big Ten is projected to receive $\$ 2.8$ billion over the life of the deal (Ourand \& Smith, 2008). The newly configured Big 12 conference just inked a 13 year, 90 million dollar television deal with Fox Sports (Staples, 2011).

Universities utilize many other means for generating revenue. Ohio State University signed a $\$ 40$ million dollar contract for the naming rights to its basketball arena while the University of Minnesota garnered \$35 million to name its new \$288 million dollar football stadium (Wolf, 2007). Many universities do choose to retain the traditional stadium names rather than gaining corporate sponsorship. Some suggest future trends will follow the professional model of licensing the naming of stadium entrances (Walker, 2007). Other licensing ventures include collegiate apparel which is a booming $\$ 3.5$ billion industry thanks in part to the 29 million college alumni (Barnidge, 2008). The top apparel revenue generator in the 2005-2006 season was the University of Texas as they made $\$ 8.2$ million in revenue in the wake of their football national championship victory (Barnidge, 2008). Universities generate money through licensing the ability to sell apparel featuring the school's trademarks. The fee structure includes a flat fee charged up front to stores and royalty fees charged for each item sold (Barnidge, 2008; Mullin, Hardy \& Sutton, 2007). While only a select few universities make the big bucks, the enticing Cinderella stories that 
happen yearly have universities vying for their chance at the bigtime. A narrowing margin for error leaves universities willing to do just about anything to get and stay at the top (Associated Press, 2006; Munoz \& O’Donnell, 2007; Tublitz, 2008).

Data from the NCAA released in 2007 showed that only 22 of 313 D-I athletics programs were profitable after removing institutional support (Knight Commission on Intercollegiate Athletics [KCIA], 2007b). Goff opposed this sort of data stating that expenses incurred are inflated with accounting principles and that actually only $10 \%$ of schools are unprofitable. Skousen also claimed that many football programs can be profitable by properly reassigning indirect benefits to properly assess the contribution that a large scale football program creates (Skousen, 1988).

One significant contribution to the sustainability of athletic programs is the student general fee which is part of overall institutional support. Student fee aid is a portion of tuition from every student that is divided up amongst university programs. This amount of institutional support has been steadily rising, and currently averages $\$ 2.5$ million for the Football Bowl Subdivision. This amount is under $10 \%$ of the average institutional support versus revenue generated (KCIA, 2007a; Vedder, et al., 2009). Revenues are generated mostly through ticket sales, then alumni contributions, then conference distributions. On the expense side, expenses are generated mostly from salaries, then grants-in-aid, and then facility usages and maintenance expenses.

The NCAA states that approximately $95 \%$ of revenues are returned back to institutions in the form of services and direct payments (NCAA, n.d.). Some of these direct payments are based on sports sponsorship and the number of grants-in-aid given. For every sport over 13 sponsored by a school, the NCAA gives the school a direct payment of $\$ 22,000$. There are also direct payments from the NCAA based on the number of grants-in-aid awarded by the school. These payments are allotted through a point based system. Moving in 50 scholarship increments, an institution receives 1 point for each of the first 50 scholarship it offers, 2 points for each of the next 50 scholarship, 10 points for scholarship 101-150, and 20 points per 
scholarships awarded above 150. Each point results in a direct payment of $\$ 214$ (Brown, 2005).

The reason that so much effort is being put into developing and maintaining successful athletic programs is that the high stakes can result in huge rewards (Frank, 2004). Each year the Bowl Championship Series gives out over $\$ 142$ million to BCS bowl game participants (NCAA, 2007a). This is a 13\% increase from '05-'06 which vastly outweighs the $4 \%$ average growth. The NCAA also gives payouts to teams competing in the NCAA basketball tournament. The "money units" accumulate over a six year period resulting in a check to the conference at the end of the period. The amount is based on the number of appearances by a conference's teams and the number of rounds they advance through. A money unit is attributed to a team for each round of the tournament they play in; these units are valued between $\$ 150,000$ - \$175,000 (Glenn, 2007).

What is seen in the current state of NCAA athletics is a complicated, multi-billion dollar industry where winners are receiving massive compensation for their success, but in all likelihood are spending more. More and more universities are sacrificing other parts of their athletic departments to compete in the same spending arenas with other DI powerhouse football and basketball programs. One such example is Rutgers who dropped six sports to free up $\$ 800,000$ for the athletic program in 2006. Not surprisingly, the football team saw the greatest budgeting increase the following year. Though football for them continues to be a money losing operation, the university allows continued spending increases so that football can be the "front porch for the university" (Associated Press, 2006; Berkowitz \& Upton, 2011; Suggs, 2003).

Zimbalist reflects on this situation by saying that the possibility for success at Rutgers is there because of their geographic location and lack of competition in the area (only major collegiate football team in New York/ New Jersey area). A lack of success by the football team Zimbalist says will drain other sports (Associated Press, 2006). Even though Rutgers is geographically located to make a leap in football status with the hopes of creating a huge revenue source that to really compete at the same level as Michigan and Ohio State and even Louisville, they're really going to have to spend a 
large amount of money to even come close to accomplishing that goal (Associated Press, 2006).

The University of Alabama's hiring of Nick Saban as its head football coach illustrates the escalating costs associated with running Division I football programs. This $\$ 4$ million per year hire is one of the largest in college athletics and shows how much universities are willing to spend to be successful. $10 \%$ of the entire athletics department's $\$ 70$ million budget is spent on football coaches' salaries alone. In giving reasoning for such a large expenditure, athletic director Mal Moore says that Alabama is "able to do this, and I'm glad that we could" (Estes, 2007). Such actions are the basis for the claims of an ongoing arms race that has left many institutions struggling to keep up. Currently smaller divisions such as the MidAmerican Conference have coaches' salaries equating to $12 \%$ of their budgets compared to the $4 \%$ spent by other large DI institutions.

Women's sports continue to be underrepresented as female undergraduates make up $55.8 \%$ of the collegiate population while only $41.7 \%$ of athlete populations are represented by female studentathletes (Koller, 2010). Interestingly enough, these numbers had been growing throughout the 90's during the early stages of Title IX implementation, but have stalled since the year 2000 (Cheslock, 2007). We cannot be sure exactly why these numbers have slowed, but the increasing allegations of an arms race have occurred during this period of stalled growth.

A report by the NCAA was conducted to review athletic expenditures and revenues. It generated conclusions that support the idea that spending in intercollegiate athletics is out of control. The period of examination was from 2004-2006, a time in which the NCAA asked respondents to make changes to their financial reporting process (NCAA, 2008). Specific changes included review of submitted data by a third party, dividing revenue into those "generated" and those "allocated," and reporting revenues without the inclusion of allocated revenues (Berkowitz, 2008).

The major contribution made through this research was the adjusted accounting measures made to establish what revenue was generated or allocated. The revenue reported in previous years was a 
single sum of both sources of revenue. This single sum was misleading because allocated revenues, such as student fees or general fund monies, come directly from the university and not from outside sources. These allocated funds can be adjusted upward to make an athletic department appear self-sustaining, when in fact they are pulling money from educational programs to fund themselves. As Stan Nosek, vice chancellor of administration at the University of California-Davis stated "when some programs require more institutional support, it takes away from the core mission [of a university]" (Berkowitz, 2008, p. 1).

On average, D I-FBS institutions received $19 \%$ of revenues from allocated sources in 2004 . This number grew to $26 \%$ only two years later (Berkowitz, 2008). Zimbalist found flaws in the NCAA's data collection process, as the new process of reporting of revenues still included alumni contributions amid findings that contributions to sport are often associated with decreases in general giving to the university. Zimbalist also mentioned that the improved allocations of indirect expenses to the athletic program were "still not comprehensive." Zimbalist's example illustrated that if a university president were to spend $15 \%$ on athletics, $15 \%$ of their salary should be paid by athletics (Zimbalist, 2008). With these increasingly transparent measures in place it was found that the 19 profit generating schools for 2005-2006 averaged a surplus of $\$ 4.29$ million, while the other 100 programs lost on average $\$ 8.92$ million (Berkowitz, 2008). The average gap of $\$ 13.21$ million between those in surplus and those in deficit doubled since the 2003-2004 time period (Zimbalist, 2008). To make matters worse, a Jonathan and Peter Orzag study found that the average cost of athletic facilities is an additional \$24 million. This capital expense is not included with operating expense numbers (Zimbalist, 2008). The increasingly apparent struggles athletic departments are facing left Zimbalist to finish by saying "The day of reckoning is coming. It is time for college sports to sober up (Zimbalist, 2008, p. 1)."

Both Knight Commission reports assessed the problems associated with academic misconduct and the building arms race. In the 2001 report stated at more than 970 NCAA member schools, generated $\$ 3$ billion a year, but were spending $\$ 4.1$ billion in that 
same period (KCIA, 2001). More recent reports were even more sobering that at best for every one dollar made was at least a dollar spent (Litan, et al., 2003). The idea behind the arms race is that universities feel they must have the best facilities or spend the most on operating their programs to attract the best recruits. Once a rival university builds something better or spends more on an athlete, all peer universities feel the need to spend more to cover the new gap. This attempt to maintain the best programs leaves smaller, less financially viable athletic programs losing money. Litan, et al. (2003) found no evidence of an arms race, but their research did not include capital expenditures which are a main component of such a race.

\section{Success and Donations}

Athletic success has often been considered a catalyst for alumni donations. Common sense might seem to support this idea on the basis that alumni will give back if a team is doing well and has high prospects for the future. Recently researchers have been trying to determine if this idea is statistically true (Humphreys \& Mondello, 2007; Stinson \& Howard, 2007). Factors to consider when looking into donations are the two different kinds of donations, the difference in donation frequency and amount across universities, and the inconsistencies and short comings of information systems that gather donation data.

Restricted and unrestricted giving makes up the two different types of donations received by universities. Restricted donations are specifically earmarked towards a department by the giver. On the other hand, unrestricted donations are given to the university which then divvies up monies across departments. When analyzing donations given to universities, one must remember that there is heterogeneity across universities; this means more prestigious universities produce students that usually have higher salaries and are more likely to be able to give back (Humphreys \& Mondello, 2007). Another constraint in the research is that databases can be incomplete or give information with few details. For instance, restricted giving does not have information on which department it was donated to. The Council for Aid to Education estimates that \$.22 
of every dollar donated is earmarked to athletics. An initial claim that the most current research is looking into is Litan, et al. (2003) claim that increased operating expenditures along with other spending result in an increase in alumni donations.

Stinson and Howard's (2007) results were similar to those from Humphreys and Mondello (2007). Stinson and Howard found that athletic success affected donations for less prestigious schools, but only within athletics. Humphreys and Mondello had similar results that showed only that athletic success increased donations in restricted giving. Both agreed that athletic giving had negative effects on giving of donations to academics. Stinson and Howard found that athletic success had no effect on academic giving and mentioned that trends show that athletics are increasingly the beneficiary of additional giving which likely takes away from academic and other university coffers. Humphreys and Mondello worried more about the sustainability of programs that focused on success because for most it is so difficult to achieve. As they said, in referring to the money generated by current success, "a short-run phenomenon is not a long-run panacea."

\section{Theoretical Framework for Study}

With so much focus on the now multi-billion dollar college athletics industry, academic research has begun to focus greater attention on contributing factors to increased spending and allocation of funds. Two significant factors that will be discussed are often not related within academic research, but do have connecting ties. Distributive justice theory analyzes the decision making process that universities follow when deciding how to allocate funds. Other literature analyzes the effects that success has on donations to the university. Distributive Justice is intertwined with university giving because of the need to distribute these funds. In the current state of college athletics, distribution of funds is extremely important especially when considering how many schools are hoping to compete at a high level (Hums \& Chelladurai, 2007). 


\section{Distributive Justice}

Leading the majority of the scholarly work in intercollegiate athletics involving distributive justice is Mahony and Hums who have produced individual and team works. According to concepts of distributive justice, allocation of funds is determined based on three separate criteria which are equity, equality, and need. Hums' research shows that of administrators, women prefer equality distribution while men prefer need as a basis for distribution. Follow up research by Mahony and Breeding in 1999 surveyed students and student-athletes. The study found that equality was rated the highest but revenue sport athletes and males chose need. Mahony and Hums later found that the use of a need based system is usually considered the most fair by athletic directors, and is how most describe their distribution (Mahony, Hums, \& Riemer, 2002; 2005). At this point the authors questioned whether the same definition of need was being used by all members of the sample. The formal definition of need can be described as "those with less need more," and need determinations are used when goals include personal growth and the survival of the group (Deutsch, 1975).

Allocations of funds are generally a significant indicator of how an athletic program is run. The goals of the program can usually be determined based on how money is distributed. If need is defined as giving to those that have less, circumstances resulting in a lack of financial resources for certain groups should be reversed by supplementing that program. Instead what we see is further support for revenue sports that already receive much of the distribution. (See Figures 1-4). Mahony et al. (2004) study finds that athletic directors see football as the neediest sport even though it is typically the best funded and is allotted the most resources. This would indicate that a need based model is not followed and that personal growth and survival of the group are not primary objectives. It would also appear that in actuality a corporate model is being used (Mahony et al., 2002; 2005). Running such a model is considered taboo in the non-profit academic world.

This paper analyzes whether the theory of distributive justice is used in funding athletic programs. Is it based on need or is it based on profit potential and alleged benefit to the university, or is need 
defined in the mind of those decision makers as the team that ostensibly has the most potential to make a profit and appease the public? This study suggests that need is not one of the primary factors used by athletic departments in the MAC when developing strategies to distribute funding, rather it is greater funding of sports that have potential to generate revenue, but rarely do.

\section{Hypotheses}

The research question is divided into two separate examinations. The first approach is to examine the relationship between revenues and expenditures in the sports of football and men's basketball as compared to the athletic success in those programs (Examination 1). The second approach is to examine the relationship between athletic department expenditures and the financial viability of the athletic department (Examination 2). The variables that are produced by the research questions include athletic department revenues and expenditures, athletic success in revenue sports, and financial viability.

The hypothesis $\left(\mathbf{H}_{\mathbf{1}}: \boldsymbol{\rho}_{\mathbf{E S}}=0\right)$ pertains to Examination 1 and is meant to determine the relationship between athletic expenditures and athletic success. This null hypothesis states that there is no relationship between the amount of money spent on operating revenue sports and the success that that the teams achieve.

Examination 2 is an exploratory look at the growing use of allocated revenues within a small population that will serve as the examination of financial viability via public financial records made available by several Mid American Conference institutions.

\section{Methodology and Analysis of Data}

\section{Examination 1}

For Examination 1 the revenue and expenditure data were gathered from the Chronicle of Higher Education's Gender Equity database. The information supplied by the Chronicle of Higher Education's Gender Equity database was used to form Database 1. A sample size of 12 was created by using the Mid-American Conference as the population. Athletic success data is gathered from 
ESPN's website (ESPN, 2007b). The data were then entered into SPSS 15.0 for analysis. The relationship between expenditures and athletics success was tested using a Pearson Correlation test. This test determined if expenditures are related to actual athletic success. A rejection of the null hypothesis would show that there is significant correlation between the amount of money spent and the resulting athletic success, as defined in this study.

The measure of success was created by ranking winning percentages from in-conference competition. The football and men's basketball standings from the MAC regular season were individually used to develop rankings for each sport. The rankings were developed by first giving the MAC champion a one (1) ranking, in football only the MAC championship game runner-up was given a two (2) ranking, and then proceeding to give subsequent rankings to those with the next highest winning percentages. The number one ranking is important because it means the team will receive either an automatic bid to a bowl game for football or the NCAA tournament for basketball. Other MAC teams may receive a bid in that year, but it is not guaranteed. Teams with tied winning percentages received matching rankings, and the next best team would receive a ranking behind the multiple spots allocated to the teams that tied (e.g. if Ohio University and Bowling Green State University each receive a three ranking, the next best team would receive a 5 ranking). This data was available from the 2002-2003 seasons to the 2005-2006 seasons, allowing for 4 periods of examination. The researchers restricted the data to these years due to the consistency and availability of reports from the institutions that varied in dates and for completeness allowing for a more accurate and consistent assessment.

\section{Examination 2}

Due to the lack of specification in items contributing to the revenues and expenditures within the Chronicle of Higher Education's Gender Equity database, which made up Database 1, secondary measures were performed to make more exploratory searches into the true nature of expenditures and revenues within the MAC. Database 2 is comprised of financial information gathered 
through Freedom of Information Act (FOIA) requests that were sent to the General Counsels of all MAC schools. The original request asks for specific financial information relating to athletic department expenditures from fiscal year 2000 through the present. Schools within the NCAA complete worksheets and could potentially provide the worksheets used to electronically provide the Equity in Athletic Disclosure Act (EADA) filings that are sent to the Office of Postsecondary Education to be compiled in the EADA database. This is the same database that is the source of data for the Chronicle of Higher Education's Gender Equity database. The filings that must be sent to the Office of Postsecondary Education provide a much deeper look into the expenditures and revenue generation of the department than what ends up being conveyed in the EADA or Chronicle of Higher Education's Gender Equity database. The EADA filings are currently the best data source to use because of the comprehensive information that they provide.

The FOIA data gathering resulted in receiving complete data for the 2000 reporting year through the 2007 reporting year from two schools. The researchers also restricted the data to those years due to the consistency and availability of reports from the institutions. Two other institutions supplied seven periods of usable data, while another provided 5 periods of usable data. A sixth institution provided data that was not in the EADA filing format, but contained data that was able to be used in certain measurements. Due to the varying levels of usable data each measurement includes a note on what the population size was. Also, because the data has various missing values and a small population, median measurements accompany the mean measurements in order to eliminate outliers that could significantly affect the small population size. The exploratory measures that were conducted through Database 2 involved ratio analysis of the available variables.

\section{Results}

In testing the first hypothesis for each year individually, Examination 1 found that football expenditures from the 2003-2004 season were significantly related, at the .01 level, to the success 
attained. The following season had significant correlation to the .05 level. The 2002-2003 season and 2005-2006 seasons found no significant correlation between success and the amount spent to attain it. Although not significant, the 2005-2006 season showed weak tendencies to be correlated with success.

The Pearson Correlation test found that throughout the duration of the testing period football expenditures had a significant relation to the success attained. By spending more, greater success was generated. The scatter plot (Figure 1) shows that a team who spent above $\$ 4,000,000$ dollars on average continually remained one of the top three most successful teams in the conference. That amount is roughly $\$ 350,000$ more than what the fourth most successful team spent. There were no findings of a significant relationship between the success of the football teams and revenue generated.

During individual seasons over the four season period, in men's basketball there was no correlation between expenditures and success. As a whole, during the test period success did not significantly relate to expenditures. For the schools measured, there was also no correlation between success and revenue generation. The results suggest that during the assessment period, there was no correlation between individual athletic department expenditure variables (i.e., men's total athletic aid expenditures, men's total recruiting expenditures, or men's total coaching salaries) and the success of the football or basketball team. Note these variables were the overall budgets which include all male sports teams' expenditures. While it would be more helpful to use sport specific expenditures for testing, they were not available. The expenditures though are made up in large part by the revenue sports whose success they were compared against. 
Figure 1-Scatterplot of football expenditures and the correlation with football ranking in the MAC

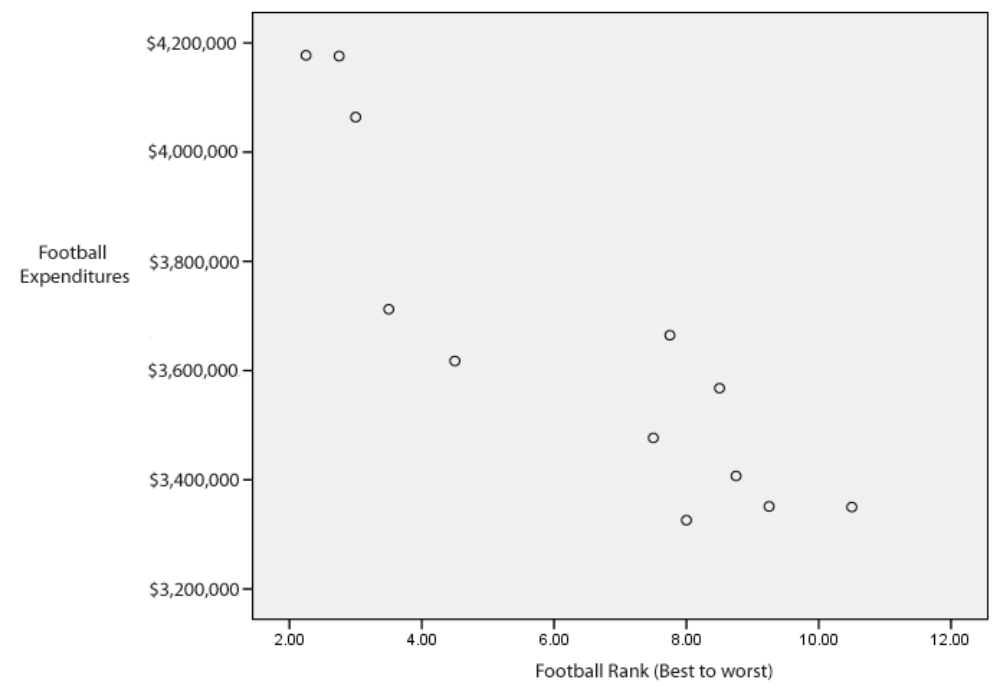

Testing of the hypothesis showed a rejection of the null hypothesis for the sport of football. Teams with greater success were shown to have greater funding. The lack of specificity in the operating expenditure variables did not allow for complete testing of what operating expenditures most significantly relates to success. For men's basketball, there was no correlation between winning and the amount of money used to fund the competing teams; therefore the null hypothesis as it relates to men's basketball was rejected.

The exploratory data analysis from Examination 2 found increases in several significant areas. Data showed that the average increase of student fees and institutional support was $11.96 \%$ per year with a median increase of $7.48 \%$ per year $(\mathrm{N}=6)$. The combination of student fees and institutional support is what is currently being referred to as allocated revenue. Another measure from this data set found that throughout the sample period $72.52 \%$ of all revenues were generated through allocated revenues, the median value was $72.05 \%(\mathrm{~N}=5)$. In the 2003-2004 reporting year the five institutions in the sample averaged $74.26 \%$ of expenses being paid by allocated revenue. In that same reporting year the national average was $26 \%$ (Figure 2). 
Figure 2-Percentage of Revenue-Generated and Allocated, MAC v. National Average

\section{Percentage of Revenue Generated and Allocated (MAC Average)}

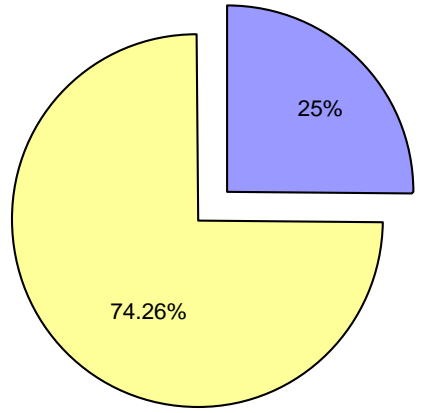

$\square$ Generated Revenue $\square$ Allocated Revenue

\section{Percentage of Revenue Generated and Allocated (National Average)}

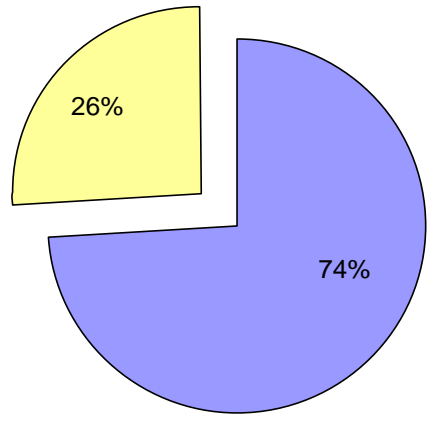

*Reporting year 2003-2004

In looking at increases in athletic department expenditures against increases in total university expenditures it was found that athletic department expenditures increased by an average of $16.33 \%$, median of $10.7 \%$, while total university expenditures averaged increases of $2.99 \%$, median of $3.5 \%$ ( $\mathrm{N}=4$ for both measures). On a yearly basis, the deficit created when allocated revenues are not included in total revenue figures is growing at an average rate of $16.01 \%$ (Figure 3 ). The average deficit for the 2005-2006 reporting year was $\$ 12,674,475$ which is $42 \%$ above the $2005-2006$ national 
average of $\$ 8,920,000$ (Figure 4). It should be noted that the MAC is already included in that national average, and that it can be assumed that the MAC members' inclusion already skews the average upward.

Figure 3-Average Deficit Growth

Avg. Year Over Year Deficit Growth

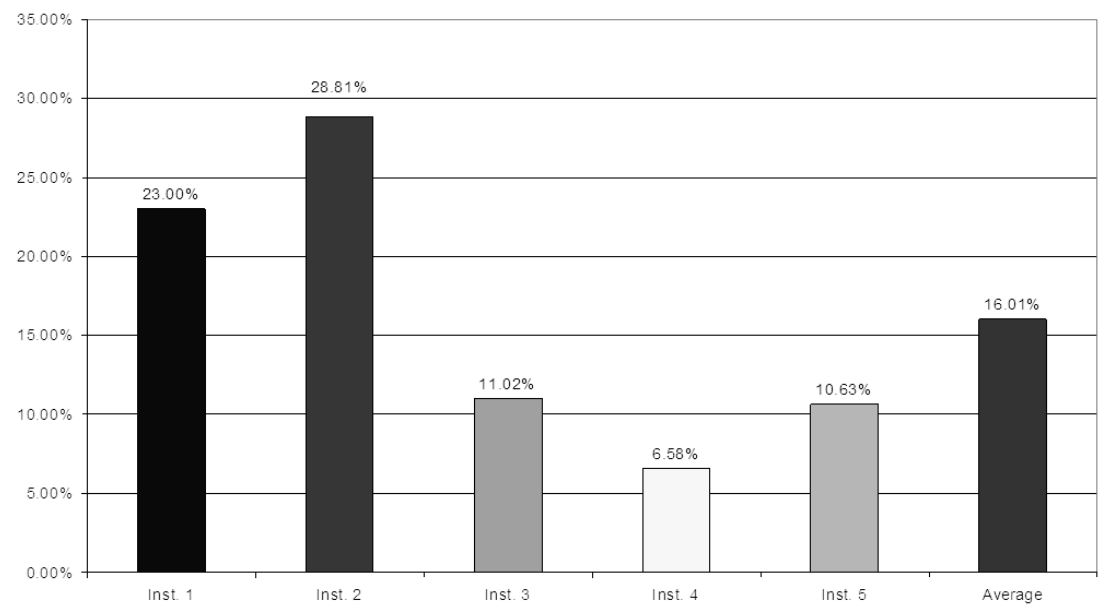

Figure 4-MAC Deficit Increase per year

Deficit Increase Per Year (from 1999-2000 to 2006-2007)

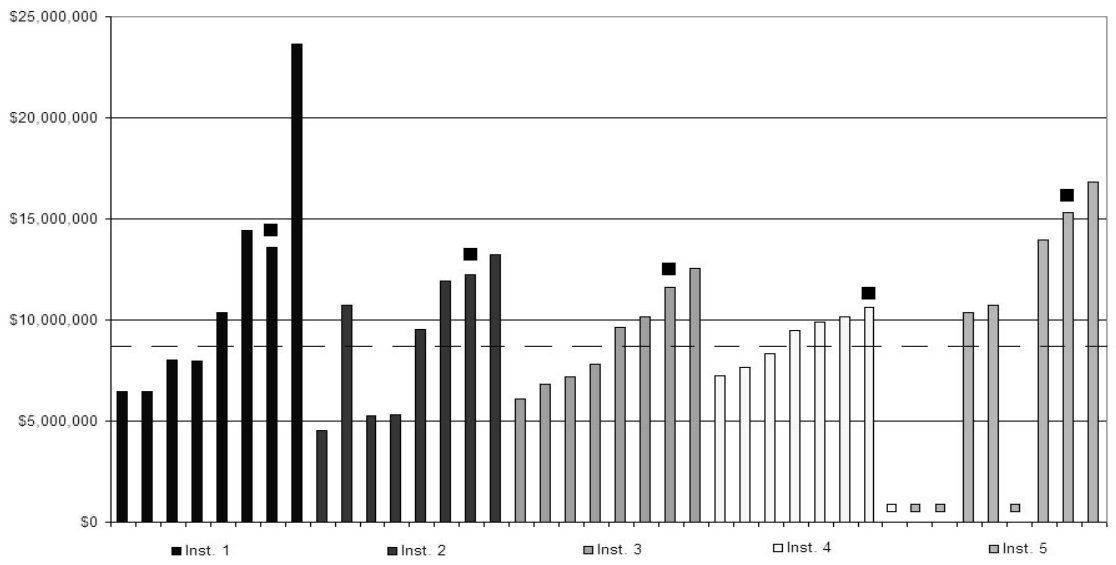

*Bars with black boxes above them denote the 2005-2006 reporting year; the dashed trend line denotes the $\$ 8.92$ million average deficit produced by the 100 universities whose athletic departments ran deficits during the 2005-2006 reporting year. 
Skousen (1988) and Goff (2000) have spoken out about the current measuring of total expenditures stating that it is not accurate because athletic aid is a non-cash expense. By taking athletic aid out of the total expenses the five institutions when taken together still have an average deficit of over $\$ 9$ million dollars per year.

\section{Conclusions and Recommendations}

The NCAA has increased transparency starting with its 2004-2006 Revenues and Expenses of Division I Intercollegiate Athletics Programs Report, but it is not enough. The Office of Postsecondary Education needs to make all of this data available to the public through their EADA database while the NCAA increases transparency. The select summaries of revenues and expenditures are not sufficient and inconsistent in format.

The NCAA also needs to continue its standardization of reporting measures. The lack of standardization in the past is a significant contributor to the limitations of this study. Instead of taking small, incremental steps towards standardization, the NCAA should make a large investment in creating acceptable reporting principles in the way that public corporations have standardized their accounting procedures. Such a change could be expensive and difficult for NCAA member institutions, but the affect would be the establishment of accountability for university financial reporting measures. The standardization would also provide transparency to the real expenses of intercollegiate athletics. Without government intervention, which seems to have become a recent catalyst for change in American athletics, it is the responsibility of the NCAA to use their power and be the one taking steps towards reformation. NCAA reformists should make increased transparency a primary factor in their suggestions for changes in the intercollegiate athletics system. Increased transparency will be a key factor in developing research that can assess the true cost of intercollegiate athletics.

Based on the review of financial data during the specified time period, MAC schools substantially increased athletics expenditures and the annual athletics percentage increase $(16 \%)$ far outpaced the increase in overall university expenditures (3\%). Substantial athletics increases on a yearly basis should be cause for concern at universities. Previously athletics budgets were masked 
with allocated revenues which hid the problem. Through this examination a better picture of revenues and expenditures is disclosed. When the athletics budget of these programs is increasing at a higher rate annually compared to the academic budget of these institutions, the alarm should sound. This is clearly not sustainable long term. The core mission of a university is to provide education, and in recent years schools have been spending at least \$10 million dollars on "ancillary/auxiliary" programs such as athletics. Certainly there are many benefits to intercollegiate athletics, but at what cost? The rate at which these expenditures are increasing is alarming and diminishing the financial viability of MAC athletic departments. The institutions simply will not be able to sustain such increases in the long term.

Examination 1 showed that the cost of success for football was in excess of $\$ 4,000,000$ of operating expenditures per year. This was an average over a four year period, so it is conceivable that this figure is currently much higher when factoring in the substantial increases in expenditures in recent years. Often the reasoning behind increased funding to these programs is the need to succeed, and the translation of that success into revenue generation in football and men's basketball. This study found that success does not translate into revenue generation. It is difficult to say why a relationship between basketball expenditures and success did not hold as it did for football. The limited time period in which the study was conducted could have played a role. A longer period of study could possibly show that greater expenditures result in more success. Also, the nature of competition in the MAC could have played a role. In looking at different conferences better known for basketball prestige, the relationship between expenditures and success may be more apparent.

The finding that success does not translate into increased revenue generation in the MAC is very important as this is often a reason for increased spending in these sports. This idea was discussed extensively in previous sections with examples of the successful outliers like Gonzaga and Boise State. The two schools' ability to overcome their mid-major status and excel on a national stage is something that many other mid-majors are trying to emulate. Should a school reach that status, they are able to enter into high 
paying bowl games or progress through the NCAA tournament and earn revenue associated with that progression. The ancillary benefits of increased exposure for the university and the possibility of increases in enrollment are also highly touted as major benefits to the expenditures made because of athletics, but not significantly supported by empirical research, including this study. Some university leaders justify the increase in dollars to athletics and the elimination of other sports teams by saying that the university is using these major sports as the "front porch" of the university. The "front porch" mentality seems to mean that sports are the easiest way to nationally advertise and draw attention to the school. Based on the data collected, it appears MAC institutions as a whole are spending over $\$ 100$ million dollars a year on non-core programs that have been essentially justified as advertising expense. Regarding the front porch concept, more research is needed to better understand the impact and degree that differing variables have in regard to media exposure and national attention. Front porch concepts aside, based on the results of this current study, the data suggest that the success that MAC schools may achieve does not result in revenue to match what has been spent.

In Examination 2, the difference between the median and mean shows a great deal of variance in allocated revenues in MAC schools. The variance shows how unsure many schools might be as to what their total expenditures will be for a given year. One school provided a variance analysis that described exactly how such instability could occur. In that given year the university received a bid to a minor football bowl game which they accepted. Even though the school earned $\$ 300,000$ for their appearance in the bowl game, the school lost hundreds of thousands of dollars more than that through their participation. The charter flight that the team took to the game cost $\$ 162,000$ alone; the school also spent $\$ 81,000$ on "championship items" (Denhart \& Ridpath, 2011). Other helpful insights into athletic department operations were provided through this report. For instance, a debt from the lowering of the football field several years prior resulted in a $\$ 477,000$ charge in 2007 . The university's explanation for this charge was that donations expected to pay for the capital project had not materialized. It is interesting that donations to a football team that just made it to a bowl game 
would not materialize; it would appear this situation opposes Stinson and Howard's (2007) findings that success results in greater restricted giving at less prestigious academic institutions. Another insightful piece of information supplied by the report became a prime example of creative accounting in intercollegiate athletics. The document showed that part of the proceeds of an internet service provider contract were placed in ticket sales revenue so that the program could meet the NCAA's 15,000 sold tickets requirement for the annual football certification process. Much like Zimbalist talked about, the financial data provided by institutions requires greater scrutiny. Until greater transparency is available, these numbers must be used with caution.

MAC schools have been spending more to remain competitive within the conference. Is this justified? Analysis of the data showed this to be true for football team expenditures. Most of the money used to fund these sports is coming directly out of the pocket of students, and the amount being taken continues to rise at an alarming rate. With economic hardships causing many states to make cuts to education spending, it becomes increasingly harder to justify such spending on athletic programs at all NCAA member institutions (Lav \& Hudgins, 2008). With such monumental price tags, the idea of developing national prominence through sporting program should be revisited. Only the most highly funded programs and the luckiest mid-majors are able to contend for a spotlight that has proven may provide short term benefits to enrollment, if any benefit at all, and exposure for a university. University leaders (presidents, athletic directors, and trustees) are supporting such plans to fuel the cycle of athletic expense increases with tax payers' dollars and students' tuition fees. Is this truly in the best interest of the students, the taxpayers, and the institution? The authors believe that in light of the current economic climate, a need to revisit institutional priorities is warranted.

\section{Limitations}

The limitations of this research are primarily based on the accuracy and availability of the data. The Chronicle of Higher Education's Gender Equity database took its information from EADA reports which were filled out by schools with varying 
accounting procedures. The difference in accounting procedures has had researchers speculate that many of the figures are not entirely accurate. Zimbalist once stated considering the purposes of discerning the true financial status of I-A athletic programs, the numbers and conclusions from the EADA reports were unenlightening (Zimbalist, 2008). This reference does not necessary mean that the data is totally useless; it is more likely Zimbalist is referring to universities tendencies to not fully record all expenditures properly.

The difference in accounting measures at universities cause certain expenditures to be allocated differently. This means that some expenditures were sizably larger at one institution versus another. In other cases a university appeared to switch accounting measures from one year to the next. In these cases a certain line item would be blank one year, then in the following year it would suddenly be a large expenditure. Such switches in accounting measures created gaps in the data. Other gaps in the data were formed, specifically in Examination 2, because universities simply failed to send the correct reports. On occasion a university would send data from reporting years 2003, 2005, and 2006, but skip reporting year 2004. This hindered analysis of the already limited population size in Examination 2.

Another limitation is the subjective success measure given to football and men's basketball in Examination 1. Due to tied records, many universities received matching rankings. The in-conference schedule for the two sports were limited, for football the teams may only play 6 or 7 in-conference games. This greatly increases the chance of having multiple teams tying with the same record. In order to help separate teams, the 1 and 2 rankings were given to those football teams that went to the MAC Championship game. This helped to validate the top ranked football teams, but left the middle and lower rankings more questionable.

The limited population in Examination 1 may have hindered the ability to establish a correlation in certain areas. Had the sample size been bigger and the testing period been longer, it may have been possible to find a significant correlation between variables such as basketball success and expenditures. The MAC does not contain any perennial basketball powerhouses so if future researchers add other 
schools to the population size, they should be similar mid-major programs.

\section{Future Research}

As the use of the NCAA's new accounting standards allows for more years of data to be compiled, useful year to year comparisons can be made. This sort of comparison will allow for the validation or rejection of what was found through this research. With the help of this more useful data, greater in-depth analysis will be possible and give increased insight into the true stability of intercollegiate athletic departments. Further research could use the approach that this research took in separately analyzing conferences. Analyzing DI-A as a single group can be misleading due to the vast differences between the upper and lower limits of the population. In order to properly conduct future research, uniform financial reports should be used. The requesting of one specific report from each school will help to ensure the credibility of the data and at least somewhat similar accounting measures. 


\section{References}

ABC News. (2006). George Mason Final Four shocker. Retrieved February 18, 2011, from http://www.abcnews.go.com/GMA/ESPNSports/story?id=17 90388

Associated Press. (2006). Rutgers invests in football but cuts other sports. Retrieved November 2, 2010, from http://sports.espn.go.com/ncf/news/story?id=2667334

Barnidge, N. (2008). Sports merchandising lucrative. Savannah Morning News. Retrieved March 11, 2011, from http://savannahnow.com//node/437745

Bergmann, B. (1991, Jan-Feb). Do sports really make money for the university? Academe. 77(1), 28-30.

Bernheim, L. (2007). Recommendations for general fee spending differ from distribution. The Post. Retrieved January 18, 2011, from

http://www.thepost.ohiou.edu/Articles/News/2007/10/29/219 $\underline{74 /}$

Berkowitz, S. (2008). Few athletics programs in black; most need aid. USA Today. Retrieved May 19, 2011, from http://www.usatoday.com/sports/college/2008-05-16financial-study_N.htm

Berkowitz, S. \& Upton, J. (2011, June 28). Rutgers athletic department needs fees, funds to stay afloat. USA Today. Retrieved July 3, 2011 from http://www.usatoday.com/sports/college/2011-06-28-rutgersathletic-department-subsidies_n.htm

Bowl Championship Series. (2006). The BCS is ... Retrieved January 18, 2011, from http://www.bcsfootball.org/bcsfb/definition Brown, G. (2005). APR 101. Retrieved May 28, 2011, from http://www2.ncaa.org/portal/academics_and_athletes/educati on_and_research/academic_reform/articles.html

Carrera, K. (2007, January 27). Athletic cuts could save \$685,000. The Post. Retrieved March 8, 2011, from http://www.thepost.ohiou.edu/Articles/Sports/2007/01/25/17 $\underline{227 /}$ 
Cheslock, J. (2007). Who's playing college sports? Retrieved February 15, 2011, from http://www.womenssportsfoundation.org/cgibin/iowa/issues/disc/article.html?record=1201

DeCourcy, M. (2007). Blame it on Gonzaga. Sporting News, 231(18), 55.

Denhart, M. \& Ridpath, B. (2011). Funding the arms race: A case study of student athletic fees. A Report from the Center for College Affordability and Productivity. Washington, DC.

Denhart, M. \& Vedder, R. (2010, April). Intercollegiate athletic subsidies: A regressive tax. A Report from the Center for College Affordability and Productivity. Washington, DC.

Deutsch, M. (1975). Equity, equality, and need: What determines which value will be used as the basis of distributive justice? Journal of Social Issues. 31, 137-149.

Dexheimer, E. (2007, September 30). The Longhorn economy. Austin American-Statesman. Retrieved March 7, 2011, from http://www.statesman.com/sports/content/sports/stories/longh orns/09/30/0930utsportsmain.html

ESPN (2007). NCAA Division I-A football standings. Retrieved March 10, 2011, from http://sports.espn.go.com/ncf/standings

Estes, G. (2007). Football salaries take 10 percent of Tide sports budget. Press Register. Retrieved September 24, 2010, from http://www.al.com/sec/mobileregister/index.ssf?/base/sports/ 1189761325208790.xml\&coll=3

Examining the university bill. (2011). Retrieved April 14, 2011 from http://et.kent.edu/jmc40004/fees/

Flutie Effect. (2007). The Economist. Retrieved March 7, 2011 from http://www.economist.com/blogs/freeexchange/2007/01/fluti e effect.cfm

Frank, R.H. (2004). Challenging the myth: A review of the links among college athletic success, student quality, and donations. Retrieved March 28, 2011, from http://www.knightcommission.org/about/white_papers/frank report/. 
Glenn, D. (2007). NCAA bubble can be costly. Retrieved March 1, 2011, from http://www.wral.com/sports/blogpost/2498926/

Goff, B. (2000). Effects of university athletics on the university: A review and extension of empirical assessment. Journal of Sport Management. 14, 85-104.

Grant, C. (n.d.). Title IX / gender equity videos (Video Recording). Retrieved February 25, 2009, http://ncaa.org/gender_equity/video/

Humphreys, R.D., \& Mondello, M. (2007). Intercollegiate athletic success and donations at NCAA division I institutions. Journal of Sport Management. 21, 265-280.

Hums, M. A. \& Chelladurai, P. (1994). Distributive justice in intercollegiate athletics: The views of NCAA coaches and administrators. Journal of Sport Management. 8, 200-217.

Knight Commission on Intercollegiate Athletics. (2001). A call to action. Retrieved May 18, 2011, from http://www.knightcommission.org/about/reports/category/A \%20Call\%20to\%20Action/

Knight Commission on Intercollegiate Athletics. (2007a). Changes in NCAA financial data collection and reporting: A new beginning. Retrieved May 28, 2011, from http://www.knightcommission.org/images/uploads/Financial Presentation05_07final.ppt

Knight Commission on Intercollegiate Athletics. (2007b). Knight Commission urges presidents to show strong support for academic reforms. Retrieved May 25, 2011, from http://www.knightcommission.org/students/item/knight_com mission_urges_presidents_to_show_strong_support_for_acad emic_refo/

Koller, D.L. (2010, December). Not just one of the boys: A postfeminist critique of Title IX's vision for gender equity in sports. Connecticut Law Review. 43(2), 403-455.

Lav, I.J., \& Hudgins, E. (2008). Facing deficits, many states are imposing cuts that hurt vulnerable residents. Retrieved June 4, 2011, form http://www.cbpp.org/3-13-08sfp.htm\#_ftnref4

Litan, R.E., Orszag, J.M., \& Orszag, P.R. (2003). The empirical effects of collegiate athletics: An interim report. Retrieved 
March 28, 2011, from

http://www.ncaa.org/library/research/athletic_spending/2003/ empirical_effects_of_collegiate_athletics_interim_report.pdf

Mahony, D., Hums, M. \& Riemer, Harold A. (2005). Bases of determining need: perspectives of intercollegiate athletic directors and athletic board chairs. Journal of Sport Management. 19, 170-192.

Mahony, D., Hums, M. \& Riemer, Harold A. (2002). Distributive justice in intercollegiate athletics: Perceptions of athletic directors and athletic board chairs. Journal of Sport Management. 16, 331-357.

McCarthy, M. (2010, September 21). Students are unaware of usage of fees; athletics a low priority. USA Today. Retrieved April 12, 2011 from http://www.usatoday.com/sports/college/201009-21-students-usage-fees_N.htm

Mid-American Conference. (n.d.). Quickfacts. Retrieved May 21, 2009, from http://macsports.com/ViewArticle.dbml?DB_OEM_ID=9400\&KEY= \&ATCLID $=323241$

Mullin, B., Hardy, S. \& Sutton, B. (2007). Sport Marketing: $3^{\text {rd }}$ Edition. Human Kinetics: Champaign, Il.

Munoz, M., \& O’Donnell, M. (2007, January 25). Title IX concerns cited in dropping of sports. The Post. Retrieved March 6, 2011, from http://www.thepost.ohiou.edu/Articles/Sports/2007/01/25/17 $\underline{226 /}$

NCAA. (n.d.). About the NCAA. Retrieved May 21, 2010, from http://www2.ncaa.org/portal/about_ncaa/

NCAA. (2006). Revised budget for fiscal year ended August $31^{\text {st }}$, 2007. Retrieved May 22, 2010, from http://www1.ncaa.org/finance/2006-07_budget.pdf

NCAA. (2007a). Five year summary of revenue distribution. Retrieved May 26, 2010, from http://www1.ncaa.org/membership/postseason_football/2006 -07/5_yr_summary_rev_dist.pdf

NCAA. (2007b). NCAA membership report. Retrieved May 22, 2010, from 
http://www2.ncaa.org/portal/media_and_events/ncaa_publica tions/membership/index.html

NCAA. (2008). 2004-06 NCAA revenues and expenses of Division I intercollegiate athletics programs report. Retrieved May 19, 2009, from

http://www.ncaapublications.com/ProductsDetailView.aspx? $\underline{\text { sku=RE2008\&AspxAutoDetectCookieSupport }=1}$

NCAA Report (2010, August 23). NCAA report: Economy cuts into sports. Retrieved April 10, 2011 from http://sports.espn.go.com/ncf/news/story?id=5490686

Ourand, J., \& Smith, M. (2008, March 3). Big Ten could reap \$2.8B from network deal. Sports Business Journal. Retrieved March 11, 2010, from http://www.sportsbusinessjournal.com/index.cfm?fuseaction $=$ article. main\&articleId $=58254 \&$ requestTimeout $=900$.

Perlman, J. (2011, January 21). Delaware cuts their cross country program, loses a beloved coach. SI.com. Retrieved April 9, 2011 from

http://sportsillustrated.cnn.com/2011/writers/jeff_pearlman/0 1/20/delaware.cross.country/index.html

Potter, D. (2008). Schools score big when sports teams win.

Foxnews.com. Retrieved April 11, 2011 from

http://www.foxnews.com/wires/2008Mar23/0,4670,FlutieEff ect, 00. html

Ridpath, B. (2011). Perceptions of NCAA Division I athletes on motivations concerning the use of specialized academic support services in the era of the academic progress rate. Journal of Issues in Intercollegiate Athletics, 2010, 3, 253271.

Ridpath, B., Lawrence, H., Yiamouyiannis, A., \& Galles, K. (2008). Why the wrestling coaches are wrong: Judicial and other approaches to the economic reality of Title IX enforcement and preserving the sport of wrestling. Journal of Intercollegiate Sport, 1(2), 255-283.

Sandomir, R. \& Thamel, P. (2010, April 22). TV deal pushes NCAA closer to 68 team tournament. The New York Times.

Retrieved on April 13, 2011 from 
http://www.nytimes.com/2010/04/23/sports/ncaabasketball/2 3ncaa.html? r=1

Sander, L. \& Fuller, A. (2011, July 1). In athletics ambitions compete with costs. Median budget deficit at less elite programs tops 9 million. The Chronicle of Higher Education. 40(LVII). A1; A8-A11.

Siegel, S. (2011, March 28). College basketball coaching changes 2011. CollegeHoops.net. Retrieved April 12, 2011 from http://www.collegehoopsnet.com/college-basketballcoaching-changes-2011-169078

Skousen, C. R. (1988). Goalposts vs. test tubes. Journal of Management Accounting. 60(5). 43-49.

Spence, J. (2005). The NCAA basketball tournament: hard pressed to profit. Retrieved March 1, 2011, from http://www.wm.edu/news/?id=4426

Staples, A. (2011). Who's laughing now? Beebe, Big 12 hit pay dirt with Fox Sports TV deal. SI.com. Retrieved April 10, 2011 From http://sportsillustrated.cnn.com/2011/writers/andy_staples/04 /13/big.12.tv.deal/

Stinson, J. L., \& Howard, D. R. (2007). Athletic success and private giving to athletic and academic programs at NCAA institutions. Journal of Sport Management. 21, 235-264.

Suggs, W. (2003, May 2). Sports as the university's 'front porch'? The public is skeptical. Retrieved on April 11, 2011 from http://chronicle.com/article/Sports-as-the-University-s/11599

TNS Media Intelligence. (2007). TNS Media Intelligence releases March Madness advertising trends report. Retrieved March 1, 2011, from http://www.tns-mi.com/news/03062007.htm

Tublitz, N. (2008). UO basketball arena: Misguided university

Priorities? Retrieved March 31, 2011 from http://www.collegeathleticsclips.com/s/375/index.aspx?sid=3 $75 \&$ gid $=1 \&$ pgid $=15 \&$ cid $=292 \&$ newsid $=1237$

Vedder, R., Villwock, R. \& Denhart, M. (2009, April). The academic athletic trade off: Universities and intercollegiate athletics. A Report from the Center for College Affordability and Productivity. Washington, DC. 
Walker, D. (2007). Naming rights for college stadiums. Milwaukee Journal Sentinel. Retrieved March 8, 2011 from http://blogs.jsonline.com/businessofsports/archive/2007/08/3 1/naming-rights-for-college-stadiums.aspx

Women's Sports Foundation. (2008. Title IX media helper. Retrieved March 6, 2011, from http://www.womenssportsfoundation.org/cgibin/iowa/issues/rights/article.html?record=189

Wolf, B. D. (2007, April 29). The name game. The Columbus Dispatch, p. F1.

Zimbalist, A. (2008). Day of reckoning is coming for colleges, and it won't be pretty. Street \& Smith's SportsBusiness Journal. Retrieved May 19, 2011 from http://www.sportsbusinessjournal.com/index.cfm?fuseaction =article.preview\&articleid=59041 
The Journal of SPORT, 2012, 1, 91-107

(C) Kent State University

\title{
The Fitness and Wellness IQ: Measuring College Student Learning in Campus Recreation Fitness and Wellness Programs
}

\author{
Paul Rohe Milton, \\ Ashland University \\ Lisa M. Roth, \\ Clayton State University \\ Erin C. Porter, \\ Hillsdale College \\ Pepsi Hutton \\ Penn State University
}

\begin{abstract}
Collegiate campus recreation departments are held to increasingly higher levels of accountability, particularly as to whether recreational programs and activities have impact on student learning. This pioneering study found that students who participated in selected fitness and wellness programs offered by a certain four-year, public institution of higher education in the Mid-west scored significantly higher $(\mathrm{t}=3.865, \alpha=.000, \mathrm{sd}=2.68)$ on an exam (the Fitness and Wellness IQ) designed to test their knowledge and understanding of appropriate fitness and wellness practices. Certain demographic categories (gender, age, and residence) produced significant differences in mean scores. These findings have important ramifications for campus recreation departments, divisions of student affairs, and institutions of higher education in general based on the impact on student learning from traditionally non-academic institutional programming.
\end{abstract}


The concepts of fitness and wellness have become increasingly important in the administration of campus recreation programs at universities and colleges across the country and have been made ever more so by the recent interest in and impact of Learning Reconsidered 2 (Keeling, 2006). Fitness and wellness knowledge has gained in interest among university and college campuses, especially campus recreation programs. Most university and college administrators would acknowledge that students learning good fitness and wellness practices, and leaving the institution with such knowledge, is an important contribution that recreational sports makes to a student's well-being, if not their overall education. Organizations such as the American College of Sports Medicine (ACSM), National Intramural Recreational Sports Association (NIRSA), and the American Alliance for Health, Physical Education, Recreation, and Dance (AAHPERD) support and promote the importance of fitness and wellness practices among colleges and universities.

Furthermore, institutions of higher education are expected to be more accountable than ever; not just for financial resources, but also for impact on student learning (Keeling, 2006). The Council for the Advancement of Standards in Higher Education (CAS) released its most recent standards for recreational sports programs with a mission, "to promote the improvement of programs and services to enhance the quality of student learning and development" (Council for the Advancement of Standards in Higher Education, 2008). These standards guide recreational sports programs in learning and assessment outcomes and were inspired by Learning Reconsidered (Keeling, 2004) and Learning Reconsidered 2 (Keeling, 2006). Specific CAS outcomes for recreational sports wellness programs state that wellness programs should "encourage achievement of one's full health potential. These programs should provide an opportunity to work cooperatively with professionals in health services including counselors and physicians, and may be accomplished in concert with others who are similarly oriented" (CAS standards, 2005). Even traditional service-oriented units, such as multicultural student affairs and campus recreation departments are expected to have a positive influence on student learning through 
CAS standards. This is done primarily through the identification and development of learning outcomes and the tools to measure them.

In today's higher education environment, developing learning outcomes has become an important consideration at all institutional levels, including departments of campus recreation. Student Affairs units have generally accepted the concepts put forth in Learning Reconsidered (Keeling, 2004), and more recently Learning Reconsidered 2 (Keeling, 2006). Learning Reconsidered 2 was instrumental in laying the groundwork for the development of assessments that would further reveal and even justify the role of student affairs programming in enhancing student learning. The concepts addressed in Learning Reconsidered 2 provided a foundation for the concepts of student learning outcomes, especially for student affairs oriented departments. NIRSA plays a major role in making sure that the tenets espoused in Learning Reconsidered 2 are promulgated in campus recreation programs across the United States through providing recommendations and supporting research to its member institutions.

\section{Related Literature}

There has been a plethora of research conducted regarding the impact of a campus recreation program on students. These studies typically address retention, socialization, and student development from a student affairs mindset, but do not specifically deal with how a campus recreation program contributes to a student's basic knowledge of fitness and wellness, or contributes more generally to student learning. Henchy (2011) discussed the impact of campus recreation programs on student retention in regard to building a sense of community and student involvement in oncampus activities. It was found that involvement in campus recreation programming contributed to overall student satisfaction with the university (Henchy, 2011). This involvement led to increased student retention rates, yet no discussion on the academic impact of such programs was addressed (Henchy, 2011).

Lindsey, Sessoms, and Willis (2009) also discussed the impact of campus recreation programs on African American student recruitment and retention. The findings in this study were consistent 
with Henchy (2011) in that the availability of campus recreation programs played a significant role in the student's decision to attend the particular university population studied. According to Lindsey et al. (2009) "Forty-seven percent of the students surveyed reported that the availability of recreational sports was important/very important in deciding to continue at college" (p. 29). Moffitt (2010) added to the literature regarding the relationship between student retention, academic success, and campus recreation programming. The results of this study indicated that campus recreation program participation had a statistically significant effect on student academics (Moffitt, 2010). These findings support the contentions of both Henchy (2011) and Lindsey et al. (2009), however, little research has been conducted in relationship to the overall impact of campus recreation programs on the basic fitness and wellness knowledge of students.

In addition to the lack of student learning research in campus recreation, there has been little research on specific learning outcomes established by campus recreation programs within divisions of student affairs. The current research provides extensive discussion on the process of developing learning outcomes for campus recreation departments, but little research has been done on the potential gains in fitness and wellness knowledge among participants in campus recreation programs. Present learning outcome research for campus recreation programs has placed a general focus on the student's ability to effectively contribute to society upon graduation. For example, Cooper, Flood, and Gardner (2009), outlined the following learning outcomes for a campus recreation program, time management, social competence, achievement motivation, intellectual flexibility, task leadership, emotional control, active initiative, self-confidence which all stem from the Life Effectiveness Questionnaire-version H (LEQ-vH). There is little consideration given to student academic learning within the article, rather, a general focus placed on development of basic life-skills as described in Cooper et al.'s (2009) learning outcomes.

Fortman and Haines (2011) developed the Measuring Outcomes from Recsports Experiences (MORE) based on Keeling's 
(2006) Learning Reconsidered 2 to include learning outcomes such as effective communication, enhanced self-esteem, realistic selfappraisal, leadership development, life skills, healthy behaviors, and satisfying and productive lifestyle. These learning outcomes describe the overall development of student participation in campus recreation programs, but do not specifically address the impact of these programs on the fitness and wellness knowledge of students participating in these programs.

The amount of fitness and wellness knowledge that a student could obtain from participation in a campus recreation program potentially-contributes to overall socialization. However, there are a number of other benefits to the student that can be derived from this knowledge. These benefits include the ability to take control of one's life, manage stress, experience physical fitness gains, and contribute to the economic status of the nation by lowering health care costs and paying fitness and wellness professionals for these services (Hoeger \& Hoeger, 2011). Student learning through institutionally provided campus recreation fitness and wellness programs has not been researched though there are a number of benefits to the student by learning about fitness and wellness through participation in these programs.

As Keeling (2006) indicated in Learning Reconsidered 2, "Student affairs educators... want to demonstrate that there must be an assessment of quality and value---in terms of student learning---in every program and activity" (p. 2) . It is important to take research conducted in a program most often housed in student affairs, campus recreation, and conduct research that tests whether learning has occurred during in any of the activities offered by such a program. Therefore, the purpose of this investigation was twofold: 1) To develop and deploy pedagogy to student participants in institutional provided fitness and wellness programs, and 2) to compare their fitness and wellness knowledge to that of students who did not participate in institutional provided fitness and wellness programs. 


\section{Methods}

\section{Instrument Development}

Following an extensive review of previous research and other available fitness and wellness knowledge tests, it was found that there were very few instruments available from scholarly sources or nationally recognized fitness bodies designed to measure the comprehensive fitness and wellness knowledge of a college fitness and wellness participant. This review led to the development of a specialized Fitness and Wellness IQ test that was used to determine the knowledge of students following their participation in certain campus recreation fitness and wellness programs. The Fitness and Wellness IQ test was a series of 25 multiple-choice questions. Each question contained four possible choices, with only one answer serving as the best possible choice. Eight demographic questions were included and typified those included in survey research in campus recreation: gender, ethnicity, age, grade point average (GPA), class standing, college or independent school, intercollegiate athlete, and residence. In developing the Fitness and Wellness IQ test, consideration was given to guidelines and parameters set by the Diagnostic Statistical Manual of Mental Disorders (DSM-IV), the American College of Sports Medicine, Center for Disease Control (CDC), the Aerobics Fitness Association of America (AFAA), and the American Dietetics Association. Questions were developed from these sources. The authors secured a Human Subjects Review Form from the office of Institutional Research at the institution studied. The research proposal received approval from the Institutional Research Board.

\section{Design}

The research design was experimental. Participants who enrolled in the fitness and wellness programs underwent an "intervention" that was threefold: 1) the fitness wellness instructors presented salient fitness and wellness information during each of their class meetings, 2) the participants received the same information, as a reinforcement of the information conveyed by the instructors, through weekly e-mails, and 3) the same information 
was posted in selected areas of the recreation center at the institution that participated in the study. These areas were identified as those in which it was likely that the participants would notice it, such as the fitness floor and the fitness and wellness suite.

Following these interventions, and at the conclusion of the particular fitness and wellness programs, the Fitness and Wellness IQ was administered first to participants of fitness and wellness programs provided by a department of recreational sports at the institution which participated in the study. The exam was similar to one a student might be required to take in a credit class, the questions were multiple choice. Although reliability coefficients were somewhat low $(r=0.40)$, the test was piloted with a group of students enrolled in Fitness or Wellness classes, and the questions were reworked. The actual trial produced only slightly higher coefficients $(r=0.45)$.

\section{Participants}

The study was conducted at a four-year, public institution of higher education in the mid-west with a total enrollment of approximately 24,000 students. A total of 243 participants in fitness and wellness programs agreed to take the Fitness and Wellness IQ test. These participants self-selected from a total of 550 students who were enrolled in the fitness and wellness programs, meaning that 44.2 percent of those who were enrolled agreed to take the Fitness and Wellness IQ test. The Fitness and Wellness IQ test was also administered to a randomly selected group of students who had never participated in any fitness or wellness programs offered by the recreational sports department at any time as a student at the institution. Although 110 students who fit this category took the exam, the SPSS statistical analysis employed automatically adjusted for an unequal sample size when an independent samples t-test was conducted. It was also determined that of those students who listed their gender, the total number of females who took the test was 295 $(84.8 \%)$, and the total number of males was 53 (15.2\%). The number of traditionally-aged students enrolled in the fitness and wellness programs who took the test was $163(73.8 \%)$, while the number of traditionally-aged students who took the test but were never enrolled 
in the programs at the institution was $58(16.2 \%)$. The number of non-traditionally aged students enrolled in the fitness and wellness programs who took the test was $75(68.2 \%)$, while the number of non-traditionally students who took the test but were never enrolled in the programs at the institution was 35 (31.8\%). Finally, the number of commuter students enrolled in the fitness and wellness programs who took the test was $93(54.1 \%)$, while the number of commuter students who took the test but were never enrolled in the programs at the institution was $79(45.9 \%)$.

\section{Data Analysis}

The researchers conducted an independent samples t-test using the SPSS version 15.0.1 statistical package. All data were tested at $\alpha=.05$, the level commonly used in inferential research in the field of recreational sports. Means and standard deviations were employed to compare the test scores of students who participated in the fitness and wellness programs against the test scores of students who had never participated in the fitness and wellness programs offered by the institution's campus recreation department.

\section{Results}

Overall, a significant difference was found between the mean scores of the two groups $(\mathrm{t}=3.865, \alpha=.000, \mathrm{sd}=2.68)$. The mean score on the exam of the students who participated in the offered fitness and wellness activities was $14.41(\mathrm{sd}=2.68)$. The group that had never enrolled in fitness and wellness programs produced a mean score of 13.25 ( $\mathrm{sd}=2.58)$, (Table 1$)$ the overall difference in mean score between the group who enrolled in the fitness and wellness programs and those who had never enrolled was 1.16. Although this research did not factor out prior participation in fitness and wellness programs, it was safe to report about those who participated. Those students who participated in certain fitness and wellness programs at the institution studied in this investigation had a better understanding of appropriate fitness and wellness constructs than those who did not participate. Students who were enrolled in the fitness and wellness programs had a significantly higher understanding and knowledge of good fitness and wellness concepts 
and practices. The research also considered other comparisons based on selected demographics. The following sections discuss statistically significant differences found based on gender, age, and residence.

\section{Gender}

The study found that women who participated in the fitness and wellness programs in which the intervention occurred scored significantly higher than women who did not participate in the fitness and wellness programs $(\mathrm{t}=3.09, \alpha=.002)$. The mean difference between the two groups was $1.10(\mathrm{~N}=295)$, a mean of $14.47(\mathrm{n}=219, \mathrm{sd}=2.69)$ for those who were enrolled in the fitness and wellness programs versus $13.37(n=76, s d=2.78)$ for those who had never enrolled. No differences were found between males who were enrolled in the programs and those who had never enrolled (Table 1).

\section{Age}

In regard to age, the study found that both male and female traditionally-aged students, defined as those aged 17 to 24 years, who were enrolled in the fitness and wellness programs scored significantly higher than the traditionally-aged students who had never enrolled in the programs $(\mathrm{t}=2.30, \alpha=.023)$. The mean difference in scores between these two groups was $0.88(\mathrm{~N}=221)$, a mean of $14.43(n=163, s d=2.48)$ for those who were enrolled in the fitness and wellness programs versus $13.55(n=58, \mathrm{sd}=2.56)$ for those who had never enrolled.

Non-traditionally aged male and female students who were enrolled in the fitness and wellness programs, those 25 years of age and older, were also found to score significantly higher than those who had never enrolled in the programs $(\mathrm{t}=2.03, \alpha=.044)$. The mean difference in scores between these two groups was $1.21(\mathrm{~N}=$ $110)$, a mean of $14.52(n=75, s d=3.06)$ for those who were enrolled in the fitness and wellness programs versus a mean of $13.31(n=35$, $\mathrm{sd}=2.51$ ) for those who never enrolled (Table 1). 


\section{Residence}

Finally, the study found that commuter students who were enrolled in the fitness and wellness programs scored significantly higher than the commuter students who had never enrolled in the programs $(t=3.58, \alpha=.000)$. The mean difference in scores between the two groups was the highest observed in any of the tests, $1.31(\mathrm{~N}=172)$, with a mean of $14.94(\mathrm{n}=93, \mathrm{sd}=2.45)$ for those who were enrolled in the fitness and wellness programs versus a mean of $13.58(n=79, \mathrm{sd}=2.49)$ for those who had never enrolled. No difference was found between residence hall students enrolled in the programs and residence hall students who had never enrolled (Table $1)$.

Table 1 Independent Samples T-Test Results

\begin{tabular}{|c|c|c|c|c|c|c|c|}
\hline Variable & \multicolumn{2}{|l|}{$\mathrm{N}$} & Mean & $\begin{array}{c}\text { Mean } \\
\text { Diff. }\end{array}$ & $\begin{array}{l}\text { Std } \\
\text { Dev }\end{array}$ & $\mathrm{t}$ & $p$ \\
\hline Overall & $\begin{array}{l}\text { Participant } \\
\text { Non-Participan }\end{array}$ & $\begin{array}{l}242 \\
110\end{array}$ & $\begin{array}{l}14.41 \\
13.25\end{array}$ & 1.16 & $\begin{array}{l}2.68 \\
2.58\end{array}$ & 3.87 & .000 \\
\hline Gender $(F)$ & $\begin{array}{l}\text { Participant } \\
\text { Non-Participan }\end{array}$ & $\begin{array}{r}219 \\
76\end{array}$ & $\begin{array}{l}14.47 \\
13.37\end{array}$ & 1.10 & $\begin{array}{l}2.69 \\
2.78\end{array}$ & 3.09 & .002 \\
\hline $\begin{array}{c}\text { Traditional } \\
\text { Age } \\
(17-24)\end{array}$ & $\begin{array}{l}\text { Participant } \\
\text { Non-Participant }\end{array}$ & $\begin{array}{r}163 \\
58\end{array}$ & $\begin{array}{l}14.43 \\
13.55\end{array}$ & 0.88 & $\begin{array}{l}2.48 \\
2.56\end{array}$ & 2.30 & .023 \\
\hline $\begin{array}{c}\text { Non- } \\
\text { Traditional } \\
\text { Age } \\
(25+)\end{array}$ & $\begin{array}{l}\text { Participant } \\
\text { Non-Participant }\end{array}$ & $\begin{array}{l}75 \\
35\end{array}$ & $\begin{array}{l}14.52 \\
13.31\end{array}$ & 1.21 & $\begin{array}{l}3.06 \\
2.51\end{array}$ & 2.03 & .044 \\
\hline $\begin{array}{l}\text { Residence, } \\
\text { Commuter }\end{array}$ & $\begin{array}{l}\text { Participant } \\
\text { Non-Participant }\end{array}$ & $\begin{array}{l}93 \\
79\end{array}$ & $\begin{array}{l}14.94 \\
13.56\end{array}$ & 1.36 & $\begin{array}{l}2.45 \\
2.49\end{array}$ & 3.58 & .000 \\
\hline
\end{tabular}

\section{Discussion}

\section{Overall Participation}

The results of this research study provided pioneering information on the potential impact of fitness and wellness programs in student learning. A primary strength of the Fitness and Wellness IQ test was that there were no scholarly tests available of its kind. 
The test provided a measure of student knowledge gained from participation in campus recreation fitness and wellness programs. These results indicated that students who participated in the selected fitness and wellness programs at the institution under study scored significantly higher on the Fitness and Wellness IQ test than students who had never participated in the programs. This finding has important implications for campus recreation. The first is that, at least at this institution, the fitness and wellness programs had a beneficial impact on the fitness and wellness knowledge of students who participated in the programs.

Related research conducted by Vansickle, Hancher-Rauch, and Hicks (2010) reported that fitness programs were an effective way of implementing fitness pedagogy and creating an interaction between faculty and staff members. In this study, Vansickle et al. (2010) created a fitness program model that increased the knowledge about fitness and wellness of the faculty and staff on the Indiana University campus. Certain campus recreation fitness and wellness programs had a positive impact on student learning. It remains to be seen whether the same could be true of other campus recreation programs, or other student affairs programs for that matter. However, the fact that students who were in the programs scored higher on the Fitness and Wellness IQ increases the value and importance of campus recreation fitness and wellness programs, and appears to enhance the need for such programs on college campuses, or certainly at this particular campus.

Furthermore, the results of this study support the need for campus recreation programs on college campuses. Through the statistically significant findings, there is empirical evidence that the student population at this institution should be provided with programs that house student learning in the areas of fitness and wellness and that campus recreation can assist in student learning in addition to its academic and student affairs counterparts. This study can also help campus recreation programs build an educationally based curriculum. Campus recreation can now make fitness and wellness a priority to integrate into the lives of students and create an education framework for fitness and wellness learning outcomes. The research serves as a stepping stone for campus recreation to 
continue to build fitness and wellness programs that will support its purpose and enhances the lives of students on a college or university campus similar to what was proposed in the Vansickle et al. (2010) study on Indiana University's faculty and staff.

\section{Gender}

Gender results indicate that female students who participated in fitness and wellness programs scored significantly higher than those females who did not participate in these programs.

Conversely, it was determined that there were no differences among the male students regardless of participation in the fitness and wellness programs. There are several positive implications for campus recreation that stem from the results of this demographic. First, the need for fitness and wellness programs that continue to target female students was reinforced. Based on this finding, campus recreation can and should, continue to design fitness and wellness programs specifically for females in order to educate them on the importance of lifetime fitness and wellness. In fact, it could be argued, based on the findings, that additional institutional and departmental funding be devoted to the enhancement of such programs for female students. Fitness and wellness instruction or activity programs have long been recognized as one of the most utilized programs by female students, and the results of this study indicate that they are learning valuable information that complements the benefits of the physical activity. The second implication of these findings is that campus recreation programs are now aware of the statistical indifference in fitness and wellness knowledge among males. This could mean that the male population is more educated in the area of fitness and wellness based on lifestyle and socialization factors involving certain aspects of fitness and wellness including weightlifting, sport participation, and the like.

\section{Age}

Findings in the age demographic indicated that fitness and wellness programs had significant effects on the knowledge base of participants regardless of age and that these programs indeed had a 
positive influence on student learning. The age differentiation, traditionally aged students vs. non-traditionally aged students is a frequently studied demographic in campus recreation participation research, most of it reporting that traditionally aged students were more likely to enter recreational facilities (Milton \& Patton, 2011), were more likely to participate in organized campus recreational sports (Barcelona \& Ross, 2002), and more likely to participate in campus recreation in general (Frauman, 2005) than were their nontraditionally aged counterparts. The results of this study do not contradict the aforementioned disparity in actual participation numbers between the two age groups; rather it validates the existence of such programs for both groups. In fact, it could be argued that fitness and wellness programs be expanded particularly for non-traditionally aged students because of the long held, and well documented belief that older students are often disenfranchised from participation in most non-academic programs in America's colleges and universities.

\section{Residence}

The results of the residential factor indicated that commuter students who were involved in fitness and wellness programs scored higher than those students who commuted and did not participate in these programs. There was no significant difference between those students who stayed in the residence halls. This may be because students who live on campus are constantly exposed to fitness and wellness flyers, friends on sports teams at the institution that may have to follow certain guidelines that deal with fitness and wellness, or who already have constant access to a weight room or cardio machines. Participants who are surrounded by these types of information may become unresponsive to fitness and wellness information compared to those who commute. Commuters may not be exposed to the same amount of subliminal messages as resident students which, in part, would explain the lack of fitness and wellness knowledge, and the potential for a more dramatic increase in such knowledge. Bahrami (2007), of the UCL Institute of Cognitive Neuroscience conducted a study testing "whether an 
image you are not aware of has an impact on brain activity" (p. 1). Bahrami (2007) stated,

Your brain does log things that you aren't even aware of and can't ever become aware of. We show that there is a brain response in the primary visual cortex to subliminal images that attract our attention -- without us having the impression of having seen anything. (p. 1)

These findings suggest that those participants in the current study who live on campus are constantly processing fitness and wellness message in the campus recreational facility more than those who are commuters. An example would be a flyer posted in the campus recreational facility inviting students to an event that has a small phrase or symbol hinting towards fitness and wellness without them being aware of it. Based on Bahrami's (2007) findings, subliminal messages can have a huge impact on how much information a participant may come in contact with, whether participants are aware of it or not. The normalcy of fitness and wellness information could affect how the residence hall participants perceive the fitness and well programs.

\section{Limitations}

The findings of this study are relevant to like-sized four-year public institutions of higher education with a Carnegie Research Extensive designation. However, caution must be observed in applying the results in such settings. Each institution of higher education is different and the effectiveness of the Fitness and Wellness IQ test could also vary. Careful consideration must be given to the demographics of the student population in comparison institutions to ensure the effectiveness of the test among all institutions of higher education and campus recreation programs.

Another limitation is that no pre-test was given the students who participated in the programs to serve as a control for prior knowledge and understanding of wellness and fitness practices. The results of the tests still suggest that students participating in fitness 
and wellness programs significantly increased their knowledge of fitness and wellness through participation in these programs as compared to their counterparts who did not utilize the programs. The study did not collect data on the daily fitness and wellness behaviors of the participants. Information on the daily fitness and wellness behaviors such as eating habits, dieting, activity levels, and recreational sports participation could have added participant bias.

The coefficients of reliability were low enough to be of some concern about the usefulness of the results. Statistically significant differences in the test score means suggest that learning did occur among those who enrolled in the programs, at least on the questions asked on the Fitness and Wellness IQ.

\section{Future Research}

There are a number of opportunities for future research regarding student learning within fitness and wellness programs. Additional participant demographics could be collected prior to the study in order to assess whether sport participation or other factors played a role in the fitness and wellness knowledge of the tested students. Other demographics might include sport participation prior to this study and a structured environment with diet. This could assist the researchers in concluding whether fitness and wellness program participation was the contributing factor in regard to the Fitness and Wellness IQ scores. A pre-test could also be given to assess the previous fitness and wellness knowledge of the students tested. This would provide the researchers with more information on the change in knowledge before and after participating in fitness and wellness programs. Other versions of this test should include a pre and post-test in order to generate the most accurate data regarding the effectiveness of the Fitness and Wellness IQ test. Another opportunity for future research is to compare four-year institutions to two-year institutions. Comparing different types of institutions would allow for more accurate findings for all campus recreation programs and institutions as well as a larger population to sample. 


\section{References}

Bahrami, (2007). Subliminal Advertising Leaves Its Mark On The Brain. Science Dailey. Retrieved January 15, 2012, from http://www.sciencedailey.com/releases/2007/03/0703081219 38.htm

Barcelona, R., \& Ross, C. (2002). Participation patterns in campus recreational sports: An examination of quality of student effort from 1983 to 1998. NIRSA Journal, 26(1): 41 - 53

Cooper, N., Flood, J., Gardner, E. (2009). Establishing a learning outcomes plan for campus recreation. Recreational Sports Journal, 33(1), 12-24.

Council for the Advancement of Standards in Higher Education. (2008). Mission. Retrieved from

www.cas.edu/index.php/about/mission/

Fortman, T.L., \& Haines, D. J. (2011). Measuring outcomes from recsports experiences (MORE) instrument validation: A valuable tool to assess college student learning. Recreational Sports Journal, 35(1), 12-23.

Frauman, E. (2005). Differences between participants and nonparticipants of campus recreation offerings across demographic variables and perceptions of the college experience. Recreational Sports Journal, 29(2): 156-165.

Henchy, A. (2011). The influence of campus recreation beyond the gym. Recreational Sports Journal, 35(2), 174-181.

Hoeger, W. W. K. \& Hoeger, S. A. (2011). Lifetime physical fitness \& wellness: A personalized program $\left(11^{\text {th }}\right.$ Ed.). Belmont, CA: Wadsworth.

Keeling, R., Ed. (2004). Learning Reconsidered. ACPA, ACUHO-1, ACUI, NACA, NACADA, NASPA, NIRSA publishers.

Keeling, R., Ed. (2006). Learning Reconsidered 2: A Practical Guide to Implementing a Campus-wide Focus on the Student Experience. ACPA, ACUHO-1, ACUI, NACA, NACADA, NASPA, NIRSA publishers.

Lindsey, R., Sessoms, E., \& Willis, G. (2009). Impact of campus recreational sports facilities and programs on recruitment and 
retention among African American students: A pilot study. Recreational Sports Journal, 33(1), 25-34.

Milton, P., \& Patton, B. J. (2011). Who enters campus recreation facilities: A demographic analysis. International Journal of Sport Management, Recreation and Tourism, Electronic journal August 2011, Volume 7, Article a.

Moffitt, J. (2010). Recreating retention. Recreational Sports Journal, 34(1), 24-33.

Vansickle, J., Hancher-Rauch, H., \& Hicks, L. (2010). Designing a university-wide fitness program to promote campus health and department image. Journal of Physical Education, Recreation, and Dance, 81(1), 27-32. 
The Journal of SPORT, 2012, 1, 108-139

(C) Kent State University

\title{
Division I Football Bowl Subdivision (FBS) Student-athlete perceptions on their NCAA postseason arrangement: A forced- choice certainty method survey approach
}

\author{
Chad Seifried \\ Louisiana State University \\ Brian A. Turner \\ The Ohio State University
}

\begin{abstract}
The Division I Football Bowl Subdivision (FBS) within the National Collegiate Athletic Association (NCAA) continues to grow in popularity. However, the current system of selecting teams to play for the national championship remains a much-debated and controversial issue. The thoughts of university presidents, athletic directors, football coaches, and even United States congressmen regarding the current Bowl Championship Series (BCS) system are numerous and welldocumented. However, the opinion of the actual participating student-athlete is generally absent within the popular and scholarly discussion. The purpose of this study was to investigate the views of active Division I FBS student-athletes regarding the BCS and post-season play through a forced-choice certainty survey. Specifically, a forced-choice certainty method survey approach was used to explore both the directional and certainty judgment of 79 football student-athletes in order to compare points of interest (i.e., BCS v. Playoff Alternatives). Statistical results from the study showed participants questioned the fundamental fairness of the current BCS system and generally would prefer a playoff system because the current BCS system does not produce a "true" champion in their opinion. Finally, this study importantly offers a serious attempt to begin collecting information on this topic from an understudied group important in college football.
\end{abstract}


The changing nature of the selection process and criteria of the Bowl Championship Series (BCS) has produced a variety of heated debates concerning the merits and fairness of the Division I Football Bowl Subdivision (FBS) postseason arrangement. As an example, Seifried and Smith's (2011) investigation of U.S. Congressional hearings conducted between 2003 and 2009, Seifried's $(2011,2012)$ review of media literature pre-BCS (i.e., 1960-1999), and Southall, Southall, and Dwyer's (2009) examination of BCS broadcasts all discovered several consistent arguments and contrasting claims involving important stakeholders (e.g., athletic directors, conference commissioners, university presidents/chancellors, bowl representatives, and head coaches) associated with the operation and management of college football. Similarly, Oriard (2009), Sandbrook (2004), and Smith (2001) also criticized the operation of the Division I FBS postseason. Collectively, these works highlighted disagreements regarding the: a) logistical possibility of alternative postseason formats and their impact on student-athlete welfare; b) the financial discrepancy between BCS and non-BCS institutions under the BCS system versus alternative postseason arrangements; and c) the alleged bias and barriers the BCS selection process employed related to institutional missions.

Non-BCS schools (e.g., Mid-American Conference, Sun Belt, Western Athletic Conference, Mountain West Conference, and Conference-USA, along with Army and Navy) and their representatives (i.e., commissioners) expressed great dissatisfaction with their lack of a realistic opportunity to compete for a national title and the barriers they faced obtaining entry or invitation to one of the five BCS bowl games (Seifried \& Smith, 2011; Seifried, 2011). BCS bowl games include the Rose Bowl, Sugar Bowl, Orange Bowl, Fiesta Bowl, and the BCS National Championship Game. Non-BCS schools also criticized the payouts they received for BCS contests because they were significantly less than that provided to their BCScharter member peers (e.g., Atlantic Coast Conference, Big 12, Southeastern Conference, Big Ten, Pac-10, Big East, and Notre Dame) for participation in the same contest. As an example, Texas 
Christian University (Mountain West) and Boise State University (Western Athletic) received bids to participate in 2010 Fiesta Bowl yet they were only paid $\$ 9.8$ million and $\$ 7.8$ million respectively for participation. BCS-charter conferences each secured over $\$ 17.7$ million for their participation in a single BCS game (National Collegiate Athletic Association, 2010).

BCS representatives generally sympathized, entertained, and presumed the bowl tradition would be significantly injured or cease to exist if an alternative postseason format was implemented. They also noted a lack of bowl games or reduced interest in them would negatively impact host communities and the various charitable causes they serve. BCS supporters further challenged the notion that an alternative postseason arrangement would be better for the academic welfare of the student-athletes and promoted the possible logistical difficulties which might face members of their respective fan nations to attend contests under alternative postseason formats as entirely legitimate (Oriard, 2009; Seifried, 2011, 2012; Seifried \& Smith, 2011).

To further illustrate the nature of this debate, the subjective ratings (i.e., Coaches and Harris Poll) and mathematical formulas (i.e., computer polls) utilized by the BCS also inflamed the various discussions (Buchman \& Kadane, 2008; Seifried, 2011, 2012; Seifried \& Smith, 2011; Stern, 2004). As the main sources of material to determine automatic and at-large selections available for any one of the five BCS bowl games, the BCS selection process provided only the University of Oregon (12-0) and Auburn University (13-0) the opportunity to play for the 2010 BCS national title, while another undefeated team (Texas Christian University 120) watched from afar. Previous years produced similar protests from enraged fans of both BCS and non-BCS schools not selected for the national title game and other BCS games. For instance, just one year before, the University of Alabama (13-0) met the University of Texas at Austin (13-0) for the 2009 BCS national title despite the fact several others (Boise State, 12-0, Texas Christian 12-0, and Cincinnati 12-0) produced similar undefeated records and deserved consideration. In 2008, both Boise State (12-0) and Texas Tech (11 
1) also completed outstanding regular seasons but due to BCS rules and a perceived lack of marquee appeal both were left out of the BCS. Again, this episode seems to repeat annually.

Almost the entire debate concerning the Division I FBS postseason arrangement has emerged from administrators and coaches who compared the prospective benefits and negative consequences offered by various postseason formats against those provided by the unique bowl game experience. A collection of student-athlete opinions and their preferences is woefully absent and underdeveloped from previous discussions and studies (Seifried, 2011, 2012; Seifried \& Smith, 2011). It should be noted that the National Collegiate Athletic Association (NCAA) did establish some committees to view the idea of a national tournament from the perspective of student-athletes during the past couple decades. For instance, in 1993 a group to study the feasibility of a Division I-A [FBS] Football Championship was established which surveyed ten student-athletes representing Division I-A [FBS] institutions (“Committee opposes football," 1993).

Another attempt in March of 1994 surveyed 12 different student-athletes who also indicated they believed a national championship should be determined on the field. Then Executive Director of the NCAA Cedric W. Dempsey argued "In general, they [i.e., student-athletes] were positive about a national championship concept... to find out who's the best" ("Student-athletes voice," 1994, p. 1). In 2010, ESPN surveyed another 135 student-athletes from Division I FBS but that effort was hardly academic and asked just three basic questions which provided few comprehendible answers ("College football playoff confidential," 2010). In the end, these investigations failed to provide an adequate supply of player opinions and structured/valid surveys to confidently report the collective view of the playoff topic from the student-athlete perspective.

Football student-athletes are an important group to survey due to their direct involvement in the core production of the BCS and any potential alternative postseason formats. They are also, as noted above, offered up as a group to protect academically and 
physically from winning-centered coaches, administrators, donors, and alumni looking to possibly expose their talents for their own personal gain (Oriard, 2009; Seifried, 2012; Seifried \& Smith, 2011). Recent dialogue created within the BCS showed a playoff may be in their future plans, with the most notable proposal supporting a fourteam tournament ("BCS takes big step," 2012).

The purpose of this paper serves to formally report valuable exploratory information from an important stakeholder group (i.e., FBS student-athletes) about the current Division I FBS postseason arrangement and possible alternatives (i.e., playoff). Specifically, active student-athletes were surveyed to capture their level of agreement with the BCS bowl system and the various potential alternative postseason formats from a logistical, financial, physical, and academic perspective. To begin the process of identifying the potential thoughts of all Division I FBS football student-athletes, the researchers chose a convenience sampling method and utilized a forced-choice certainty survey device to obtain important data which could be used to help begin the resolution of certain points regarding the BCS and playoff dilemma. As recent discussions show, the playoff may be in the near future of the BCS

\section{Additional Literature Review}

In Bowled over: Big-time college football from the sixties to the BCS era, Michael Oriard (2009) wrote about his perspective as a former student-athlete at Notre Dame and the various reform movements supported within the NCAAs since the 1960s. Those reform items included discussions about freshman eligibility standards, institution admission baselines, separation of the NCAA into separate divisions (i.e., I FBS, I FCS, II, and III), and the implementation of the one-year renewable scholarship. Oriard's book traced those watershed moments and their impact on the growth of Division I FBS football as a commercial product while simultaneously recognizing student-athletes as the core commodity used to generate revenue for institutions. Oriard fascinatingly argued that Division I FBS bowls games since the 1960s were also a product of this commercial environment and ultimately served to undermine 
institutional academic missions through the support of entitlement and exploitation initiatives. In the end, Oriard suggested more work needs to be protect student-athletes and that their feedback needed to be included in the decision-making process regarding future change initiatives.

Ronald Smith (2001) in Play-by-play: Radio, television and big-time college sport famously reviewed college football media coverage and specifically the interaction between the NCAA and multiple television and radio broadcasting organizations. From this review, Smith argued a separation between Division I institutions of higher education within the NCAA (i.e., BCS and non-BCS institutions) resulted from television revenue. Furthermore, television dollars prompted the various reform movements mentioned above by Oriard and the exploration of bowl games and alternative postseason formats as comparable commercial products. Smith also focused much of his work on the perspectives of NCAA administrators and university leaders (e.g., chancellors and presidents) through their efforts to review the playoff idea but little comment was generated from the student-athlete perspective; they were only recognized as a group to protect within Smith's work.

Seifried and Smith's (2011) content analysis of U.S.

Congressional hearings from 2003 to 2009 reviewed the perspectives of Congress and the Division I FBS administrators regarding the $\mathrm{BCS}$ and the prospective legitimacy of various postseason tournament formats. By focusing on the academic and physical welfare of student-athletes, logistical difficulties of various playoff scenarios, and the speculative damage to bowl communities, BCS administrators were positioned against the playoff idea. Non-BCS administrators differed from these thoughts by suggesting there were possible antitrust violations associated with the current BCS arrangement. An increasing financial gap was also proposed as occurring between FBS institutions along with recognition that the BCS selection process was fundamentally unfair and against the mission of the NCAA. Finally, non-BCS administrators argued the growth of technology and sport infrastructure would adequately serve to reduce any logistical or academic concerns regarding the 
management of the playoff. Again, this document supported a new initiative to compare the competitive and anti-competitive aspects of each position. Furthermore, it highlighted the need to gather the opinion of the student-athlete because the voice of only one former student-athlete (i.e., Steve Young) was heard.

Other works by Seifried $(2011,2012)$ reviewed national media publications (e.g., The New York Times, Boston Globe, Washington Post, etc.) and the NCAA News to communicate important information to justify the purpose and significance of this work. Specifically, Seifried showed the public record of 260 articles historically suggested athletic directors, school presidents, and coaches regularly favored the implementation of a playoff since the 1960s but they regularly disagreed about which arrangement would be best. The range of preferences offered by those groups varied from the small (i.e., four-team) to the very large (i.e., 32) with the four, eight, and sixteen team tournament emerging as the most popular. Student-athletes were noticeably missing as only seven articles recorded their opinions from 1960 to 1998 (Seifried, 2011, 2012).

Finally, John Sandbrook's (2004) Division I-A postseason football history and status, produced for the Knight Commission, provided an excellent historical review of the growth of bowl games while simultaneously providing important data to support those who favored a playoff. For example, Sandbrook promoted the bowl games and their host communities as creating a partnership with college institutions through focusing on the guaranteed payouts provided by those events. Next, Sandbrook presented information related to administrator perspectives on denying the playoff over the years such as that offered above. A variety of financial, television, sponsorship, scheduling, and academic data was used to support the traditional pro-bowl tradition perspective. However, new ideas which focused on the growth of technology and support services offered by academic institutions were also included to help proplayoff supporters. This ultimately prompted Sandbrook to suggest that there is a need to review the potential of a playoff from the core stakeholder (i.e., student-athlete and coaches) perspective in order to 
manage future challenges regarding the NCAA Division I FBS postseason arrangement.

\section{Method}

Koriat, Nussinson, Bless, and Shaked (2008) noted researchers should expect controversial questions which prompt different comparative considerations to demonstrate the most diverse results with regard to certainty. Moreover, if individuals express their opinion truthfully, it should be expected that traditional likertbased rating systems may not accurately summarize collective opinions of a greater group (Bargagliotti \& Li, 2009). Smyth, Smyth, Dillman, Christian, \& Stern (2006) and Sudman, Bradburn, \& Schwarz (1996) suggested opinion-based questions, such as those based on this topic, required more consideration by respondents before they make a decision or judgment. McCarty and Shrum (2000) discovered when values "are not contrasted and psychological anchors are not encouraged... respondents show less discrimination among values" (p. 294-295).

Several other scholars similarly identified a lack of forced differentiation through the opportunity to use personal anchor points of information diminishes the usefulness of some instruments to study important research questions (Greenleaf, Bickart, \&Yorkston, 1999; Rossiter, 2002; Sharma \& Weathers, 2003; Strizhakova, Coulter, \& Price, 2008; Weijters, Cabooter, \& Schillewaert, 2010). McCarty and Shrum (2000) and Bargagliotti and Li (2009) suggested the measurement of ratings scales thus could be improved and that researchers should search to achieve this task. Smyth, et al. (2006) and Dillman, Smyth, Christian, \& Stern (2003) offered forced-choice method formats, such as the one used in this study, as one preferred option. Specifically, Warren, Klonglan, \& Sabri (1969) and Smyth et al. (2006) argued for the forced-choice methods because it requires respondents to consider questions individually through the options provided; thus, the forced-choice certainty method encourages greater cognitive attention and discourages satisficing. Studying the confidence or certainty in people's beliefs through their personal anchor points is also important because it also 
shows the likelihood of whether or not beliefs will be converted into behavior (Gill, Swann, \& Silvera, 1998; Goldsmith \& Koriat, 2008; Hall, Ariss, \& Todorov, 2007). Surveying Division I FBS studentathletes is one valuable activity because they are part of the core product (i.e., postseason football contests) and they can provide great insight about barriers to an alternative postseason format centered on their academic and physical well-being and the possible logistical concerns regarding participation.

To complete this study, student-athletes from a chartermember BCS conference or program (e.g., Big Ten, SEC, ACC, Big East, Big 12, or Pac-10) were selected and surveyed to capture their level of agreement along with the strength of their conviction on the fairness, commercialization, academic/physical welfare, and format preference of the BCS and other postseason formats. Participation in this survey was promoted to the Division I FBS student-athletes as a desire to learn more about the issue from their perspective to help the decision-makers of college football regarding this topic of public debate. The future of the playoff alternative is best served if the perspective of the student-athlete is taken into consideration. Again, as noted above, little to no formal work or public record exists regarding the collective thoughts of this special group.

The investigators provided the survey instrument along with a cover letter explaining the purpose of the research to football student-athletes at a large Division I FBS program following full approval from the institution's human subjects review board during their annual spring football team meeting. The final instrument contained statements to collect insight about their expectations, motivations, and satisfaction regarding the current BCS arrangement and/or potential alternative postseason formats. Of the original 85 student-athletes attending the meeting, the researchers were able to successfully recruit 79 to complete the whole survey. This number represents a $92.9 \%$ response rate and was considered satisfactory for the exploratory nature of this study. Only the fifth year seniors participating in this survey played in a bowl game that was not one of the five BCS contests. All other survey respondents played only in $\mathrm{BCS}$ contests. The number of BCS bowl game opportunities enjoyed 
by these individuals hypothetically presented this group as possibly the most favorable toward the current BCS and bowl postseason arrangement. Final analyses were also conducted to determine if there were differences in opinions based on academic rank and racial background.

A researcher-designed instrument was employed in data collection and based off of previous work initially designed by Cieslak (2009) during his review of Division I FBS coaches opinions. The modified player-focused instrument included 33 items and was reviewed for content validity by two experts noted for their interest in Division I FBS postseason activities. Each statement was carefully edited in an attempt to assure for correct meaning. The number of response categories chosen for the level of certainty scale included five because it was identified as one of the most popular formats (Weijters, et al., 2010). The instrument followed the Maxim of Quantity Method which "directs those communicating to provide all relevant information but to avoid redundancy" and to provide no more/less information than needed (Dillman et al., 2003, p.5). The researchers recognized the respondents as individuals with sufficient background information about each of the questions and the main topic of the study. Thus, as recommended by Smyth, et al. (2006) and Weijters, et al. (2010), this work used both positive and negative statements in the questionnaire to prevent a failure to read each item.

The forced-choice certainty method prompted the respondent to choose an option among alternatives and assign a value to that response (i.e., 1-5). The number assigned to the provided stimuli does not assume an equal difference between response values. In essence, the forced-choice certainty method provided opportunities to respondents to agree/disagree and to express their opinion toward the middle or end of a continuum. Thus, those with polarized disagreements can express this more readily and intensely than typical Likert scale formats. The availability of an extra response category allowed respondents in this survey instrument to differentiate their responses from others through the expression of agreement/disagreement and level of certainty. It honors the call of Weijters, et al. (2010) who suggested researchers need to allow 
respondents the opportunity to provide variation without damaging the valences of success and failure. Thus, those agreeing with statements will vary on their certainty, but not toward their decision to agree. Interestingly, this set-up also allowed the use of standard deviations, chi-squares, and p-values to report statistical information. Chi-squares were included in this evaluation because they provide an association between proportions and p-values were used to show the difference between extreme responses.

The forced-choice certainty method further served to eliminate potential bias that might occur with simple forced-choice instruments because it did not guide respondents to a specific answer to which they may or may not be committed (Benzing \& Christ, 1997). In this study, each individual used the response scale with some sort of frame of reference or anchor point (i.e., personally or situationally determined). Also in this case, the response set demonstrated the individuals' response variability on the issue of the BCS arrangement and potential postseason alternatives. Koriat (2008) argued forced-choice questions are mediated by familiarity to the item in question and that familiarity and accessibility to items typically yield high correlations and confidence to selections.

Finally, we chose a non-probability convenience sample of student-athletes at the institution in spring 2009 because it acted as a powerful method to gather important information from a specific and generally difficult to recruit population (Gratton \& Jones, 2010). Gratton and Jones (2010) pointed out non-probability convenience samples appear suitable for exploratory research, which aims to generate new thoughts and perspectives on a phenomenon. Trochim and Donnelly (2007) and others also promoted the efficiency of nonprobability sampling through a convenience sample when the proportionality of a population is not a major concern and there is evident homogeneity within the group (Gratton \& Jones, 2010; Salant \& Dillman, 1994). Although generalization to all Division I FBS members is not likely permitted here, the high interconnectedness of many programs (e.g., coaches and players working/playing for or with other coaches and players) and strength of the football culture suggests many Division I FBS participants 
will similarly view this topic and thus the outcome presents a good base for future research endeavors on this topic.

\section{Results}

Respondents

Of the 79 football student-athlete respondents, 40 were juniors $(n=20)$ or seniors $(n=20)$, while 11 were freshman and 13 were sophomores (1 was a graduate student and 15 did not report their academic rank). The age of respondents ranged from 18 to 26, with a mean of $20.5(S D=1.41)$. The vast majority of the respondents were Caucasian $(n=38 ; 48.1 \%)$ and Black $(n=20 ; 25.3 \%)$. Fifteen did not report their ethnicity.

Findings

The survey instrument was broken into two sections. In the first section, respondents were asked whether they agree or disagree with a series of statements on BCS issues, including items on fairness, commercialization, academic/physical welfare, and format preference (see Table 1). 


\section{Table 1: Agreement/Disagreement and Certainty on Fairness, Commercialization, Academics, and Format Preference}

\begin{tabular}{|c|c|c|c|c|c|}
\hline & Agree & Certainty & Disagree & Certainty & Significance \\
\hline \multicolumn{6}{|l|}{ Fairness } \\
\hline $\begin{array}{l}\text { There is a problem with the BCS selection process } \\
\text { utilized by Division I (FBS) football to determine a } \\
\text { national champion. }\end{array}$ & $\begin{array}{c}54 \\
(69.2 \%)\end{array}$ & $\begin{array}{c}3.80 \\
(1.17)\end{array}$ & $\begin{array}{c}24 \\
(30.8 \%)\end{array}$ & $\begin{array}{c}3.33 \\
(1.20)\end{array}$ & .114 \\
\hline $\begin{array}{l}\text { The current BCS system produces a "true" } \\
\text { undisputed national champion. }\end{array}$ & $\begin{array}{c}18 \\
(22.8 \%)\end{array}$ & $\begin{array}{c}3.41 \\
(1.00)\end{array}$ & $\begin{array}{c}61 \\
(77.2 \%)\end{array}$ & $\begin{array}{c}3.72 \\
(1.21)\end{array}$ & .339 \\
\hline $\begin{array}{l}\text { The BCS selection process is equally fair to the } 11 \\
\text { Division I (FB S) football conferences. }\end{array}$ & $\begin{array}{c}24 \\
(30.4 \%)\end{array}$ & $\begin{array}{c}3.30 \\
(1.11)\end{array}$ & $\begin{array}{c}55 \\
(69.6 \%)\end{array}$ & $\begin{array}{c}3.78 \\
(1.03)\end{array}$ & .072 \\
\hline $\begin{array}{l}\text { Charter BCS institutions/ conferences (i.e., ACC, Big } \\
12, \text { Big East, Big Ten, SEC, Pac-10) enjoy a } \\
\text { favorable position on obtaining a BCS game versus } \\
\text { other institutions/conferences (i.e., non-charter BCS } \\
\text { like WAC, MAC, MWC, C-USA, and Sun B elt). }\end{array}$ & $\begin{array}{c}68 \\
(86.1 \%)\end{array}$ & $\begin{array}{c}3.78 \\
(1.26)\end{array}$ & $\begin{array}{c}11 \\
(13.9 \%)\end{array}$ & $\begin{array}{l}3.27 \\
(.79)\end{array}$ & .200 \\
\hline $\begin{array}{l}\text { Pre season and early season polls rankings do not } \\
\text { bias the non-charter conferences (WAC, Mountain } \\
\text { West, Sun Belt, Conference USA, MAC) from } \\
\text { equally obtaining/securing the opportunity to earn a } \\
\text { position in the BCS. }\end{array}$ & $\begin{array}{c}38 \\
(48.1 \%)\end{array}$ & $\begin{array}{c}3.39 \\
(1.13)\end{array}$ & $\begin{array}{c}41 \\
(51.9 \%)\end{array}$ & $\begin{array}{c}3.56 \\
(1.14)\end{array}$ & .517 \\
\hline $\begin{array}{l}\text { All } 120 \text { Division I (FBS) football te ams do not enjoy } \\
\text { a "real" chance to secure a BCS National Title Game } \\
\text { opportunity. }\end{array}$ & $\begin{array}{c}57 \\
(72.2 \%)\end{array}$ & $\begin{array}{c}4.02 \\
(1.18)\end{array}$ & $\begin{array}{c}22 \\
(27.8 \%)\end{array}$ & $\begin{array}{l}3.14 \\
(.73)\end{array}$ & $.002^{* *}$ \\
\hline $\begin{array}{l}\text { The traditional BCS schools are not more likely to } \\
\text { obtain most of the financial rewards associated with } \\
\text { BCS bowl participation. }\end{array}$ & $\begin{array}{c}27 \\
(34.2 \%)\end{array}$ & $\begin{array}{c}3.44 \\
(1.40)\end{array}$ & $\begin{array}{c}52 \\
(65.8 \%)\end{array}$ & $\begin{array}{c}3.34 \\
(1.12)\end{array}$ & .721 \\
\hline $\begin{array}{l}\text { Less controversy would exist if the selection } \\
\text { procedures used to choose the BCS participants were } \\
\text { similar to the NCAA men's basketball selection } \\
\text { process. }\end{array}$ & $\begin{array}{c}57 \\
(72.2 \%)\end{array}$ & $\begin{array}{c}3.42 \\
(1.21)\end{array}$ & $\begin{array}{c}22 \\
(27.8 \%)\end{array}$ & $\begin{array}{c}3.68 \\
(1.21)\end{array}$ & .393 \\
\hline
\end{tabular}




\begin{tabular}{|c|c|c|c|c|c|}
\hline \multicolumn{6}{|l|}{ Commercialization } \\
\hline $\begin{array}{l}\text { The current BCS system does not produce important, } \\
\text { intriguing, and quality match-ups. }\end{array}$ & $\begin{array}{c}13 \\
(165 \%)\end{array}$ & $\begin{array}{c}3.62 \\
(1.39)\end{array}$ & $\begin{array}{c}66 \\
(83.5 \%)\end{array}$ & $\begin{array}{c}3.65 \\
(1.10)\end{array}$ & 918 \\
\hline $\begin{array}{l}\text { I see great commercial appeal/possibilities associated } \\
\text { with an NCAA Division I (FBS) football to urnament. }\end{array}$ & $\begin{array}{c}65 \\
(823 \%)\end{array}$ & $\begin{array}{c}3.65 \\
(1.19)\end{array}$ & $\begin{array}{c}14 \\
(17.7 \%)\end{array}$ & $\begin{array}{c}3.43 \\
(1.34)\end{array}$ & .546 \\
\hline $\begin{array}{l}\text { I believe our school would enjoy an advantage } \\
\text { hosting a playoff game at our home site. }\end{array}$ & $\begin{array}{c}66 \\
(84.6 \%)\end{array}$ & $\begin{array}{c}4.03 \\
(1.15)\end{array}$ & $\begin{array}{c}12 \\
(15.4 \%)\end{array}$ & $\begin{array}{l}3.58 \\
(.90)\end{array}$ & .206 \\
\hline $\begin{array}{l}\text { I do not believe fans of my school team would travel } \\
\text { to an away site multiple weeks to follow our team in } \\
\text { a playoff format. }\end{array}$ & $\begin{array}{c}16 \\
(203 \%)\end{array}$ & $\begin{array}{c}3.38 \\
(1.26)\end{array}$ & $\begin{array}{c}63 \\
(79.7 \%)\end{array}$ & $\begin{array}{l}4.17 \\
(.99)\end{array}$ & $.008^{* * *}$ \\
\hline $\begin{array}{l}\text { I favor using current existing bowl sites for the } \\
\text { postseason playoff tournament. }\end{array}$ & $\begin{array}{c}51 \\
(64.6 \%)\end{array}$ & $\begin{array}{c}3.55 \\
(1.21)\end{array}$ & $\begin{array}{c}28 \\
(35.4 \%)\end{array}$ & $\begin{array}{c}3.50 \\
(1.29)\end{array}$ & .867 \\
\hline $\begin{array}{l}\text { Currently, there are 34-bowl games following the } \\
\text { conclusion of the football season. In addition to a } \\
\text { playofftournament, I believe most of these bowl } \\
\text { games could occur as scheduled. }\end{array}$ & $\begin{array}{c}55 \\
(69.6 \%)\end{array}$ & $\begin{array}{c}3.29 \\
(1.27)\end{array}$ & $\begin{array}{c}24 \\
(30.4 \%)\end{array}$ & $\begin{array}{c}3.38 \\
(1.31)\end{array}$ & .790 \\
\hline \multicolumn{6}{|l|}{ Academic } \\
\hline $\begin{array}{l}\text { As a student-athlete, I would worry about missing } \\
\text { class to participate in a playoff. }\end{array}$ & $\begin{array}{c}27 \\
(34.2 \%)\end{array}$ & $\begin{array}{c}3.44 \\
(1.34)\end{array}$ & $\begin{array}{c}52 \\
(65.8 \%)\end{array}$ & $\begin{array}{c}4.02 \\
(1.21)\end{array}$ & .058 \\
\hline $\begin{array}{l}\text { As a student-athlete, I would worry about taking } \\
\text { finals during the week of a playoff. }\end{array}$ & $\begin{array}{c}39 \\
(49.4 \%)\end{array}$ & $\begin{array}{c}3.59 \\
(1.21)\end{array}$ & $\begin{array}{c}40 \\
(50.6 \%)\end{array}$ & $\begin{array}{c}4.08 \\
(1.12)\end{array}$ & .068 \\
\hline $\begin{array}{l}\text { As a student-athlete, I could perform well in the } \\
\text { classroom and on finals during participation in a } \\
\text { playoff. }\end{array}$ & $\begin{array}{c}52 \\
(65.8 \%)\end{array}$ & $\begin{array}{c}3.50 \\
(1.31)\end{array}$ & $\begin{array}{c}27 \\
(34.2 \%)\end{array}$ & $\begin{array}{c}3.81 \\
(1.20)\end{array}$ & .317 \\
\hline $\begin{array}{l}\text { Regular season competition should revert back to an } \\
11 \text {-game season. }\end{array}$ & $\begin{array}{c}49 \\
(62.0 \%)\end{array}$ & $\begin{array}{c}3.49 \\
(1.33)\end{array}$ & $\begin{array}{c}30 \\
(38.0 \%)\end{array}$ & $\begin{array}{c}3.20 \\
(1.03)\end{array}$ & 310 \\
\hline
\end{tabular}


FBS Student-athlete perspective

\begin{tabular}{|c|c|c|c|c|c|}
\hline \multicolumn{6}{|l|}{ Format Preference } \\
\hline $\begin{array}{l}\text { The NCAA should organize the Division I (FB S) } \\
\text { national championship over a BCS title game. }\end{array}$ & $\begin{array}{c}54 \\
(68.4 \%)\end{array}$ & $\begin{array}{c}3.70 \\
(1.18)\end{array}$ & $\begin{array}{c}25 \\
(31.6 \%)\end{array}$ & $\begin{array}{c}3.28 \\
(1.37)\end{array}$ & .162 \\
\hline $\begin{array}{l}\text { Division I (FBS) football could utilize a playoff } \\
\text { system/structure similar to high school, } \\
\text { intercollegiate (Division I (FCS), I and III) and } \\
\text { professional football. }\end{array}$ & $\begin{array}{c}61 \\
(772 \%)\end{array}$ & $\begin{array}{c}3.98 \\
(1.22)\end{array}$ & $\begin{array}{c}18 \\
(22.8 \%)\end{array}$ & $\begin{array}{c}3.39 \\
(1.15)\end{array}$ & .069 \\
\hline $\begin{array}{l}\text { I prefer a football playoff in addition to the } \\
\text { current/established minor bowl games and as a } \\
\text { replacement for the } 10 \text {-team BCS bowl arrangement. }\end{array}$ & $\begin{array}{c}52 \\
(658 \%)\end{array}$ & $\begin{array}{c}3.73 \\
(1.22)\end{array}$ & $\begin{array}{c}27 \\
(34.2 \%)\end{array}$ & $\begin{array}{c}3.22 \\
(1.31)\end{array}$ & .091 \\
\hline $\begin{array}{l}\text { I prefer a playoff in addition to the current minor } \\
\text { bowl structure and the four B CS B owl games (i.e., } \\
\text { Pasadena-Rose Bowl, Miami-Orange Bowl, } \\
\text { Glendale- Fiesta Bowl, and New Orleans- Sugar } \\
\text { Bowl). }\end{array}$ & $\begin{array}{c}48 \\
(608 \%)\end{array}$ & $\begin{array}{c}3.60 \\
(1.16)\end{array}$ & $\begin{array}{c}31 \\
(39.2 \%)\end{array}$ & $\begin{array}{c}3.00 \\
(1.39)\end{array}$ & $.040^{*}$ \\
\hline $\begin{array}{l}\text { Home field advantage should be awarded to the } \\
\text { higher seeded (ranked) te am throughout the playoffs; } \\
\text { then, the national title game played at a neutral site? } \\
\text { Similar to Division I (FCS), II and II playoff } \\
\text { systems. }\end{array}$ & $\begin{array}{c}58 \\
(73.4 \%)\end{array}$ & $\begin{array}{c}3.67 \\
(1.24)\end{array}$ & $\begin{array}{c}21 \\
(26.6 \%)\end{array}$ & $\begin{array}{c}3.29 \\
(1.10)\end{array}$ & .221 \\
\hline $\begin{array}{l}\text { I prefer to host a playoff game as the higher seeded } \\
\text { team during the initial round(s) as a reward for my } \\
\text { team's regular season performance. }\end{array}$ & $\begin{array}{c}64 \\
(81.0 \%)\end{array}$ & $\begin{array}{c}3.70 \\
(1.18)\end{array}$ & $\begin{array}{c}15 \\
(19.0 \%)\end{array}$ & $\begin{array}{c}3.60 \\
(1.18)\end{array}$ & .761 \\
\hline $\begin{array}{l}\text { I would play in a bowl game following a } 1^{\text {st }} \text { round } \\
\text { loss in any playoff format, if that was available. }\end{array}$ & $\begin{array}{c}59 \\
(75.6 \%)\end{array}$ & $\begin{array}{c}3.57 \\
(1.33)\end{array}$ & $\begin{array}{c}19 \\
(24.4 \%)\end{array}$ & $\begin{array}{l}3.47 \\
(.96)\end{array}$ & .774 \\
\hline
\end{tabular}

Note: Significance denotes the difference in certainty between those who agree and those who disagree with each statement.

The second section included multiple choice items about specific preferences for post-season play in football (see Table 2). 
Table 2: Specific Preferences for Post-season Play

\begin{tabular}{|c|c|c|c|}
\hline & Choice & Certainty & Significance \\
\hline $\begin{array}{l}\text { I prefer the following type of playoff system/structure: } \\
\text { a. No playo ff } \\
\text { b. 4-team } \\
\text { c. 8-team } \\
\text { d. 12-team } \\
\text { e. 16-team }\end{array}$ & $\begin{array}{c}16(20.5 \%) \\
1(1.3 \%) \\
14(17.9 \%) \\
15(19.2 \%) \\
32(41.0 \%) \\
\end{array}$ & $\begin{array}{c}3.47(1.25) \\
3.00(.00) \\
4.29(1.14) \\
3.80(.68) \\
3.88(1.31) \\
\end{array}$ & 397 \\
\hline $\begin{array}{l}\text { Who should be responsible for organizing the postseason } \\
\text { toumament/playoff? } \\
\text { a. NCAA } \\
\text { b. BCS } \\
\text { c. Outside/Independent Selection Committee } \\
\text { d. None of the above }\end{array}$ & $\begin{array}{l}40(50.6 \%) \\
26(32.9 \%) \\
6(7.6 \%) \\
6(7.6 \%)\end{array}$ & $\begin{array}{l}3.73(1.20) \\
3.28(1.10) \\
3.67(.52) \\
3.17(1.84)\end{array}$ & .426 \\
\hline $\begin{array}{l}\text { Who should be responsible for selecting teams in a playoff? } \\
\text { a. NCAA } \\
\text { b. BCS } \\
\text { c. Outside/Independent Selection Committee } \\
\text { d. Fans/Spectators of College Fo otball } \\
\text { e. None of the above }\end{array}$ & $\begin{array}{c}42(53.2 \%) \\
25(31.6 \%) \\
5(6.3 \%) \\
1(1.3 \%) \\
5(6.3 \%) \\
\end{array}$ & $\begin{array}{l}3.49(1.12) \\
3.28(1.31) \\
4.20(.84) \\
2.00(.00) \\
3.4(1.67)\end{array}$ & .427 \\
\hline $\begin{array}{l}\text { Teams that qualify for the playoffs should be selected and } \\
\text { seeded (especially the "at-large" teams) for the tournament } \\
\text { by } \\
\text { a. NCAA Selection Committee } \\
\text { b. BCS Criteria/Finish }\end{array}$ & $\begin{array}{l}42(54.5 \%) \\
35(45.5 \%)\end{array}$ & $\begin{array}{l}3.59(1.16) \\
3.59(1.16)\end{array}$ & .976 \\
\hline $\begin{array}{l}\text { I prefer to play in: } \\
\text { a. BCS bowl game (non-title) } \\
\text { b. Playoff game }\end{array}$ & $\begin{array}{l}33(42.9 \%) \\
44(57.1 \%)\end{array}$ & $\begin{array}{l}3.63(1.16) \\
3.67(1.05)\end{array}$ & .872 \\
\hline $\begin{array}{l}\text { I prefer to play in: } \\
\text { a. NCAA Organized/Sponsored National Championship } \\
\text { b. BCS Title Game }\end{array}$ & $\begin{array}{l}34(44.7 \%) \\
42(55.3 \%)\end{array}$ & $\begin{array}{l}4.09(1.13) \\
3.66(1.18)\end{array}$ & .122 \\
\hline
\end{tabular}

Note: Significance denotes the difference in certainty between each group.

For both sections, respondents were also asked to indicate their level of certainty. The following information will unveil and explore the results for each aea.

Fairness. Overall, football student-athletes in this study questioned the fairness of the current BCS system. Specifically, a majority agreed that: 1) Charter BCS institutions/ conferences (e.g., ACC, Big 12, Big East, Big Ten, SEC, Pac-10) enjoy a favorable position on obtaining a BCS game versus other institutions/conferences (86.1\%): 2) All 120 Division I (FBS) football teams do not enjoy a "real" chance to secure a BCS National Title Game opportunity (72.2\%); 3) Less controversy would exist if the selection procedures used to choose the BCS participants were similar to the NCAA men's basketball selection process (72.2\%); 
and 4) There is a problem with the BCS selection process utilized by Division I FBS football to determine a national champion (69.2\%). Next, respondents disagreed with the statements: 1) The current BCS system produces a "true" undisputed national champion $(77.2 \%)$; 2) The BCS selection process is equally fair to the 11 Division I FBS football conferences (69.6\%); and 3) The traditional BCS schools are not more likely to obtain most of the financial rewards associated with BCS bowl participation (65.8\%). Finally, responses were mixed for the statement "Preseason and early season polls/rankings do not bias the non-charter conferences (Western Athletic, Mountain West, Sun Belt, Conference USA, Mid-American) from equally obtaining/securing the opportunity to earn a position in the BCS", with $48.1 \%(n=38)$ agreeing and $51.9 \%(n=41)$ disagreeing. Only one item ("All 120 Division I (FBS) football teams do not enjoy a "real" chance to secure a BCS National Title Game opportunity") produced a significant difference in certainty between those who agreed $(M=4.02 ; S D=1.18)$ and those who disagreed $(M=3.14$; $S D=.73), t(75)=-3.17, p=.002$.

Commercialization. Six items were included to assess the respondent's feelings on commercialization. A majority of them agreed with the following statements: 1) I believe our school would enjoy an advantage hosting a playoff game at our home site (84.6\%); 2) I see great commercial appeal/possibilities associated with an NCAA Division I (FBS) football tournament (82.3\%); 3) Currently, there are 34-bowl games following the conclusion of the football season. In addition to a playoff/tournament, I believe most of these bowl games could occur as scheduled (69.6\%); and 4) I favor using current existing bowl sites for the postseason playoff/tournament $(64.6 \%)$. Similarly, they disagreed with the following two negatively-worded statements: 1) The current BCS system does not produce important, intriguing, and quality match-ups (83.5\%); and 2) I do not believe fans of my school/team would travel to an away site multiple weeks to follow our team in a playoff format $(79.7 \%)$. That last statement was the only one that produced a significant difference in level of certainty between those who agreed 
$(M=3.38 ; S D=1.26)$ and those who disagreed $(M=4.17 ; S D=$ .99), $t(77)=2.72, p=.008$.

Academics/Physical Welfare. A majority of football studentathletes $(62 \%)$ in this study would like to see the regular season reduced back to 11 games. There were mixed opinions on taking final exams during the week if a playoff system was created, with 40 respondents $(50.6 \%)$ saying they would worry about their exams and $39(49.4 \%)$ saying they would not worry about them. However, 52 respondents $(65.8 \%)$ felt they could still perform well in the classroom and on finals during participation in a playoff. Finally, only 27 respondents $(34.2 \%)$ would worry about missing class to participate in a playoff. There were no significant differences in level of certainty between those who agreed and those who disagreed with the academic items.

Format Preference. In general, respondents would like to see a playoff in Division I FBS. Specifically, they agreed with the following statements: 1) Division I (FBS) football could utilize a playoff system/structure similar to high school, intercollegiate (Division I (FCS), II and III) and professional football (77.2\%); 2) The NCAA should organize the Division I (FBS) national championship over a BCS title game $(68.4 \%)$; 3) I prefer a football playoff in addition to the current/established minor bowl games and as a replacement for the 10-team BCS bowl arrangement (65.8\%); and 4) I prefer a playoff in addition to the current minor bowl structure and the four BCS Bowl games (60.8\%). Respondents also strongly agreed with two items regarding home field advantage in the playoffs: 1) I prefer to host a playoff game as the higher seeded team during the initial round(s) as a reward for my team's regular season performance ( $81 \%$ ); and 2) Home field advantage should be awarded to the higher seeded (ranked) team throughout the playoffs; then, the national title game played at a neutral site $(73.4 \%)$. Interestingly, 59 respondents $(75.6 \%)$ said they would play in a bowl game following a 1st round loss in a playoff format (if that was available). Respondents who agreed $(M=3.60 ; S D=1.09)$ with the statement "I prefer a playoff in addition to the current minor bowl 
structure and the four BCS Bowl games" were significantly more certain than those who disagreed $(M=3.00 ; S D=1.39), t(77)=-$ $2.01, p=.04$.

Specific Preferences for Post-Season Play. Only 16 (20.5\%) of the respondents did not support a playoff system for Division I FBS football. Of the remaining 62 respondents, 32 of them preferred a 16-team playoff. Interestingly, only one respondent preferred a four team playoff, a system that many stakeholder groups proposed throughout the history of this debate and has been recently promoted within the BCS ("BCS takes big step," 2012; Seifried, 2011, 2012). Additionally, 44 respondents $(57.1 \%)$ preferred playing in a playoff game (as opposed to a non-title BCS game). However, when given the choice of playing in an NCAA organized/sponsored National Championship playoff or the BCS National Championship Game, a slight majority $(n=42 ; 55.3 \%)$ chose the latter. Finally, while the NCAA is not currently involved with post-season play at the FBS level, nor part of the BCS proposal, just over half of the respondents ( $n=40 ; 50.6 \%$ ) felt they should be responsible for organizing the post-season tournament/playoff and $42(53.2 \%)$ felt they should be responsible for selecting the participating teams.

\section{Differences by Academic Rank and Race. Those reporting} their academic rank included 11 freshmen, seven sophomores, 20 juniors, and 20 seniors. Because there was only one graduate student, responses from this respondent were dropped from these analyses. Regarding race, since $60.3 \%(n=38)$ of the 63 respondents who reported their ethnicity were Caucasian, $31.7 \%$ ( $n$ $=20)$ were Black, and only 7.9\% $(n=5)$ were Asian-American, Hispanic, Native-American, or other, it was decided to dichotomize this variable (i.e., White/non-White).

There were three items where respondents differed significantly with regard to academic rank. The largest difference based on rank was the item "I believe our school would enjoy an advantage hosting a playoff game at our home site", $\chi 2(4)=12.10, p$ 
$=.017$. All 20 seniors agreed with this statement, while only $63.6 \%$ $(n=7)$ of the freshmen agreed. Similarly, 63.6\% $(n=7)$ of the freshmen and $69.2 \%(n=9)$ of the sophomores disagreed with the statement "I do not believe fans of my school/team would travel to an away site multiple weeks to follow our team in a playoff format", while $95 \%(n=19)$ of the seniors and $90 \%(n=18)$ of the juniors disagreed, $\chi 2(4)=11.43, p=.022$. Finally, there was a significant difference in the preference for playing in a non-title BCS bowl game or a playoff game, $\chi 2(4)=10.11, p=.039$. Eighty-five percent $(n=17)$ of the seniors preferred playing in a playoff game, while freshmen $(n=6 ; 54.5 \%)$, sophomores $(n=7 ; 58.3 \%)$, and juniors $(n$ $=11 ; 55 \%)$ all preferred playing in a non-title BCS bowl game.

White and non-White football student-athlete respondents differed on four items in the study. The largest difference was in the item "I do not believe fans of my school/team would travel to an away site multiple weeks to follow our team in a playoff format", $\chi^{2}(1)=9.89, p=.002$. All but 2 of the White respondents $(n=36$; $94.7 \%)$ disagreed with the statement, while $64 \%(n=16)$ of the Non-Whites disagreed. There was also a significant disagreement for the item "The BCS selection process is equally fair to the 11 Division I (FBS) football conferences", $\chi^{2}(1)=4.83, p=.028$. Both groups disagreed with the statement, but a significantly higher percentage of White respondents $(n=31 ; 81.6 \%)$ disagreed than non-Whites ( $n=14 ; 56 \%)$. Additionally, a significantly higher percentage of White respondents $(n=35 ; 92.1 \%)$ agreed with the statement "I believe our school would enjoy an advantage hosting a playoff game at our home site" than non-White respondents $(n=18$; $72 \%), \chi^{2}(1)=4.57, p=.033$. Finally, there was a significant difference for the item "The current BCS system does not produce important, intriguing, and quality match-ups", $\chi^{2}(1)=4.51, p=.034$. Again, both groups disagreed with this statement, but non-White respondents $(n=17 ; 68 \%)$ did so at a significantly lower rate than White respondents $(n=34 ; 89.5 \%)$. 


\section{Discussion/Conclusion}

This forced-choice certainty method research endeavor uniquely investigated the perspectives of Division I FBS studentathletes related to the BCS and playoff debate currently raging. The four main components of this effort focused on fairness, commercialization, academic/physical welfare, and format preference as they were generally the most recognized issues in previous debates held by other important stakeholder groups of college football (Oriard, 2009; Seifried, 2011, 2012; Seifried \& Smith, 2011). First, the football student-athletes surveyed generally questioned the fundamental fairness of the current BCS system with a high level of certainty. This follows similar results produced by Seifried and Smith (2011) and Seifried (2011, 2012) who demonstrated that many congressional leaders, coaches, administrators, and fan nations also questioned the legitimacy of the current BCS agreement versus other alternative postseason formats. As an example, Senators and Representatives expressed their concern with the current postseason arrangement by acknowledging a better way to establish a National Champion and to ensure equality and/or equity (i.e., fundamental fairness) for all Division I FBS participants must exist. Specifically, Senators Joe Biden (DemocratDelaware) and Orrin Hatch (Republican- Utah) noted the "principle of fairness" was violated because non-BCS schools, in particular, did not enjoy a realistic shot to play for the national championship ("BCS or Bust," 2003, p. 3). They also expressed non-BCS schools experienced tremendous difficulty just getting a bid to BCS contests that their BCS-charter peers did not have to endure.

Representative Cliff Stearns (Republican- Florida) identified the computer rankings, coaches polls, and conference schedules as part of a "fuzzy" calculation system, which regularly eliminated deserving BCS and non-BCS schools from the title game and BCS contests ("Determining a champion," 2005, p.2). Craig Thompson (Commissioner- Mountain West Conference) offered similar criticism regarding the BCS ranking system and the selection criteria/process all schools must endure to secure a BCS bid ("Hearings on BCS," 2009). Questions about the reputational 
legitimacy of the BCS as the best method to discover a national champion also emerged previously from Sandbrook (2004). Overall, six computer rankings, the USA Today/ESPN coaches' poll, and Harris poll each represent one-third of the collective BCS ranking system.

Again, in this study, a vast majority of the participating student-athletes strongly suggested the current BCS model did not produce a "true" undisputed champion, provided a favorable position to BCS-charter members to secure financial rewards and postseason opportunities, and believed that less controversy would exist under a different selection process. Procedures similar to those used by the NCAA men's basketball selection process were accepted by the survey participants as one method to produce less controversy. Craig Thompson agreed with this notion at a 2009 Congressional hearing by arguing for a national tournament that used performance-based standards to select and seed teams ("Hearing on BCS," 2009). Thompson, former chair of the NCAA Division I Men's Basketball Committee in 1999, positioned the football selection committee for Division I FBS, like the NCAA uses for the basketball tournament, as possible and necessary to help identify a champion based on results. Thompson suggested the NCAA selection committee idea presented the Division I FBS with a good model because it assured representation in the tournament would be based on merit, not popularity which the BCS bowls admittedly used to offer many of their bids ("BCS Media Guide," 2011).

It should be noted that currently the NCAA does not manage the Division I bowl system but simply certifies their location to host ("BCS Media Guide," 2011). The BCS was created through an alliance between bowl game organizers/committees, automatic qualifying institutions, and television networks to form the premier bowl event which also includes a national championship contest ("BCS Media Guide," 2011). However, the NCAA sponsors and manages several other football championship events at the Division I FCS, II, and III levels which utilize similar selection processes to the basketball tournament. Thus, the idea that the NCAA could create a playoff bracket and manage that event is not incredible or 
logistically impossible as some opponents of a national tournament suggested.

With great certainty, survey respondents overwhelmingly supported a playoff over the BCS and that the NCAA could utilize a format similar to high school, intercollegiate (Division I FCS, II and III) and professional football organizations to produce a national tournament. The 8,12, and 16-team formats were all preferred over the 4-team format with the 16-team emerging as the most preferred by participants. The mean score of all playoff preferences also received significant certainty from respondents. Again, previous literature showed similar results. For instance, Seifried's (2011, 2012) historical analysis of administrative stakeholder perspectives (e.g., presidents, commissioners, athletic directors) and coaches on alternative postseason formats from the 1960s through the 1990s showed the 4, 8, and 16-team playoff as the most commonly supported. Seifried and Smith's (2011) content analysis on congressional hearing transcripts also demonstrated that multiple game formats such as the 8 and 16-team playoff gained significant support. As an example, the 8-team playoff format generated significant debate after Craig Thompson pitched the idea in April 2009.

Interestingly, the survey respondents preferred playing in a playoff to a non-title BCS game, thus supporting earlier indications that they would rather settle claims for number one on the field. The participants also indicated they would enjoy and accept the opportunity to go to a bowl game and participate in those traditions if they got eliminated from a playoff. This, along with their strong belief that most bowl game traditions could survive the introduction of a playoff, suggests to administrators that their worries related to missed fundraising opportunities, commonly associated bowl participation, could be reduced because those bowl games would still be glorified exhibition events like they are today (Seifried, 2011, 2012). The interest that student-athletes demonstrated in preserving the bowl system along with their confidence in the bowls and playoff coexisting matches the thoughts of other important stakeholders who also argued that the bowls may need to adapt to future conditions to 
survive (Seifried, 2011, 2012; Seifried \& Smith, 2011). As an example, John Junker (Former Chief Executive Officer and President- Fiesta Bowl) stated during a 2005 congressional hearing that he felt his business (i.e., bowls) would need to respond to

market preferences of the college football fan nation to continue survival ("Determining a champion," 2005). Specifically, Junker acknowledged the bowls may not be the best postseason arrangement to service fan preferences or maximize commercial outcomes.

The student-athletes also presented stimulating results on the logistical arrangement of the playoff. For example, Schwenk's (2000) axioms of delayed confrontation and sincerity rewarded are respected by survey participants through their strong preference for home field advantage being awarded to the higher seeded teams as a reward for regular season performance. Seniors and juniors more frequently and confidently agreed this arrangement would provide their team with an advantage than freshman and sophomores. This difference may be due to the fact that freshman and sophomores are generally lower on the depth chart and thus likely do not play as much as seniors and juniors. The lack of playing time could lead them to be less influenced by the crowd and home field conditions than their peers.

Another rather interesting result from this study discovered, despite their preferences for a playoff, a slight majority of studentathletes would prefer playing in a BCS National Championship Game over a NCAA organized/sponsored national tournament and seniors differed greatly from all others in the acceptance of a playoff game over a non-title BCS game appearance. There could be several reasons for these finding. For example, student-athletes are typically rewarded with a 'swag' bag which includes a variety of unique gifts for their bowl participation. The NCAA allows student-athletes to receive gifts up to $\$ 500$ from the various bowl games in addition to another $\$ 350$ worth of items from their home conferences for bowl participation. Thus, it is possible that student-athletes prefer the BCS National Title Game simply because they want these items and know 
they would not receive such items for participation in an NCAA managed event. Non-seniors would likely prefer the non-BCS bowl bid simply to acquire stuff rather than mark out their legacy. Seniors from the participating institution also enjoyed involvement in BCS games for a majority of their career, thus they may have acquired many of the items typically offered by those bowl brands.

Non-seniors may also differ from seniors for academic and physical reasons. For instance, as they approach the end of their academic career, seniors generally take courses more applicable to their career interests; furthermore they learned the skills necessary for them to complete courses and better manager their classes. They also likely developed better study, eating, and workout habits than their underclass counterparts through the help of student-athlete academic services, athletic training, and strength and conditioning coaches. Thus, seniors should be less hesitant about participating in a playoff simply because they are better prepared to succeed in the classroom and understand how to maintain their physical health. Seniors may be less vulnerable to outside distractions that may affect their commitment to college and the attention their body requires. Again, although roughly half of the participants indicated they would worry about taking final exams in a playoff system, almost twothirds of the total respondents suggested they felt like they would perform well in the classroom during the stretch run of a semester/quarter and pass their final exams. This information suggests that seniors significantly impacted the outcome of this question and further suggests student-athlete academic services departments will be critical to help student-athletes survive and flourish in a national tournament.

Academically, missing class did not emerge as a major concern for most respondents but the physical impact of that possible event was noted. We suspect this response likely surfaced because football players generally miss the least amount of playing time already among NCAA sports and any acceptable playoff scenario would probably take place during weekend days and during the holiday season when classes do not meet. Overall, the academic welfare component of many anti-playoff arguments may be defeated 
through this work. For further information on student-athlete academic services effectiveness we recommend Adler (2008), Martin, Harrison, Stone, and Lawrence (2010), and Steiner (2010).

Besides academic and physical confidence, the survey respondents also finally indicated they felt confident in the great commercial appeal/possibilities that would be produced and associated with the establishment of an NCAA Division I FBS football tournament. This notion that the playoff would be respected and popular among the various college football fan nations can also be seen through the comments of John Sandbrook and Representative Lee Terry who suggested that the BCS system left out deserving teams who could play well in front of a national audience ("Determining a champion," 2005; Sandbrook, 2004).

Student-athletes in this survey overwhelmingly acknowledged the BCS produced intriguing and quality match-ups with great confidence, but again the sum of this work demonstrated they also believe a national tournament would create a greater spectacle which they anticipate would be greatly consumed by the various college football fan nations. Respondents supported this position by strongly indicating that they believe their fans would travel to away sites over multiple weeks to follow their team. The strength of the belief should be taken seriously because football student-athletes are frequently privy to the pulse of their fan nation and understand the strength of their commitment.

James Duderstadt (President of the University of Michigan from 1987 to 1996) also indicated a possible 16-team playoff could easily produce an estimated $\$ 3$ to $\$ 4$ billion over several years to support the idea that a playoff would be a commercial success and that fans would travel under a multiple-game format (Duderstadt, 2003). Jim Delany (Commissioner- Big Ten Conference) and John Swofford (Commissioner- ACC) also accepted that point on several occasions ("Competition in college," 2003; "Determining a champion," 2005; "Bowl Championship Series," 2009). Several others also argued for this point because the BCS bowl games increasing produced lower television ratings in recent years 
(Seifried, 2011, 2012; Seifried \& Smith, 2011). In essence, they, like student-athletes, recognized college football consumers desire more.

Finally, this work supported the forced-choice certainty method as a survey device to obtain the true perspective of individuals on an issue of public debate. For example, as a group generally ignored by the producers of college sport, speculation regarding the possible negative academic and physical impact of an alternative postseason format has been regularly supported by BCS advocates. This study indicated student-athletes feel confident they would perform well under a multi-game playoff format during finals and the stretch run of their academic quarter/semester. Preference for a larger playoff format (i.e., greater than 4) emerged to support this position and that student-athletes, like the general population, want to settle who is best on the field through an arrangement which included all qualified institutions, not just a privileged few. Studentathletes also importantly communicated that they felt their fans would enjoy a multi-game playoff format. Furthermore, they believed their fans would travel under to watch them play. This indicates consumer confidence in a playoff, from their perspective, is strong and that a playoff would be commercially attractive at the gate as well as with television. This study also communicated that respect for the bowl system is still strong but this may be due more to the gifts provided than concerns for physical or academic wellbeing. Overall, the forced-choice certain method appeared to encourage cognitive attention to questions and thus appeared to reduce confirmation bias because deeper consideration on every item discouraged satisficing. Furthermore, we advocate it as a method researchers should use to further explore the collective opinions on the topic by student-athletes of Division IFBS and other research questions which present comparative considerations. 


\section{References}

Adler, H. (2008). Development of an academic advising program for student-athletes at the Division III level. (Master's Thesis, Rowan University, 2008).

Bargagliotti, A. \& Li, L. (2009). Rating system design:

Transforming individual preferences to rating scores.

Working paper, Louisville College of Business No. 2008-07, Louisville. BCS or bust: Competitive and economic effects of the BCS on and off the field: Hearing before the Committee on the Judiciary, Senate. 108d Cong. 1st Sess. (2003)

BCS Media Guide 2011-2012 (2011). Bowl Championship Series Football. Retrieved from:

http://espn.go.com/i/ncf/bcs/2011BCSGuide2.pdf

BCS takes big step toward change, recommends four-team playoff (2012, April 26). Associated Press, Retrieved from: http://sportsillustrated.cnn.com/2012/football/ncaa/04/26/bcsmeetings-four-team.ap/index.html

Benzing, C. \& Christ, P. (1997). A survey of teaching methods among economics faculty. The Journal of Economic Education, 28(2), 182-188.

The Bowl Championship Series: Money and issues of fairness at publicly financed universities (2009, May 1). House of Representatives, Subcommittee on Commerce, Trade, and Consumer Protection, Washington, D.C. Retrieved from: http://energycommerce.house.gov/Press_111/20090501/trans cript_20090501_ct.pdf

Buchman, S. \& Kadane, J. B. (2008). Reweighting the Bowl Championship Series. Journal of Quantitative Analysis in Sports, 4(3), Article 2.Cieslak, T.J. (2005). A simple solution for a complicated problem: A 16-team playoff system for NCAA Division I-A football. (pp. 50-68) International Conference of Sport and Entertainment Business Program, University of South Carolina, November 2005. 
College football playoff confidential (2010, August 10). ESPN: The Magazine, Retrieved from:

http://sports.espn.go.com/ncf/news/story?id=5452896

Committee opposes football playoff for Division I-A (1993). The NCAA News, 30(18), 5.

Competition in college athletic conferences and antitrust aspects of the BCS: Hearing before Committee on the Judiciary, Senate. 108d Cong. 1st Sess. (2003).

Determining a champion on the field: A comprehensive review of the BCS and postseason college football: Hearing before Subcommittee on Commerce, Trade, and Consumer Protection, House of Representatives. 109d Cong. 1st Sess. (2005).

Dillman, D. A., Smyth, J. D., Christian, L. M. \& Stern, M. J. (2003). Multiple answer questions in self-administered surveys: The use of check-all-that-apply and forced-choice question formats. Paper presented at the American Statistical Association Annual Meeting, San Francisco.

Duderstadt, J. J. (2003). Intercollegiate athletics and the American university: A university president's perspective. Ann Arbor, MI: University of Michigan Press.

Gill, M. J., Swann, W. B., Jr., \& Silvera, D. H. (1998). On the genesis of confidence. Journal of Personality and Social Psychology, 75, 1101-1114.

Goldsmith, M. \& Koriat, A. (2008). The strategic regulation of memory accuracy and informativeness. In A.S. Benjamin and B.H. Ross (Eds.), The psychology of learning and motivation (Vol. 48, pp. 1-60). Amsterdam: Academic Press.

Gratton, C. \& Jones, I. (2010). Research methods for sport studies (2nd edition). New York: Routledge.

Greenleaf, E. A., Bickart, B., \& Yorkston, E. A. (1999). How response styles weaken correlations from rating scale surveys. Working paper, Stern School of Business, New York.

Hall, C. C., Ariss, L., \& Todorov, A. (2007). The illusion of knowledge: When more information reduces accuracy and 
increases confidence. Organizational Behavior \& Human Decision Processes, 103, 277-290.

Hearing on Bowl Championship Series: Is it fair and in compliance with antitrust law? (2009, July 7). Senate, Subcommittee on Antitrust, Competition Policy and Consumer Rights, Washington, D.C. Retrieved from: http://judiciary.senate.gov/hearings/hearing.cfm?id=3951 Koriat, A. (2008). When confidence in a choice is independent of which choice is made. Psychonomic Bulletin, 15(5), 9971001 .

Koriat, A., Nussinson, R, Bless, H., Shaked, N. (2008). Informationbased and experienced-based metacognitive judgments: Evidence from subjective confidence. In J. Dunlosky \& R.A. Bjork (Eds.), Handbook of memory and metamemory (pp. 117-135). Mahwah, NJ: Erlbaum.

Martin, B. E., Harrison, C. K., Stone, J., \& Lawrence, S. M. (2010). Athletic voices and academic victories: African American male student-athlete experiences in the Pac-Ten. Journal of Sport and Social Issues, 34(2), 131-153.

McCarty, J. A. \& Shrum, L. J. (2000). The measurement of personal values in survey research: A test of alternative rating procedures. Public Opinion Quarterly, 64(3), 271-298. The National Collegiate Athletic Association (2010, April 10). BCS Five-year summary revenue distribution. Retrieved from NCAA Postseason Football Finances Report website: http://www.ncaa.org/

Oriard, M. (2009). Bowled over: Big-time college football from the sixties to the BCS era. Chapel Hill, NC: The University of North Carolina Press.

Rossiter, J. R. (2002). The C-OAR-SE procedure for scale development in marketing. International Journal of Research in Marketing, 19(4), 305-335.

Salant, P. \& Dillman, D. A. (1994). How to conduct your own survey. New York: John Wiley \& Sons, Inc. 
Sandbrook, J. (2004). Division I-A postseason football history and status. Miami: The Knight Foundation Commission on Intercollegiate Athletics.

Schwenk, A. J. (2000). What is the correct way to seed a knockout tournament? The American Mathematical Monthly, 107(2), 140-150.

Seifried, C. S. (2011). The Opinions of Administrators on the Division I (Football Bowl Subdivision) Playoff Issue: A Content Analysis of their Perspectives Pre-BCS from Popular Media Sources and the NCAA News. Sport History Review, 42(1), 29-55.

Seifried, C. S. (2012). A historical review of the Division I (Football Bowl Subdivision) playoff issue pre-BCS: A content analysis of the core stakeholder perspectives from popular media sources and the NCAA News. Journal of Issues in Intercollegiate Athletics, 5, 96-118.

Seifried, C. S., \& Smith, T. (2011). Congressional hearings and the Division I (Football Bowl Subdivision) postseason arrangement: A content analysis on letters and testimonies. Journal of Issues in Intercollegiate Athletics, 4, 1-23.

Sharma, S. \& Weathers D. (2003). Assessing generalizability of scales used in cross-national research. International Journal of Research in Marketing, 20(1), 287-295.

Smith, R. A. (2001). Play-by-play: Radio, television, and big time college sport. Baltimore, MD: Johns Hopkins University Press.

Smyth, J. D., Dillman, D. A., Christian, L. M., \& Stern, M. J. (2006). Comparing check-all and forced-choice question formats in web surveys. Public Opinion Quarterly, 70(1), 66-77.

Southall, R. M., Southall, C., \& Dwyer, B. (2009). 2009 Bowl Championship Series telecasts: Expressions of big-time college sport's commercial institutional logistics, Journal of Issues in Intercollegiate Athletics, 2, 150-176.

Steiner, D. D. (2010). Coping with the demands of being a collegiate student-athlete: An exploratory investigation coupled with a set of procedural guidelines for athletic department personnel 
and related services. (Doctoral Dissertation, Rutgers University, 2010).

Stern, H. S. (2004) Statistics and the college football championship. The American Statistician, 58(3), 179-185.

Strizhakova, Y., Coulter, R. A., \& Price, L. L. (2008). The meanings of branded products: A cross-national scale development and meaning assessment. International Journal of Research in Marketing, 25(2), 82-93.

Student-athletes voice opinions on football playoff (1994). The NCAA News, 31(12), 1, 16.

Sudman, S., Bradburn, N. M., \& Schwarz, N. (1996). Thinking about answers: The application of cognitive processes to survey methodologies. San Francisco: Jossey Bass.

Trochim, W. T. \& Donnelly, J. P. (2007). The research methods knowledge base (3rd edition). Mason, OH: Atomic Dog.

Warren, R. Klonglan, G. E., \& Sabri, M. M. (1969). The certainty method: Its application and usefulness in developing empirical measures in social sciences. Rural Sociology Report No. 82. Ames, IA: Iowa State University.

Weijters, B. Cabooter, E., \& Schillewaert, N. (2010). The effect of rating scale format on response styles: The number of response categories and response category labels. International Journal of Research in Marketing, 27(3), 236- 2 


\section{About The Journal of SPORT}

The Journal of SPORT brings together in one journal the wide variety of research disciplines in sport and will be published biannually in July and February. The Journal of SPORT is published by the Center for Sport and Recreation Development at Kent State University. A faculty Advisory Board composed of nationally, as well as internationally recognized faculty participates in the peer mentorship review process. This unique, but distinctive, mentorship process provides opportunities for graduate students, at an array of institutions, to thoroughly analyze and review research in conjunction with a faculty mentor. The number of articles accepted will be limited through a selective review process. After the faculty mentored peer review is completed a final determination is made to accept or reject the article. The Journal of SPORT encourages faculty and/or students to submit their research for review.

\section{Submission Guidelines}

See www.thejournalofsport.com for Submission Guidelines. 